\title{
LEVANTAMENTO EXPLORATÓRIO DA PRODUÇÃO, COMPOSIÇÃO E PERFIL DE ÁCIDOS GRAXOS DO LEITE DE BÚFALAS EM CINCO FAZENDAS DO ESTADO DE SÃO PAULO
}

\author{
SÉRGIO AUGUSTO DE ALBUQUERQUE FERNANDES
}

Tese apresentada à Escola Superior de Agricultura

"Luiz de Queiroz", Universidade de São Paulo, para obtenção de título de Doutor em Agronomia, Área de Concentração: Ciência Animal e Pastagens.

PIRACICABA

Estado de São Paulo - Brasil

Julho - 2004 


\section{LEVANTAMENTO EXPLORATÓRIO DA PRODUÇÃO, COMPOSIÇÃO E PERFIL DE ÁCIDOS GRAXOS DO LEITE DE BÚFALAS EM CINCO FAZENDAS DO ESTADO DE SÃO PAULO}

SÉRGIO AUGUSTO DE ALBUQUERQUE FERNANDES

Zootecnista

Orientador: Prof. Dr. WILSON ROBERTO SOARES MATTOS

Tese apresentada à Escola Superior de Agricultura

"Luiz de Queiroz", Universidade de São Paulo, para obtenção de título de Doutor em Agronomia, Área de Concentração: Ciência Animal e Pastagens.

PIRACICABA

Estado de São Paulo - Brasil

Julho - 2004 
Dados Internacionais de Catalogação na Publicação (CIP)
DIVISÃO DE BIBLIOTECA E DOCUMENTAÇÃO - ESALQ/USP

Fernandes, Sérgio Augusto de Albuquerque

Levantamento exploratório da produção, composição e perfil de ácidos graxos do leite de búfalas em cinco fazendas do Estado de São Paulo / Sérgio Augusto de Albuquerque Fernandes. - - Piracicaba, 2004.

$84 \mathrm{p}$.

Tese (doutorado) - - Escola Superior de Agricultura Luiz de Queiroz, 2004.

Bibliografia.

1. Composição de alimentos 2. Dieta animal 3. Leite de búfala 4. Teor de gordura I. Título

CDD 636.293 
À Aldeci de Albuquerque Fernandes, minha mãe;

À Eça da Rocha Fernandes, meu pai;

À Gabriel, Beatriz e Thaís, meus filhos,

Dedico! 


\section{AGRADECIMENTOS}

Sem dúvida, essa é uma das partes mais importantes nesse trabalho, pois foram muitas contribuições que recebi para cumprir esta meta tão importante na minha vida.

A ordem de agradecimentos não indica maior ou menor importância da contribuição, mas apenas a cronologia, visto que sem a ajuda, apoio e incentivo de qualquer um destes colaboradores o percurso teria sido mais difícil.

Meus pais sempre me incentivaram e torceram para que eu buscasse 0 aperfeiçoamento profissional, talvez, como única forma de tentar galgar alguns degraus na sociedade excludente em que vivemos. Hoje sei que sou fonte de orgulho para eles, pois não é fácil ser nascido em uma região (Nordeste) que enfrenta tantas dificuldades sociais e chegar a Universidade de São Paulo, na Escola Superior de Agricultura "Luiz de Queiroz", que tanto orgulha o Brasil, para fazer um curso de pós-graduação. Papai e Mamãe, amo vocês.

Aos meus filhos Thaís, Gabriel e Beatriz, apenas pelo fato de existirem, o que deu outro sentido a minha vida, tornando-a mais alegre e leve. Amo muito vocês!

À Luciana Freitas, pelo incentivo para realizar os cursos de pósgraduação e pelos filhos que me deu.

Aos meus amigos e colegas da Universidade Estadual do Sudoeste da Bahia (UESB), pelo incentivo que me deram para fazer o doutorado e a UESB por todo o apoio que recebi. 
Aos amigos Alexandre Mello e Henrique Rocha pela amizade que sempre tiveram e por terem aberto a possibilidade de fazer o doutorado na ESALQ.

À pessoa maravilhosa do Prof. Wilson Mattos, que desde o primeiro contato me recebeu com gentileza e por ter me dado a oportunidade de ser orientado por ele, o que muito me orgulha.

À ESALQ pela oportunidade de fazer o Doutorado nesta renomada instituição.

Aos professores Humberto Tonhati (UNESP/Jaboticabal), Paulo Machado (ESALQ/USP), Dante Pazzanese Lanna (ESALQ/USP) e Gilberto Casadei de Baptista (ESALQ/USP) pelos ensinamentos e colaboração na realização do experimento.

À Tuka, Ana Paula e Adriana Bagaldo, pelo apoio e sem dúvida, pela alegria e carinho que sempre me trataram, sentirei saudade de vocês.

Aos amigos do LNCA, especialmente a Marco Antônio Sundfeld que pensou e executou este experimento comigo desde o início.

Aos amigos da pós-graduação: Michelle Nascimento, Daniele Loures e Raul Santin, Luciana Gerdes e Renato Roverate, Fábio Prudêncio, Liris Kindlein, Adriana Bagaldo, Daniel Sarmento, Narson Lima, Aelson Brum, André Souza, às Pittboas, etc., etc. Devo ter esquecido de algumas pessoas, mas isso não quer dizer que não tenham tido importância para mim.

À toda a equipe da Clínica do Leite.

À todo o pessoal da biblioteca, que sempre esteve à nossa disposição com o máximo de profissionalismo.

À Luiz Trevisan (Malagueta), Ricardo Cassamassino (Coró) e André Franco (Mineirinho) pelo apoio técnico na cromatografia e claro pela amizade, essencial nas dificuldades.

À Soraia Matarazzo, que tem me acompanhado no dia-a-dia dos últimos anos, pela paciência e dedicação. Você é muito especial! 


\section{SUMÁRIO}

Página

LISTA DE FIGURAS .............................................................................. viii

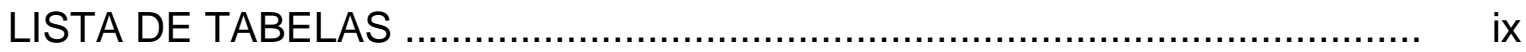

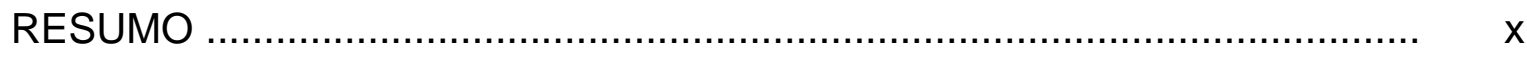

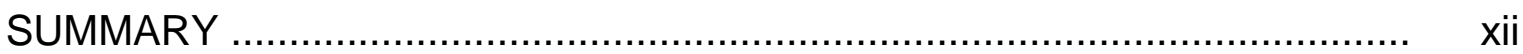

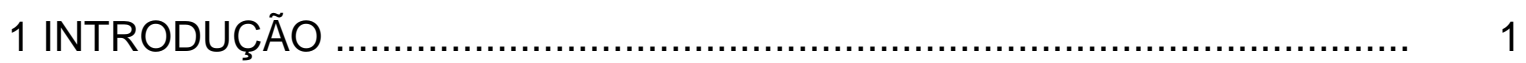

2 REVISÃO DE LITERATURA …..................................................... 3

2.1 Composição do leite........................................................................ 3

2.2 Natureza dos lipídeos....................................................................... 7

2.3 Os lipídeos nos alimentos de ruminantes............................................. 9

2.4 Os lipídeos no leite de bovídeos............................................................ 14

2.5 Ácido linoléico conjugado (CLA).................................................... 15

2.5.1 O CLA na saúde humana.............................................................. 16

2.5.2 O CLA em bovídeos................................................................... 17

2.5.2.1 Síntese de CLA no organismo animal............................................. 18

2.5.2.1.1 Biohidrogenação ruminal....................................................... 18

2.5.2.1.2 Biossíntese em tecidos animais.................................................. 22

2.6 Fatores dietéticos ligados à produção de CLA em ruminantes................. 23

2.7 Produção de CLA no leite de búfalas...................................................... 25

3 MATERIAL E MÉTODOS …............................................................ 26

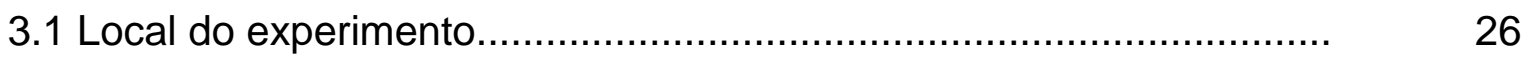

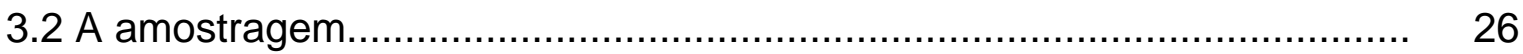

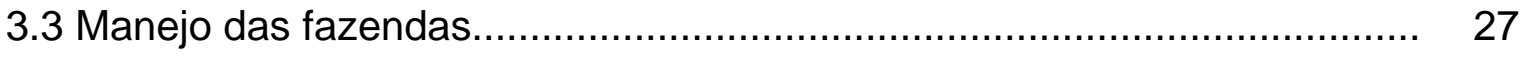


3.4 Procedimentos laboratoriais e parâmetros avaliados ............................. 28

3.5 Análise estatística....................................................................... 30

4 RESULTADOS E DISCUSSÃO 32

4.2 Componentes do leite ............................................................... 32

4.1.1 Teor de gordura no leite......................................................... 32

4.1.2 Teor de proteína no leite.............................................................. 33

4.1.3 Teor de $\mathrm{N}$ uréico no leite........................................................... 34

4.1.4 Teor de sólidos totais........................................................................ 37

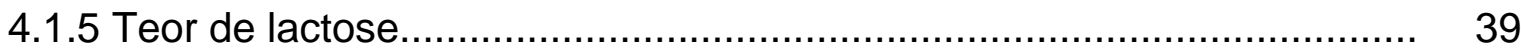

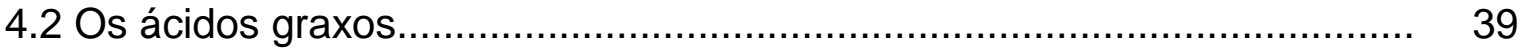

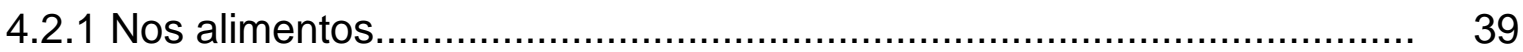

4.2.2 No leite bubalino....................................................................... 46

4.2.2.1 Teor de CLA

4.2.2.1.1 Variação individual................................................................. 46

4.2.2.1.2 Variação no teor de CLA no leite de acordo com o período do ano

4.2.2.1.3 Teor de CLA no leite ao longo do ano....................................... 51

4.2.2.1.4 Ácidos graxos totais analisados através de análise multivariadas.... 56

4.2.2.1.5 Ácidos graxos totais.................................................................. 60

4.3 Atividade da enzima $\Delta^{9}$-dessaturase ................................................... 65

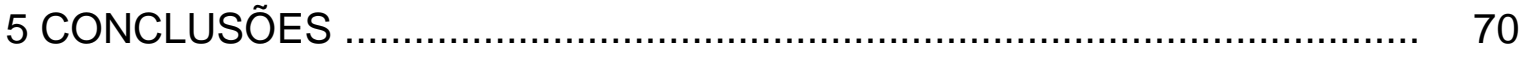

ANEXOS

REFERÊNCIAS BIBLIOGRÁFICAS ........................................................ 73 


\section{LISTA DE FIGURAS}

Página

1 Estrutura de ácidos iso e anteiso..................................................... 15

2 Representação da biohidrogenação ruminal dos ácidos linoléico e linolênico e produção de CLA no tecido mamário............................... 20

3 Variação no teor de CLA no leite de búfalas confinadas..................... 47

4 Variação no teor de CLA no leite de búfalas em

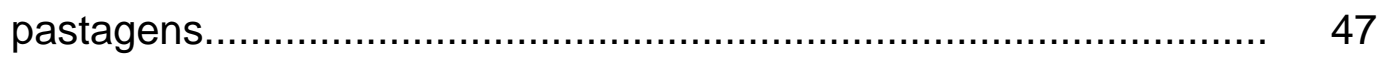

5 Efeito de estação do ano (seca $x$ águas) sobre o teor de CLA no leite de búfalas........................................................................... 51

6 Relação entre os ácidos graxos no leite de búfalas, analisados através de análises multivariadas..................................................... 57

7 Representação da biohidrogenação ruminal dos ácidos linoléico e linolênico e produção de CLA no tecido mamário em dieta com elevado teor de ácido linoléico....................................................... 68 


\section{LISTA DE TABELAS}

Página

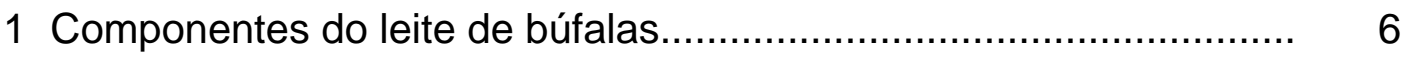

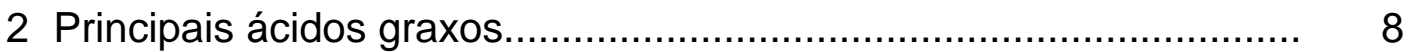

3 Composição dos ácidos graxos de gramíneas de clima temperado

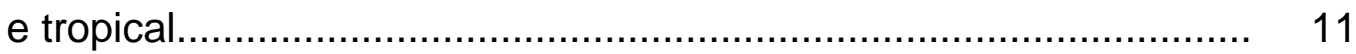

4 Resenha climatológica da região de Itapetininga.............................. 26

5 Características das fazendas estudadas........................................ 28

6 Teores de gordura, proteína e nitrogênio uréico no leite de búfalas ao longo da lactação.................................................................. 35

7 Teores de sólidos totais e lactose no leite de búfalas ao longo da lactação

8 Composição da fração lipídica e ácidos graxos das plantas forrageiras tropicais, com base na matéria seca............................. 41

9 Composição percentual da fração lipídica do resíduo de cervejaria de acordo com o período do ano e por fazenda.............................. 44

10 Composição percentual da fração lipídica de alimentos utilizados em dietas para bubalinos nas fazendas estudadas.............................. $\quad 45$

11 Teor de CLA ( $\left.\mathrm{C}_{18: 2 c 9 t 11}\right)$ na gordura do leite de búfalas ao longo da

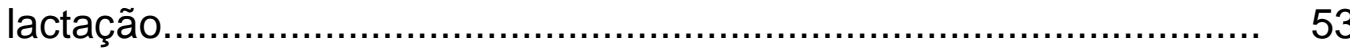

12 Percentual médio de ácidos graxos presentes no leite de búfalas...... 61

13 Aferição indireta da atividade da enzima $\Delta^{9}$-dessaturase na glândula mamária de bubalinos (relações entre os ácidos graxos) 


\title{
LEVANTAMENTO EXPLORATÓRIO DA PRODUÇÃO, COMPOSIÇÃO E PERFIL DE ÁCIDOS GRAXOS DO LEITE DE BÚFALAS EM CINCO FAZENDAS DO ESTADO DE SÃO PAULO
}

\author{
Autor: SÉRGIO AUGUSTO DE ALBUQUERQUE FERNANDES \\ Orientador: Prof. Dr. WILSON ROBERTO SOARES MATTOS
}

\section{RESUMO}

Os objetivos deste experimento foram os de realizar levantamento exploratório da produção, composição e perfil de ácidos graxos do leite de búfalas e dos alimentos utilizados em cinco fazendas da região de Sarapuí e Pilar do Sul, no Estado de São Paulo. Foram coletadas amostras mensais de leite de oito búfalas por fazenda e de alimentos durante os meses de abril a novembro de 2002. Das cinco fazendas, uma explorava sistema de confinamento total e quatro usavam sistemas de produção a pasto com suplementação volumosa no inverno (silagem de gramíneas e cana-de-açúcar) e concentrado (resíduo de cervejaria ou mistura comercial) o ano todo.Três propriedades realizavam duas ordenhas diárias, e as demais apenas uma. Os teores de gordura, proteína e lactose variaram de 5,4 a 8,6\%, 3,7 a 4,9\% e 4,5 a $5,6 \%$, respectivamente, valores normais para bubalinos. Os teores de gordura e de proteína aumentaram ao longo da lactação, enquanto o teor de lactose 
acompanhou a curva de lactação. O teor de nitrogênio uréico no leite variou entre 5,6 e 27,3 mg/dL, com valor médio em todas as fazendas de $15,9 \mathrm{mg} / \mathrm{dL}$, inferior ao observado na literatura para bubalinos. Do total de ácidos graxos na B. decumbens o ácido linoléico variou de $18,2 \%$ no inverno para $19,9 \%$ no verão e o ácido linolênico de $20,8 \%$ no inverno para $31,4 \%$ no verão. A $B$. ruziziensis apresentou teor de ácido linoléico $17,7 \%$ no inverno e $19,4 \%$ no verão, enquanto o ácido linolênico variou de 50,2\% no inverno para 45,6\% no verão. Observou-se grande variação individual no teor de CLA no leite de bubalinos $(0,31-3,42 \%)$. Nos animais a pasto ou com suplementação volumosa de gramíneas frescas a variação foi maior $(0,44$ a 3,31\%) que nos animais confinados (0,31 a 1,74\%). Os teores obtidos de CLA no verão foram em média mais elevados (38,6\%), que no inverno, nos rebanhos em pastejo. A Análise de Componentes Principais confirmou a correlação positiva entre os ácidos graxos de cadeia ímpar e de cadeia ramificada e alta correlação entre os ácidos capróico, caprílico e cáprico. Também indicou correlação negativa entre os ácidos graxos de cadeia longa com os de cadeia curta, média, ímpar e ramificada. O teor dos ácidos graxos hiper-colesterolêmicos (ácidos láurico, mirístico e palmítico) diminuiu à medida que houve elevação do teor de ácidos graxos de cadeia longa no leite. A atividade da enzima $\Delta^{9}$-dessaturase, medida indiretamente (relação produto $x$ substrato), foi maior em animais que receberam resíduo de cervejaria em menor quantidade ao longo do ano. 


\title{
MILK PRODUCTION, COMPOSITION AND FATTY ACIDS PROFILE IN FIVE BUFFALO FARMS IN THE STATE OF SAO PAULO
}

\author{
Author: SÉRGIO AUGUSTO DE ALBUQUERQUE FERNANDES \\ Adviser: Prof. Dr. WILSON ROBERTO SOARES MATTOS
}

\section{SUMMARY}

The objective of this study was to determine milk production, composition and fatty acids profiles in five buffalo farms in the Sarapui and Pilar do Sul counties, in the Southeast region of the State of Sao Paulo. Monthly feed and milk (from eight animals per farm) samples were collected from April to November 2002. In one farm animals were housed in total confinement and were fed a TMR ration; wet brewers grains and a commercial grain mix and summer pasture and a mixture of grass silage plus chopped sugar cane during winter were offered in the remaining farms. Animals were milked twice daily in three farms. Milk fat, protein and lactose contents varied from 5.4 to8.6\%, 3.7 to $4.9 \%$ and 4.5 to $5.6 \%$, respectively. Milk fat and protein contents increased as the lactation progressed. Milk urea nitrogen showed a large variation among farms (5.6 to $27.3 \mathrm{mg} / \mathrm{dL}$ ). The content of linoleic and linolenic acids in $B$. decumbens varied from 18.2 and $20.8 \%$ (winter) to 19.9 and $31.4 \%$ (summer) and in $B$. ruziziensis varied from 17.7 and $50.2 \%$ (winter) to 19.4 and $45.6 \%$ (summer). "Milk CLA content showed a large variation among animals (0.31 to 
3.42\%). Pasture fed or green chopp supplemented animals showed a larger variation (0.44 to $3.31 \%$ ) than TMR fed animals ( 0.31 to $1.74 \%$ ). Milk CLA content was higher (39\%) during summer than in winter, in pasture fed animals. Principle Component Analysis confirmed the positive correlation between odd chain and side chain fatty acids and a high correlation among caproic, caprilic and capric acids. It also showed a negative correlation between long chain fatty acids and short and medium chain and odd and side chain fatty acids. Milk hiper-colesterolemic fatty acids (lauric, miristic and palmitic acids) content decreased as the long chain fatty acids did increased. The indirectly measured Delta 9 dessaturase activity was higher in animals being offered small amounts of wet brewers grains throughout the lactation. 


\section{INTRODUÇÃo}

A bubalinocultura ocupa, em regiões como a Ásia, importante papel como produtora de alimento de alto valor biológico para o homem. Na Europa, especialmente na Itália, destaca-se como importante atividade econômica. No Brasil, a bubalinocultura tem apresentado grande crescimento, causado pela procura dos produtos lácteos. Em São Paulo, tem-se observado, também, este crescimento.

A saúde tem se tornado, à cada dia, fator de preocupação do homem moderno, e indiscutivelmente, tem produzido efeitos positivos sobre sua longevidade. Esta encontra-se estreitamente associada aos bons hábitos alimentares, entre outros fatores. Nos últimos anos tem sido observado aumento no uso de alimentos nutracêuticos (alimentos com propriedades medicinais), como forma de prevenção contra certas doenças.

O leite de bovídeos possui grande importância econômica e social, em todo o mundo, devido, principalmente, às suas características nutritivas. No Brasil, a produção leiteira tem se elevado, com perspectivas de auto-suficiência no corrente ano. Entretanto, há de se observar que o consumo per-capita é muito baixo no Brasil (aproximadamente $135 \mathrm{~kg}$ de leite por habitante por ano). Atualmente, devido às suas características como alimento nutracêutico, após descoberta de que nutrientes contidos na fração lipídica do leite possuem ação preventiva contra doenças cardiovasculares e câncer, entre outras, foi observado grande incremento nas pesquisas que buscam entender a ação destes nutrientes isoladamente. Assim, chegou-se ao ácido linoléico conjugado (CLA, do inglês, conjugated linoleic acid), uma família de isômeros do ácido linoléico, encontrado em muitos alimentos, destacando-se os alimentos de 
origem animal, principalmente, o leite de bovídeos e seus subprodutos, como a maior fonte natural de CLA na dieta humana. Com isso, tem-se buscado, através de experimentos com nutrição animal, estratégias que elevem sua concentração no leite de bovídeos, visto a possibilidade de se alterar o teor de gordura do leite, assim como sua composição, através da manipulação da dieta.

As pesquisas sobre CLA têm sido desenvolvidas, quase que exclusivamente, em regiões de clima temperado e poucas em regiões tropicais, especialmente com búfalos. Assim, a geração de conhecimento científico sobre os ácidos graxos, tanto de forragens como de alimentos concentrados e os possíveis efeitos sobre a composição lipídica do leite, é necessária, no sentido de se determinar as influências do ambiente tropical. Nesse contexto, não parece prudente se adotar conhecimentos gerados em outras espécies (bovinos) e regiões indiscriminadamente. Dessa maneira, o estudo sobre a produção, composição e, em especial, o teor de CLA em leite de búfalos sob condições tropicais irá preencher as lacunas existentes nessa área do conhecimento.

Dessa forma, os objetivos deste experimento foram os de determinar a produção e composição do leite, as concentrações dos ácidos graxos, em especial a concentração de CLA, no leite de búfalas submetidas a diferentes dietas, assim como estabelecer a concentração dos ácidos graxos nos alimentos utilizados por estes em regiões tropicais. 


\section{REVISÃO DE LITERATURA}

Os ruminantes se destacam entre os animais domésticos pela importante função de transformar alimentos não utilizados pelo homem, em nutrientes de alto valor biológico. Diversas são as funções dos ruminantes na economia, destacando-se a produção de pêlos (lã), couro, trabalho, e, sem dúvida, os mais importantes, a carne e o leite.

O leite possui grande valor nutricional para o homem, expresso pelo destaque dado pela Organização Mundial de Saúde, que coloca seu consumo como indicador de saúde pública. Esta organização recomenda o consumo per capita de pelo menos $500 \mathrm{~mL} / \mathrm{leite} / \mathrm{dia}$, para jovens ou idosos, no entanto, este deve ser em torno de $1.000 \mathrm{~mL} /$ dia (Costa, 1999).

\subsection{Composição do leite}

O leite é produto da secreção mamária composto por gordura, proteína, açúcares, minerais e vitaminas, além da água. Possui elevada importância (fluido ou processado) na alimentação humana, sendo considerado produto de alto valor biológico, devido à sua equilibrada composição em nutrientes.

Alguns componentes do leite como as proteínas e ácidos graxos originam-se, em pequena parte do plasma sangüíneo em condição pré-formada e em maior proporção é sintetizada na glândula mamária, a partir de precursores oriundos do plasma sangüíneo. As vitaminas e minerais são obtidos pré-formados do plasma sangüíneo, enquanto a lactose é sintetizada exclusivamente na glândula mamária. 
A gordura do leite de ruminantes é formada, na sua maior parte, por triglicerídeos (97-98\%) que são compostos por três ácidos graxos ligados covalentemente a uma molécula de glicerol por pontes éster, e pequenas quantidades de esteróis, ácidos graxos livres e fosfolipídeos. Os triglicerídeos são sintetizados nas células epiteliais mamárias e os ácidos graxos usados para sua síntese são obtidos pré-formados da dieta ou da mobilização das reservas corporais (ácidos graxos não esterificados - AGNE e lipoproteína de muito baixa densidade - VLDL), essa fonte fornece os ácidos graxos de cadeia longa e cerca de $40 \%$ do ácido palmítico. A partir de acetato e $\beta$-hidroxibutirato, originam-se os ácidos graxos de cadeia média e curta que são sintetizados na própria glândula mamária. Os ácidos graxos de cadeia ímpar e ramificada originam-se da população microbiana do rúmen e também chegam préformados na glândula mamária (Palmquist et al., 1993; Dado et al., 1993; Kennely, 1996; Chilliard et al., 2000).

A proteína total do leite compõe-se de várias proteínas específicas, sendo a mais importante a caseína (com seus diversos tipos: $\alpha, \beta, \gamma$ e $\kappa$ ) que perfaz, aproximadamente, $85 \%$ das proteínas totais do leite. A caseína ( $\alpha, \beta, \gamma$ e к), encontra-se em forma de grânulos insolúveis, denominados micelas; o restante se divide entre lacto-albumina, lacto-globulina e imunoglobulinas. Noventa porcento das proteínas do leite originam-se de aminoácidos livres do sangue, e o restante, das proteínas séricas (Gonzaléz, 2001; Tronco, 2003).

Aproximadamente 94 a 95\% do nitrogênio total do leite é composto por nitrogênio protéico, respondendo pelo restante o nitrogênio não protéico (NNP). Do NNP, 30 a 50\% são compostos por uréia, o restante por creatina, ácido úrico, aminoácidos e amônia. O teor de nitrogênio uréico no leite é influenciado pela ingestão de proteína bruta da dieta, pela fração da proteína degradável no rúmen (PDR) e da proteína não degradável no rúmen (PNDR), além da relação destas com a ingestão de energia. Quando a ingestão de carboidratos fermentescíveis no rúmen é ideal, os microrganismos captam a PDR mais eficientemente, transformando a amônia ruminal em proteína microbiana. A 
percentagem de $\mathrm{N}$ uréico no leite tem sido usada em bovinos leiteiros, como parâmetro, para se avaliar o sincronismo de utilização de nitrogênio e carboidratos no rúmen. A concentração de $\mathrm{N}$ uréico no leite, referenciada como ideal em bovinos, situa-se entre 10 e 16 mg/dL (Roseler et al., 1993; Jonker et al., 1998; Gonzaléz, 2001; Bovera et al. 2001).

Além destes compostos, o leite possui lactose, seu principal açúcar. A lactose é um dissacarídeo composto por D-glicose e D-galactose, unidos através de ligações glicosídicas $\beta$ 1,4. Basicamente é encontrada no leite, embora tenha sido determinada em algumas frutas (Gonzaléz, 2001; Tronco, 2003). A formação de uma molécula de lactose requer duas moléculas de glicose originadas do plasma sangüíneo e através da gliconeogênese no fígado (em ruminantes a glicose é obtida a partir do propionato e de aminoácidos glicogênicos como a alanina, asparagina, metionina, serina, entre outros). Uma dessas moléculas de glicose após alguns eventos na célula (citosol) se transforma em UDP-galactose que é transportada ativamente para o interior do aparelho de Golgi, sendo então liberada para a síntese de lactose, a segunda molécula de glicose é transportada para o interior do aparelho de Golgi pelo transportador de glicose (GLUT 1). No aparelho de Golgi a molécula de galactose e glicose são unidas pela ação da enzima lactose sintetase, formando a molécula de lactose (Vargas, 1996; Hurley, 2004).

Após sintetizada a lactose não sofre hidrólise, assim como não se difunde para o exterior do complexo de Golgi ou da vesícula secretora (invólucro utilizado pela célula para secretar lactose para o lúmen alveolar) e como as membranas celulares são semipermeáveis (apenas a água se move livremente através destas), no processo de síntese de leite a lactose atrai água para o interior das células para balancear a pressão osmótica da vesícula secretora. Em função disso, é o componente do leite que menos varia (Vargas, 1996; Hurley, 2004). 
A composição do leite varia em função da proteína bruta na dieta, a espécie animal, raça e estágio de lactação e momento da ordenha, influenciam (Gonzaléz, 2001; Durr et al, 2001; Bauman \& Griinari, 2003).

$\mathrm{Na}$ Tabela 1, são apresentados os teores médios para os componentes do leite de búfalos obtidos em várias pesquisas. Os resultados obtidos em pesquisas nacionais por Tonhati (1999), Duarte et al. (2001) e Faria et al. (2002), quando comparados com a literatura internacional, como o NRC (1981) e Bovera et al. (2001) são similares.

Tabela 1. Componentes do leite de búfalas

\begin{tabular}{lcccccc}
\hline Fonte & \multicolumn{5}{c}{ Componentes } \\
\cline { 2 - 6 } & Água & Gordura & Proteína & Lactose & N uréico \\
NRC (1981) & 82,0 & 7,5 & 0 & 4,4 & 4,8 & $\mathrm{mg} / \mathrm{dL}$ \\
Campanile et al. (1998) & - & - & - & - & $30,3-37,3$ \\
Tonhati (1999) & - & 6,9 & 3,9 & - & - \\
Duarte et al. (2001) & 82,5 & $5,6-7,8$ & 4,2 & 5,2 & - \\
Mesquita et al. (2001) & $82,2-83,3$ & $6,1-10,4$ & $3,8-4,0$ & $5,4-5,8$ & - \\
Bovera et al. (2001) & - & $6,6-8,4$ & $4,3-4,9$ & - & $28,5-34,3$ \\
Faria et al. (2002) & $81-84,2$ & $5,5-8,3$ & $4,2-4,5$ & - & - \\
\hline
\end{tabular}

Em bubalinos o teor de gordura no leite se mantém sempre acima de 5,5\% (Tabela 1), sendo esta uma característica particular da espécie, independente das condições experimentais, pois no Brasil os teores médios variam entre $5,5 \%$ e 10,4\%, com valores médios mais próximos a 6,0\% (Tonhati, 1999; Duarte et al., 2001; Mesquita et al.; 2001; Faria et al.,2002), similares aos valores observados no exterior (6,6 a 8,4\%) de acordo com NRC (1981) e Bovera et al. (2001). De forma geral, o teor de gordura no leite de búfalos, como em bovinos, tende a crescer com o avançar da lactação.

Para o teor de proteína do leite, ocorre a mesma tendência de variação ao longo da lactação. Duarte et al. (2001), encontraram teor médio de proteína bruta no leite de 4,2\%, com o maior valor no início da lactação enquanto Mesquita et al. (2002) encontraram média de 3,6\% no início da lactação; 3,8\% 
no meio, atingindo 4,0\% no final de lactação, para a raça Murrah. Bovera et al. (2001) encontraram teor médio de proteína bruta no leite de búfalas da raça Mediterrânea, de 4,3\% no início, atingindo no final da lactação 4,9\%.

Para bubalinos, poucas são as referências para a concentração de $\mathrm{N}$ uréico no leite. Campanile et al. (1998) e Bovera et al. (2001), na Itália, em bubalinos submetidos a dietas com $9,0 \%$ e $12,0 \%$ de proteína bruta, encontraram valores médios de $\mathrm{N}$ uréico no leite, variando entre 29,4 e 37,3 $\mathrm{mg} / \mathrm{dL}$.

Ao passo que, a lactose, principal carboidrato no leite, é o componente que menos varia, devido à sua osmolalidade (Sutton, 1989; Vargas, 1996). Duarte et al. (2001), estudando rebanho bubalino no Estado de São Paulo, detectaram percentagem média de lactose de 5,2\%, observando, também, pouca variação ao longo da lactação, similar ao encontrado por Mesquita et al. (2002), cuja concentração média no início da lactação foi de 5,4\%, atingindo o ponto mais alto no meio lactação $(5,8 \%)$, voltando a cair no final $(5,5 \%)$.

\subsection{Natureza dos lipídeos}

Os lipídeos, uma das mais importantes biomoléculas, são substâncias encontradas em tecidos vegetais e animais, insolúveis em água e solúveis em solventes orgânicos, como éter, benzeno e clorofórmio. Atuam no organismo animal como portadores de elétrons, transportadores de substâncias nas reações enzimáticas, compõem as membranas biológicas e servem como reserva energética. Classificam-se de acordo com suas funções biológicas como: de reserva, plásticas, esteróides e outros (McDonald et al., 1999).

$\mathrm{Na}$ Tabela 2, observam-se os ácidos graxos mais comuns, com seus nomes comuns e sistemáticos e suas temperaturas de fusão.

Os triglicerídeos, relacionados à reserva energética em vegetais e animais, são formados por triésteres de glicerol e ácidos graxos, cuja 
composição em ácidos graxos pode variar (Van Soest, 1994; McDonald et al., 1999).

Tabela 2. Principais ácidos graxos

\begin{tabular}{|c|c|c|c|}
\hline \multirow{2}{*}{\multicolumn{4}{|c|}{$\begin{array}{l}\text { Símbolo }^{1} \quad \text { Nome comum } \\
\text { Ácidos Graxos saturados }\end{array}$}} \\
\hline & & & \\
\hline $\mathrm{C}_{4: 0}$ & Butírico & Tetranóico & $-8,0$ \\
\hline$C_{6: 0}$ & Capróico & Hexanóico & $-3,2$ \\
\hline$C_{8: 0}$ & Caprílico & Octanóico & 15,0 \\
\hline$C_{10: 0}$ & Cáprico & Decanóico & 31,0 \\
\hline $\mathrm{C}_{12: 0}$ & Láurico & Dodecanóico & 44,2 \\
\hline $\mathrm{C}_{14: 0}$ & Mirístico & Tetradecanóico & 52,0 \\
\hline$C_{16: 0}$ & Palmítico & Hexadecanóico & 63,1 \\
\hline $\mathrm{C}_{18: 0}$ & Esteárico & Octadecanóico & 69,1 \\
\hline$C_{20: 0}$ & Araquídico & Eicosanóico & 75,4 \\
\hline $\mathrm{C}_{22: 0}$ & Beênico & Docosanóico & 81,0 \\
\hline$C_{24: 0}$ & Lignocérico & Tetradocosanóico & 84,2 \\
\hline \multicolumn{4}{|c|}{ Ácidos graxos insaturados (todas as ligações duplas são cis) } \\
\hline$C_{16: 1}$ & Palmitoléico & 9-hexadecenóico & $-0,5$ \\
\hline $\mathrm{C}_{18: 1}$ cis & Oléico & 9-octadecenóico & 13,2 \\
\hline $\mathrm{C}_{18: 2}$ & Linoléico & 9,12-octadecadienóico & $-9,0$ \\
\hline$C_{18: 3}$ & $\alpha$-linolênico & 9,12,15-octadecatrienóico & $-17,0$ \\
\hline $\mathrm{C}_{18: 3}$ & $\gamma$-linolênico & 6,9,12-octadecatrienóico & $-17,0$ \\
\hline$C_{20: 4}$ & Araquidônico & 5,8,11,14-eicosatetraenóico & $-49,5$ \\
\hline
\end{tabular}

Fonte: Harwood (1980); McDonald et al. (1999); Baer (1996); Lawless et al. (1998); Voet et al. (2002)

Os galactolipídeos são lipídeos compostos, em que dois grupos alcoólicos, do glicerol, estão esterificados com ácidos graxos, e o terceiro unido à galactose. Aproximadamente, $60 \%$ dos lipídeos das gramíneas e leguminosas são galactolipídeos, e são compostos, quase que exclusivamente, por ácido linolênico (95\%), o restante é composto pelo ácido linoléico (Van Soest, 1994; McDonald et al., 1999).

Os fosfolipídeos, também do grupo de lipídeos compostos, compõem-se de uma molécula de glicerol com duas posições esterificados com ácidos graxos, e a terceira com ácido fosfórico. A função principal desse grupo de 
lipídeos é formar parte dos complexos lipoprotéicos das membranas biológicas (Van Soest, 1994; McDonald et al., 1999; Voet et al. 2002).

Os ácidos graxos são ácidos carboxílicos com longas cadeias laterais de hidrocarbonetos. Ocorrem, em geral, esterificados como componentes de vários lipídeos (Voet et al. 2002). O tamanho de sua cadeia carbônica, o número de saturações e sua isomeria (cis ou trans) são parâmetros utilizados na classificação dos ácidos graxos (Byers \& Schelling, 1993).

\subsection{Os lipídeos nos alimentos de ruminantes}

Nos vegetais, os lipídeos podem ser agrupados em dois tipos: estruturais e de reserva. O primeiro grupo compõe as membranas biológicas e as superfícies de proteção (ceras). Os lipídeos de membrana encontrados, principalmente na mitocôndria, retículo endoplasmático e membranas plasmáticas, são compostos principalmente por glicolipídeos (40 a 50\%) e fosfolipídeos. Já os lipídeos de reserva, encontrados nos frutos e sementes, são, predominantemente, na forma de óleos (McDonald et al., 1999)

Os ácidos graxos mais comuns em vegetais são: mirístico $\left(\mathrm{C}_{14: 0}\right)$, palmítico $\left(\mathrm{C}_{16: 0}\right)$, esteárico $\left(\mathrm{C}_{18: 0}\right)$, linoléico $\left(\mathrm{C}_{18: 2}\right)$ e linolênico $\left(\mathrm{C}_{18: 3}\right)$, que juntos totalizam, aproximadamente, $90 \%$ da fração lipídica, enquanto os ácidos graxos, com 20 e 22 átomos de carbono, em geral, encontram-se em baixos teores (Harwood, 1980; Van Soest, 1994).

Em análise de alimentos, os lipídeos compõem, aproximadamente, 43\% do extrato etéreo; o restante é composto por matéria não saponificável, como ceras e clorofila, sem valor nutricional para ruminantes. Em cereais, 65 a 80\% do extrato etéreo, são lipídeos, e em sementes, 90\% (Byers \& Schelling, 1993; Van Soest, 1994).

O tipo de lipídeo, em vegetais, varia de acordo com sua localização na planta. Nas sementes, encontram-se principalmente os triacilgliceróis ou triglicerídeos, associados às reservas energéticas. São os mais encontrados 
nos alimentos concentrados que constituem parte da dieta de ruminantes, já que esses, em geral, são subprodutos de sementes. Nas folhas, os lipídeos mais comuns são os galactolipídeos, constituídos por glicerol, galactose e ácidos graxos insaturados, e os fosfolipídeos, que estão associados às membranas biológicas. Os ácidos graxos polinsaturados, como o linolênico $\left(\mathrm{C}_{18: 3}\right)$ e linoléico $\left(\mathrm{C}_{18: 2}\right)$, compõem a maioria dos ácidos graxos presentes nas forrageiras (Harwood, 1980; Byers \& Chelling, 1993; Van Soest, 1994; Bauman et al., 1999).

Os lipídeos são característicos de folhas metabolicamente ativas. Com o avançar do estádio vegetativo, o número de folhas diminui alterando-se a relação folha/caule, caindo, também, o número de cloroplastos. Dessa forma, o teor de lipídeos, também, decresce e determina queda no teor de ácidos graxos, principalmente os polinsaturados. Dessa maneira, a distribuição, o conteúdo e a proporção dos ácidos graxos nos tecidos das plantas variam com o seu estádio vegetativo (McDonald et al., 1999; Guil-Guerrero et al., 2001; Elgersma et al., 2003). Com essas observações, os autores concluíram que a formação do aparato fotossíntético provoca mudanças na composição lipídica dos vegetais.

A dieta natural, gramíneas e leguminosas, dos herbívoros, possui baixo teor de lipídeos e situa-se entre 1 e 4 \% da matéria seca (Van Soest, 1994). As gramíneas de clima temperado possuem elevadas quantidades de ácido linolênico e linoléico e, em geral, podem totalizar mais de $70 \%$ dos ácidos graxos, enquanto as gramíneas de clima tropical, possuem menores teores de ácido linolênico, em geral, próximo a 50\% dos ácidos graxos (Tabela 3). 
Tabela 3. Composição de ácidos graxos de gramíneas de clima temperado e tropical

\begin{tabular}{|c|c|c|c|c|c|c|}
\hline \multirow[t]{2}{*}{ Espécie } & \multicolumn{5}{|c|}{ Ácidos graxos } & \multirow[t]{2}{*}{ Autor $^{1}$} \\
\hline & $\mathrm{C}_{16: 0}$ & $\mathrm{C}_{18: 0}$ & $\mathrm{C}_{18: 1}$ & $\mathrm{C}_{18: 2}$ & $\mathrm{C}_{18: 3}$ & \\
\hline \multicolumn{7}{|l|}{ Temperadas } \\
\hline L .perenne (fresca) & 14,6 & 1,2 & 1,7 & 10,6 & 68,4 & Elgersma et al. (2003) \\
\hline L .perenne (ensilada) & 16,3 & 1,2 & 1,2 & 11,8 & 64,7 & Elgersma et al. (2003) \\
\hline \multicolumn{7}{|l|}{ L .perenne (fresca) } \\
\hline -Rebrota, 23 dias $^{2}$ & 14,7 & 1,2 & 1,3 & 11,1 & 68,1 & Elgersma et al. (2003) \\
\hline -Rebrota 33 dias & 15,6 & 1,3 & 2,0 & 13,5 & 64,2 & Elgersma et al. (2003) \\
\hline \multicolumn{7}{|l|}{ L .perenne (silagem) } \\
\hline -Rebrota, 23 dias $^{2}$ & 14,7 & 1,0 & 1,1 & 12,0 & 66,1 & Elgersma et al. (2003) \\
\hline -Rebrota 33 dias & 16,6 & 1,3 & 1,7 & 14,9 & 60,4 & Elgersma et al. (2003) \\
\hline \multicolumn{7}{|l|}{ L .perenne } \\
\hline - Rebrota 20 dias & 17,2 & 1,6 & 1,9 & 10,6 & 66,2 & Dewhurst et al. (2001) \\
\hline - Rebrota 38 dias & 19,5 & 2,1 & 1,8 & 10,1 & 62,4 & Dewhurst et al. (2001) \\
\hline \multicolumn{7}{|l|}{ L .multiflorum } \\
\hline - Rebrota 20 dias & 15,0 & 1,3 & 2,0 & 11,2 & 68,4 & Dewhurst et al. (2001) \\
\hline - Rebrota 38 dias & 19,4 & 1,8 & 3,3 & 14,3 & 58,4 & Dewhurst et al. (2001) \\
\hline L .perenne (fresco) & 20,8 & 3,3 & 5,4 & 14,0 & 49,1 & French et al. (2000) \\
\hline L .perenne (silagem) & 24,0 & 2,9 & 6,3 & 14,5 & 46,2 & French et al. (2000) \\
\hline \multicolumn{7}{|l|}{ Tropicais } \\
\hline P. maximum (verão) & 30,3 & 4,1 & 6,5 & 27,9 & 23,4 & O'Kelly \& Reich (1976) \\
\hline P. maximum (inverno) & 29,6 & 5,4 & 9,5 & 32,4 & 15,8 & O'Kelly \& Reich (1976) \\
\hline C. gayana (verão) & 23,4 & 2,4 & 6,2 & 19,9 & 34,9 & O'Kelly \& Reich (1976) \\
\hline C. gayana (inverno) & 30,7 & 3,8 & 9,9 & 23,5 & 19,2 & O'Kelly \& Reich (1976) \\
\hline
\end{tabular}

1 - com adaptações; 2 - média de seis cultivares; P. maximum - Panicum maximum cv. Trichoglume; C. gayana - Chloris gayana

De acordo com os dados observados na Tabela 3, o teor do ácido linolênico é menor e o de ácido linoléico maior em gramíneas de clima tropical do que em gramíneas de clima temperado. A estrutura do dossel de gramíneas de clima temperado proporciona maior relação folha/caule, do que a estrutura do dossel de gramíneas de clima tropical, talvez, por este motivo, as plantas 
forrageiras de clima temperado possuam maior teor de ácido linolênico. Contudo, o maior teor de ácido linolênico em plantas de clima temperado, está associado às adaptações destas plantas às condições climáticas ambientais, especialmente, as baixas temperaturas. A temperatura em que ocorre a fusão do ácido linolênico é de menos $17^{\circ} \mathrm{C}$, com isso a membrana, rica em ácido linolênico, permanece com adequada fluidez, mantendo o metabolismo celular normal (Hopkins, 1995).

A conservação de forrageiras (ensilagem e fenação) produz mudanças na concentração dos ácidos graxos, provavelmente, resultante das oxidações e formação de polímeros, assim como, da atividade dos microrganismos presentes e das enzimas vegetais ativas durante o processo (Van Soest, 1994; Elgersma et al., 2003).

Elgersma et al. (2003) constataram redução significativa no teor do $\mathrm{C}_{18: 3}$ e $\mathrm{C}_{18: 1}$ em gramíneas de clima temperado quando estas foram ensiladas (Tabela 3). Esses autores também observaram queda no teor de $\mathrm{C}_{18: 3}$, de acordo com o intervalo de corte, ao se passar de 23 para 33 dias. Quando esse material coletado aos 23 e 33 dias foi ensilado observou-se queda ainda maior no teor do $\mathrm{C}_{18: 3}$, à medida que o intervalo de corte foi maior (Tabela 3 ).

French et al. (2000) também observaram queda no teor de ácido linolênico em gramíneas de clima temperado ensiladas, em relação à mesma gramínea fresca (Tabela 3), corroborando os resultados obtidos por Elgersma et al. (2003).

Dewhurst et al. (2001) também observaram queda no teor do $C_{18: 3}$ quando o intervalo de corte do $L$ perenne passou de 20 para 38 dias, para $o L$. multiflorum, a diminuição foi mais acentuada para este ácido graxo de acordo com o intervalo de corte (Tabela 3), corroborando as informações de Elgersma et al. (2003).

Estudando gramíneas de clima temperado Dewhurst et al. (2002) não observaram mudanças na fração lipídica quando o intervalo de corte foi menor que 30 dias. Com o corte/pastejo, a planta modifica sua fisiologia, iniciando 
novo período de crescimento, não emitindo inflorescência, que provoca diretamente a diminuição do teor de ácidos graxos nas plantas forrageiras. Esse efeito está relacionado com o avançar do período vegetativo da planta, em que ocorre aumento no teor de fibra, alongamento das hastes, e decréscimo na proporção de folhas, além do aumento no teor de triacilgliceróis nas sementes. Esse conjunto de fatores provoca mudanças do perfil de ácidos graxos nas gramíneas, determinados pelas alterações na estrutura do dossel (Van Soest, 1994; Dewhurst et al., 2001; Guil-Guerrero et al., 2001).

O fator genético (espécie) está intimamente relacionado com a composição da fração lipídica das plantas e com seu perfil, demonstrando potencial de exploração de diferentes espécies (Dewhurst et al. 2001; Dewhurst et al. 2002; Elgersma et al., 2003).

O'Kelly \& Reich (1976), desenvolveram estudo com gramíneas de clima tropical, em Queensland, na Austrália. Nesse estudo, foram analisadas diversas forrageiras tropicais (gramíneas e leguminosas). As forrageiras tropicais apresentam queda na percentagem de extrato etéreo no inverno, em relação ao verão; também foram observadas mudanças no perfil de ácidos graxos, em que ocorreu queda no $\mathrm{C}_{18: 3}$ no inverno, em relação ao verão, enquanto os demais ácidos graxos sofreram elevação (Tabela 3).

De modo geral, o $\mathrm{C}_{18: 3}$ é o ácido graxo mais afetado pelas mudanças na estrutura do dossel. De acordo com os diversos autores, alterações fisiológicas na planta, como aumento do teor de fibra e alongamento da haste, determinam a diminuição da relação folha/caule, ocorrendo, com isso, diminuição no teor do $\mathrm{C}_{18: 3}$, já que é nas folhas que se concentra este ácido (Van Soest, 1994; Hopkins, 1995; Dewhurst et al., 2001; Guil-Guerrero et al., 2001).

Manejo de pastagens que proporcione corte da planta em intervalos menores, impede que a mesma complete seu ciclo reprodutivo, que atua diminuindo o teor de ácidos graxos, principalmente o $\mathrm{C}_{18: 3}$ (Dewhurst, 2002).

O perfil de ácidos graxos em resíduo de cervejaria tem sido pouco explorado cientificamente, portanto há pouca informação na literatura. Dados 
publicados por Van Soest (1994) demonstram haver grande quantidade de ácido linoléico e ácido oléico em grãos destilados. Costa et al. (1994), estudando resíduo úmido de cervejaria em São Paulo, oriundo de mesma cervejaria, porém de partidas diferentes $(n=30)$, observaram coeficiente de variação (CV\%) para a percentagem de extrato etéreo e extrativo não nitrogenado (ENN) de 12,0\% para ambos. Constataram valor máximo de 12,9\%, mínimo de $8,1 \%$ e média de 10,4\% de extrato etéreo. De acordo com Van Soest (1994), o percentual médio de extrato etéreo no resíduo de destilaria é de 10,5\%, similar ao encontrado por Costa et al. (1994).

\subsection{Os lipídeos no leite de bovídeos}

Parte dos ácidos graxos secretados no leite de bovídeos, é obtida como ácidos graxos pré-formados (oriundos da dieta ou mobilizado das reservas corporais) do sangue. Cerca de $40 \%$ do ácido palmítico e os ácidos graxos com 18 ou mais átomos de carbono possuem esta origem. Outra parte dos ácidos graxos presentes no leite de bovídeos, como os de cadeia curta $\left(\mathrm{C}_{4: 0}-\mathrm{C}_{10: 0}\right)$ e média $\left(\mathrm{C}_{12: 0}-\mathrm{C}_{16: 0}\right)$ são sintetizados na própria glândula mamária a partir de acetato e $\beta$-hidroxibutirato (Chilliard et al., 2000; Dado et al., 1993).

Os principais ácidos graxos do leite apresentam cadeia carbônica entre 4 e 20 átomos. Os principais ácidos graxos saturados são o palmítico $\left(\mathrm{C}_{16: 0}\right)$, mirístico $\left(\mathrm{C}_{14: 0}\right)$ e o esteárico $\left(\mathrm{C}_{18: 0}\right)$, destacando-se o primeiro, como o de maior teor. Entre os insaturados destaca-se o ácido oléico $\left(\mathrm{C}_{18: 1}\right)$, principalmente, o cis 9 (Palmquist et al., 1993; Lock \& Garnsworthy, 2003; Kay et al., 2004).

A maior característica do leite é sua grande proporção em ácidos graxos de cadeia curta e média, que está relacionada com o aroma e sabor do leite, assim como, com a sua fluidez (Santos et al., 2001).

Outro agrupamento de ácidos graxos comuns no leite de bovídeos é o de cadeia ímpar e de cadeia ramificada, constituído por ácidos: pentadecanóico, $\mathrm{C}_{15: 0}$; iso metiltetradecanóico, $\mathrm{C}_{15: 0}$ iso; anteíso metiltetradecanóico, $\mathrm{C}_{15: 0}$ 
anteíso; heptadecanóico, $\mathrm{C}_{17: 0}$; iso metilhexadecanóico, $\mathrm{C}_{17: 0}$ iso; anteíso metilhexadecanóico, $\mathrm{C}_{17: 0}$ anteíso; e o heptadecenóico, $\mathrm{C}_{17: 1}$. Os ácidos graxos iso e anteíso (Figura 1) recebem esta classificação de acordo com a posição que o grupo metil se encontra na cadeia carbônica; quando se encontra no último átomo de carbono denomina-se iso e, quando no penúltimo, anteíso (Christie, 1982a).
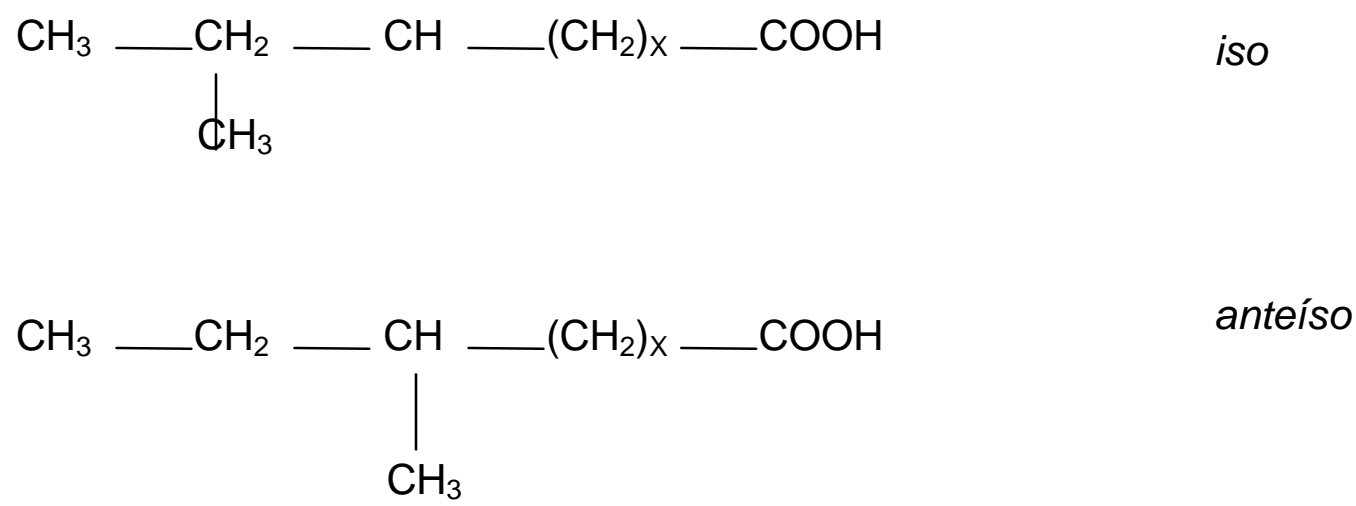

Figura 1 - Estrutura de ácidos iso e anteíso ( Fonte: Christie, 1982a)

Estes ácidos graxos são oriundos, principalmente, dos microrganismos ruminais, que os sintetizam após modificações biossintéticas dos lipídeos dietéticos. Os ácidos graxos de 15 átomos de carbono, e de cadeia linear, predominam entre estes lipídeos (Van Soest, 1994).

No rúmen, o $\mathrm{C}_{17: 1}$ aparece em quantidades ínfimas ou indetectáveis, sendo encontrado no leite (Fievez et al., 2003). Dessa forma, Fievez et al. (2003) sugeriram que este ácido graxo também poderia ser oriundo da atividade da $\Delta^{9}$-dessaturase na glândula mamária.

\section{5 Ácido linoléico conjugado (CLA)}

Ácido linoléico conjugado (CLA) é o termo usado para descrever um ou mais isômeros posicionais e geométricos do ácido linoléico (cis9, cis12, ácido octadecadienóico) contendo duplas ligações conjugadas. Tais ligações, 
geralmente, encontram-se nos átomos de carbono posicionados nas posições 9 e 11 ou 10 e 12, podendo ser de configuração cis ou trans. Produtos provenientes de bovídeos, principalmente os lácteos, são as fontes mais ricas em CLA, sendo o isômero $C_{18: 2 c 9 t 11}$, envolvido em ação anticarcinogênica e o

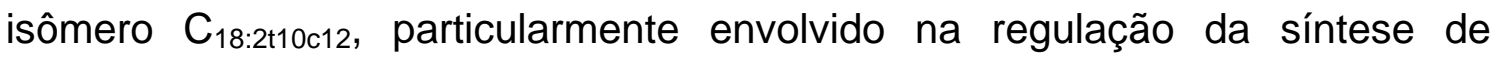
gordura no organismo, sendo os únicos a possuírem atividade biológica reconhecida (Pariza et al., 2000; Yurawecz et al., 2001; Ip, 2001).

\subsubsection{O CLA na saúde humana}

Nos últimos anos, tem ocorrido incremento no interesse pelo CLA devido aos possíveis efeitos benéficos à saúde humana (Christie, 2001). Os efeitos biológicos/fisiológicos dos isômeros de CLA no organismo estão relacionados com a inibição da carcinogênese, redução da aterosclerose, deposição de gordura corporal, aumento da deposição de tecido magro, assim como, na modulação do sistema imune (Bauman et al., 1999; Pariza et al., 2000; Cook, 2001; Pariza, 2001; Mohede et al., 2001; Stanton et al., 2001).

A dieta é a causa de $1 / 3$ das mortes por câncer (Doll, 1992). Modificações nos costumes alimentares podem alterar esta relação. Muitos alimentos possuem efeitos inibitórios sobre algumas doenças humanas. Como exemplo, o consumo de frutas e vegetais tem aumentado, isso foi decorrente a estudos que mostram a redução de câncer em vários órgãos, por meio de agentes anticarcinogênicos existentes nestes alimentos.

Ultimamente, além de frutas e vegetais, os produtos lácteos, ricos em um dos isômeros de CLA ( $\left.\mathrm{C}_{18: 2 c 9, t 11}\right)$ têm sido estudados, como outra alternativa utilizada na prevenção do câncer. Neste texto, a ênfase maior será sobre o isômero de CLA C 18:2c9,t11.

O CLA é reconhecido por sua capacidade anticarcinogênica, confirmados em várias pesquisas em que foram utilizados animais in vivo e em cultura de tecido humano (Ip et al., 1997; Cunninghan et al., 1997; Cesano et al., 1998). Ip 
et al. (1999) observaram que a adição, aproximadamente, 1\% de CLA na dieta, foi suficiente para produzir significativa redução de tumores mamários em ratos tratados com agente carcinogênico e determinaram que o isômero $C_{18: 2 c 9 t 11}$ estava associado ao menor crescimento do epitélio mamário.

Além do câncer de mama, estudos comprovaram a eficiência do CLA em inibir o crescimento de tumores em outros tecidos, como pele e estômago; inibição da proliferação de células de melanoma maligno e câncer de colo-retal e mama (Ha et al., 1990; Cesano et al., 1998).

O mecanismo pelo qual o CLA influencia a carcinogênese, embora muito estudado, não está totalmente elucidado, podendo variar de acordo com o local do câncer, a idade do animal, a duração da exposição à substância carcinogênica e ao estágio da carcinogênese. Vários estudos sugerem relações com a inibição da síntese de proteína e nucleotídeos, redução da atividade proliferativa, entre outros (Ha et al., 1990; Ip et al., 1991; Zu \& Schut, 1992; Liew et al., 1995: Schonberg \& Krokan, 1995).

Lawless et al. (1998) estimaram que o consumo de CLA necessário para a prevenção do câncer, é de aproximadamente $3 \mathrm{~g} /$ dia. Diante deste consumo mínimo, e, assumindo-se que o leite bovino possua entre 3 e $9 \mathrm{mg}$ de CLA/g de

gordura e 3,2\% de gordura (Riel, 1963; Bauman \& Kelly, 1997), estima-se que a ingestão mínima de leite, para atender ao consumo de 3g/dia de CLA, deva ser de $10 \mathrm{~kg} / \mathrm{dia}$.

\subsubsection{O CLA em bovídeos}

A produção de CLA, no leite de bovídeos envolve alguns processos metabólicos, que passam a ser discutidos a partir desta seção. 


\subsubsection{Síntese de CLA no organismo animal}

A produção de CLA, encontrado no leite e tecido de bovídeos, ocorre em duas etapas: i) a biohidrogenação ruminal dos ácidos linoléico e linolênico; e, ii) endogenamente a partir do ácido vacênico $\left(\mathrm{C}_{18: 1111}\right)$, intermediário na biohidrogenação ruminal dos ácidos graxos polinsaturados linoléico e linolênico (Bauman et al. 1999).

\subsection{Biohidrogenação ruminal}

A síntese de CLA no rúmen ocorre pela hidrólise das ligações ésteres dos lipídeos dietéticos, catalisadas pelas lipases microbianas, seguida da biohidrogenação dos ácidos graxos insaturados.

A hidrólise é pré-requisito para que ocorra a biohidrogenação dos ácidos graxos insaturados pelas bactérias ruminais (Bauman et al., 1999; Bessa et al. 2000).

Até pouco tempo atrás, apenas as bactérias Butyrivibrio fibrisolvens eram conhecidas por serem capazes de realizar a biohidrogenação através de suas enzimas linoleato de isomerase e CLA redutase. No entanto, outras bactérias ruminais também participam do processo, ou seja, a biohidrogenação ruminal não é realizada por uma única bactéria, ou em único passo, mas por um grupo delas e seqüencialmente (Kelly et al., 1998; Bauman et al., 1999; Stanton et al., 2001). Este fato talvez explique a formação de diferentes isômeros de CLA, quando do uso de diferentes dietas.

A biohidrogenação ruminal envolve alguns passos bioquímicos e agrupamentos de bactérias ruminais. Primeiramente, as bactérias classificamse em dois grupos: A e B, com ações específicas. As bactérias do grupo A, hidrogenam o ácido linoléico e o ácido linolênico, tendo como produto final o ácido vacênico, enquanto as do grupo $B$ utilizam o ácido vacênico como substrato, tendo como produto final, o $\mathrm{C}_{18: 0}$, ácido esteárico (Bauman et al., 
1999; Lock \& Garnsworthy, 2003). A concentração do ácido vacênico no rúmen é afetada por vários fatores, tais como a concentração de ácidos graxos polinsaturados, pH ruminal e o uso de ionóforos (Bessa et al., 2000). Ainda, segundo esses autores, algumas bactérias possuem mecanismos de isomerização (cis e trans) na membrana celular, que possibilitam a redução de sua fluidez como defesa de agentes tóxicos ou estressantes. Dessa forma, os ácidos graxos trans podem ter papel de proteção da bactéria contra estes agentes estressantes. Portanto, o acúmulo de ácido vacênico no rúmen-retículo pode ser a resposta dada pelos microrganismos às mudanças nas condições ruminais, causadas pelo baixo $\mathrm{pH}$, uso de ionóforos ou alta concentração de ácidos graxos.

A isomerização inicial da dupla ligação cis 12 dos ácidos graxos, que contém dupla ligação nas posições cis 9 e cis 12, é o ponto de partida da biohidrogenação. O ácido linoléico é isomerizado pela enzima linoleato isomerase, resultando na formação do $\mathrm{C}_{18: 2 c 9 t 11}$ (CLA), que pode ser absorvido diretamente ou biohidrogenado (Figura 2). Esta redução (hidrogenação) ocorre rapidamente, transformando-o em ácido vacênico enquanto a hidrogenação do ácido vacênico ocorre mais lentamente, fazendo com que sua concentração ruminal aumente, tornando-o mais disponível para absorção no trato gastrointestinal (Kelly et al., 1998; Bauman et al., 1999). Após a absorção, o ácido vacênico é transportado, via corrente sangüínea, para a glândula mamária, onde é convertido em CLA, através da enzima $\Delta^{9}$-dessaturase (Kelly et al., 1998; Pariza et al., 2000).

Segundo Sutton (1989), a concentração de gordura do leite de bovídeos é o componente mais sensível a alterações por manipulação da dieta. O fornecimento de dietas com alto teor de concentrados, forragens finamente picadas, suplementação da dieta com lipídeos insaturados e adição de ionóforos são manipulações dietéticas que têm resultado na depressão do teor de gordura do leite (Sutton, 1989; Van Soest, 1994). 

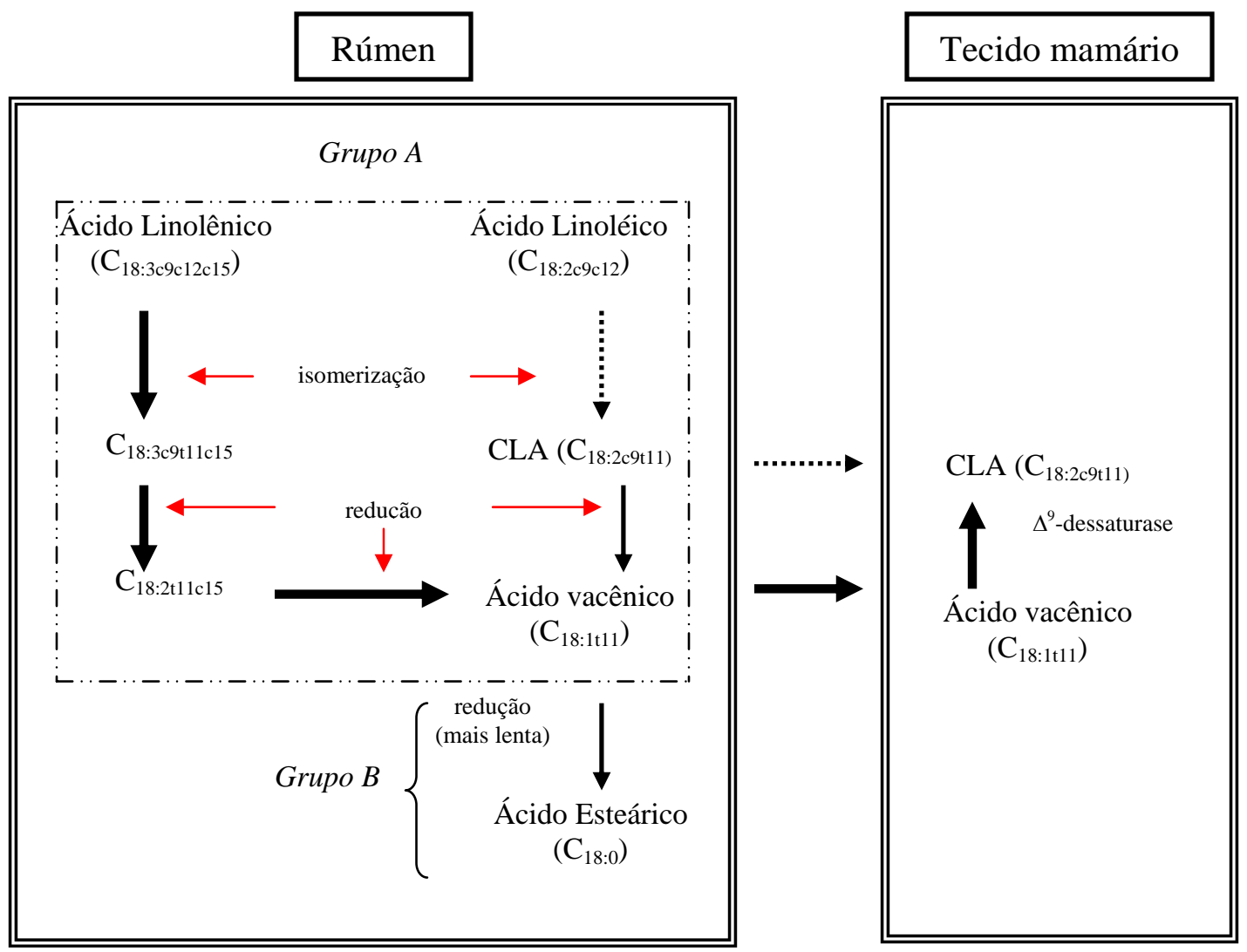

Figura 2 - Representação da biohidrogenação ruminal dos ácidos linoléico e linolênico e produção de CLA no tecido mamário (Fonte: Bauman, 2002)

Outro isômero de CLA com reconhecida atividade biológica é o $\mathrm{C}_{18: 2 t 10 c 12 \text {, }}$ que tem sido relacionado à depressão da gordura do leite (Loor e Herbein, 1998; Chouinard et al., 1999). Três teorias, que buscam explicar a depressão da gordura do leite, com suporte científico, têm predominado, e se baseiam em mudanças provocadas pela dieta. De acordo com Bauman \& Griinari (2003), a primeira teoria propôs alterações nas fermentações ruminais, que alteram a proporção molar dos ácidos graxos voláteis no rúmen, como conseqüência diminui a percentagem de acetato e butirato, precursores de ácidos graxos via síntese de novo, provocando, assim, queda na produção de gordura do leite (Chilliard et al. 2000). 
Outra teoria denominada insulino-glicogênica, proposta inicialmente por McClymont \& Vallance (1962), que atribuiu à insulina a razão pela depressão na gordura do leite. Segundo esta teoria, o aumento da produção de ácido propiônico, causado por dietas com alto teor de grãos e baixa fibra, promoveria elevação da taxa de glicose no sangue, resultando em maior secreção de insulina pelo pâncreas, determinando, assim, aumento da lipogênese no tecido adiposo (Bauman, 2000), causando diminuição no aporte de precursores para a síntese de lipídeos na glândula mamária. Bauman \& Griinari (2003), baseados em resultados de pesquisas, em que não foram observadas respostas que dessem suporte a esta teoria, afirmam que a insulina contribui minimamente para o decréscimo do teor de gordura do leite.

Em 1998, Griinari e colaboradores propuseram a terceira e atual teoria, após observarem que a depressão na gordura do leite estava associada especificamente com o aumento do $\mathrm{C}_{18: 1110}$, formado após a redução do

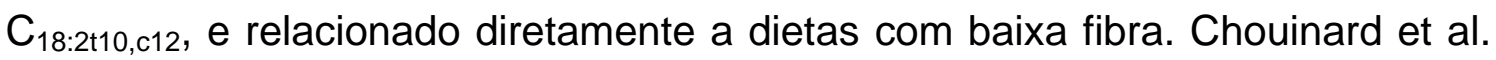
(1999), trabalhando com vacas holandesas com infusão de CLA no abomaso, não observaram aumento na ingestão de matéria seca, porém, detectaram redução significativa na produção e porcentagem de gordura no leite com diminuição nos ácidos graxos de cadeia curta e média $\left(\mathrm{C}_{4: 0}-\mathrm{C}_{14: 0}\right)$ e incremento nos de cadeia longa ( $\left.C_{18: 0}\right)$. Baumgard et al. (2001) infundiram CLA $C_{18: 2110 c 12 \text {, }}$ em diferentes doses, no abomaso de vacas holandesas. Constataram que todas as dosagens reduziram, significativamente, a produção e porcentagem da gordura do leite. A maior redução foi observada na dosagem de $14 \mathrm{~g} / \mathrm{dia}$ (50\%) e de $25 \%$ de redução para a dosagem de $3,5 \mathrm{~g} / \mathrm{dia}$. Os autores observaram também que, durante o período de infusão, a correlação entre a porcentagem

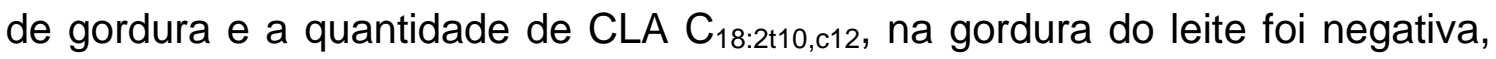
indicando que este isômero está relacionado à depressão da gordura do leite.

De acordo com Bauman \& Griinari (2003) alguns fatores devem estar presentes na dieta para que haja depressão na gordura do leite. Dentre eles, o fundamental é a presença de ácidos graxos polinsaturados e baixa fibra. Estes 
autores afirmam que óleos vegetais não provocam depressão na gordura do leite, se a fibra for suficiente para manter o rúmen funcionando normalmente; contrariamente, o óleo de origem marinha (peixe e algas), mesmo em dietas em que a fibra efetiva é suficiente para manter a atividade ruminal normal, provoca a depressão da gordura do leite.

De acordo com Bauman (2001), os mecanismos específicos de ação deste isômero não são bem definidos, no entanto, recentes descobertas levam a crer que o CLA C $\mathrm{C}_{\text {18:2t10c12 }}$ provoque diminuição de enzimas-chave (RNA mensageiro) associadas à síntese de novo na glândula mamária.

\subsection{Biossíntese em tecidos animais}

Resultados recentes de pesquisa, mostram que a produção endógena de CLA, em ruminantes, ocorre, predominantemente, na glândula mamária, onde a atividade da enzima $\Delta^{9}$-dessaturase é maior em relação a outros tecidos como os adipócitos e o fígado (Bauman et al., 1999).

Após a biohidrogenação ruminal, o ácido vacênico é absorvido e em seguida, chega à glândula mamária, via corrente sanguínea, sendo transformado em CLA ( $\left.\mathrm{C}_{18: 2 c 9 t 11}\right)$.

Baseados na estreita relação entre o ácido vacênico e o CLA na gordura do leite, assim como, no fluído ruminal, Bauman et al. (1999) elaboraram a hipótese da produção endógena do CLA, originado da dessaturação do ácido vacênico $\left(\mathrm{C}_{18: 1111}\right)$, pela $\Delta^{9}$-dessaturase, enzima capaz de introduzir uma dupla ligação cis entre os átomos de carbono 9 e 10. De acordo com vários experimentos esses autores concluíram que a maior fonte de CLA é endógena, representando, aproximadamente $85 \%$ da síntese de CLA. Na realidade, existe

um complexo multienzimático denominado sistema dessaturase, que inclui a $\mathrm{NADH}$-citocromo $b_{5}$ redutase, citocromo $b_{5}$, acilCoA-sintetase e a enzima terminal $\Delta^{9}$-dessaturase (Bauman et al., 1999; Griinari \& Bauman, 1999; Griinari et al., 2000). 
Em situações em que ocorre ingestão de alimentos com elevados teores de ácido linoléico, a contribuição do sistema dessaturase na produção de CLA pode ser diminuída. Tal fato ocorre pelo excesso de $\mathrm{C}_{18: 2 c 9 t 11}$, disponível no rúmen e que chega à glândula mamária como CLA pré-formado. Dessa forma, a origem do pool de CLA presente no leite é dividido entre as fontes endógenas $\left(\Delta^{9}\right.$-dessaturase) e ruminal (Kay et al., 2004). Estes autores sugerem que a atividade da $\Delta^{9}$-dessaturase torna-se mais importante em animais a pasto, já que as pastagens possuem teores mais elevados de ácido linolênico $\left(\mathrm{C}_{18: 3}\right)$, que no processo de biohidrogenação ruminal não produz o isômero $C_{\text {18:2c9t11 }}$ (Figura 2), determinando elevação no teor ruminal e conseqüente absorção do $\mathrm{C}_{18: 1111}$, que será utilizado pela $\Delta^{9}$-dessaturase, como precursor do CLA na glândula mamária.

Embora a concentração do $\mathrm{C}_{14: 1}$ na digesta de ruminantes seja ínfima, ou traço, no leite é encontrado em maior percentual. De acordo com Fievez et al. (2003), ocorre no organismo animal a conversão do ácido mirístico ( $\left.C_{14: 0}\right)$ em miristoléico $\left(C_{14: 1}\right)$ pela enzima $\Delta^{9}$-dessaturase. Dessa forma, a relação entre os ácidos miristoléico e mirístico tem sido utilizada como forma de aferição indireta da atividade da $\Delta^{9}$-dessaturase na glândula mamária (Fievez et al. 2003).

\subsection{Fatores dietéticos ligados à produção de CLA}

Vários fatores afetam a concentração de CLA na gordura do leite, podendo ser agrupados em fatores ambientais, como estação do ano; dietéticos, relacionados com a forma em que é ofertado o volumoso (fresco, ensilado ou fenado), o uso de gordura e óleos e a relação forragem/concentrado. Contudo, a influência da estação do ano pode ocasionar efeito indireto, já que esta exerce influências sobre as forragens. Os teores de CLA, determinados em gramíneas na primavera/verão, foram superiores aos teores encontrados no outono/inverno, época em que ocorre diminuição da oferta de pasto (Prandini et al., 2001; Nilsson et al., 2001). 
Dhiman et al. (1999) relataram que vacas que permanecem em pastejo podem apresentar concentrações de CLA de até $22,7 \mathrm{mg} / \mathrm{g}$ de gordura, podendo apresentar aumento de até 500\% no teor de CLA na gordura do leite, quando comparados aos animais alimentados com 50\% de forragem conservada e $50 \%$ de grãos. Valores de CLA no leite de vacas na Austrália e Nova Zelândia, por possuírem acesso mais freqüente a pastagens novas e ricas em ácidos graxos polinsaturados, são duas ou três vezes maiores que os observados nos Estados Unidos (Parodi, 1996).

De acordo com Lock \& Garnsworthy (2003) é possível que animais que receberam gramíneas frescas, possuam população bacteriana ruminal diferente, com prevalência das bactérias do grupo $A$, como a $B$. fibrisolvens. Estes autores afirmam que, de acordo com resultados de pesquisas, 25\% das bactérias isoladas em dietas que tinham alta participação de volumosos eram principalmente $B$. fibrisolvens e em apenas $2,3 \%$ quando o volumoso tinha baixa participação na dieta. Lembrando que, de acordo com Yokoyama \& Johnson (1993) a B. fibrisolvens pertence aos grupos celulolíticos, hemicelulolíticos e pectinolíticos.

A conservação das gramíneas (ensilagem e fenação) também afeta a produção de CLA. As alterações provocadas pela ensilagem provoca diminuição, principalmente, dos carboidratos, causado pela respiração celular, além, também, da proteólise que pode diminuir o teor de proteína em até $50 \%$ (McDonald et al., 1999). A ensilagem provoca mudanças nos ácidos graxos, que são hidrolisados e hidrogenados. Dessa forma, os teores da maioria dos ácidos graxos, especialmente o $\mathrm{C}_{18: 1}$ e $\circ \mathrm{C}_{18: 3}$ apresentam diminuição com 0 processo de ensilagem. A fenação provoca lenta oxidação e polimerização de óleos polinsaturados, formando resinas, que são indigestíveis, determinando diminuição nos ácidos graxos (Van Soest, 1994; Dhimann et al., 1996; Kelly et al., 1998; Elgersma et al., 2003). Estes fatores, de acordo com French et al. (2000) irão influenciar o ambiente ruminal, provocando queda na produção de CLA. 
Outro fator relacionado com a dieta é seu conteúdo em lipídeos. De forma geral, a inclusão de óleos ricos em ácidos graxos polinsaturados disponibiliza mais substrato para a biohidrogenação ruminal, elevando, assim, os teores de CLA no leite (Griinari et al., 1996; Kelly et al., 1997; Griinari et al., 1998; OKine et al., 2001);

A associação de forragem/concentrado irá interferir no ambiente ruminal. Dietas em que o teor de fibra é baixo, o pH ruminal tende a cair, afetando negativamente determinadas populações microbianas, principalmente, as celulolíticas, relacionadas com a biohidrogenação ruminal dos ácidos graxos polinsaturados (Van Soest, 1994; Griinari et al., 1996 e 1998).

\subsection{Produção de CLA no leite de búfalas}

O teor de CLA em leite de búfalas é pouco conhecido ou pouco publicado. Aneja \& Murthi (1990), estudando, na Índia, o efeito do processamento do leite bubalino e bovino encontraram teor médio de CLA no leite de búfalas em $0,5 \%$, enquanto a média do leite bovino foi de $0,6 \%$ da gordura. Na Itália, Fedele et al. (2001), estudando a influência do sistema de produção (orgânico $\mathrm{x}$ tradicional) sobre o teor de CLA no leite de búfalas, encontraram valores médios de $0,39 \%$ e $0,63 \%$ na gordura para o sistema tradicional e orgânico, respectivamente. Da mesma forma que em bovinos, o teor de CLA no leite de búfalas apresentou alta correlação com os teores de $\mathrm{C}_{18: 1111}\left(\mathrm{r}^{2}=0,89\right)$ e negativamente com o ácido linoléico, o que é esperado, pois mais de $75 \%$ do ácido linoléico, precursor do $\mathrm{C}_{18: 1111}$, pode ser biohidrogenado no rúmen (Mattos \& Palmquist, 1977), enquanto o $C_{18: 1111}$ é o precursor do CLA, na glândula mamária. Com isso, concluíram que o sistema orgânico, cuja dieta é pasto, favoreceu a microbiota ruminal, elevando os teores de CLA no leite.

Os bubalinos parecem sofrer as mesmas influências dietéticas que os bovinos, produzindo, sob mesma dieta, perfil de ácidos graxos similar ao encontrado em bovinos. 


\section{MATERIAL E MÉTODOS}

\subsection{O local do experimento}

Este experimento foi conduzido em cinco fazendas localizadas nos municípios de Pilar do Sul e Sarapuí, na região de Itapetininga, no Sul do Estado de São Paulo.

Na Tabela 4 está apresentada a resenha climatológica da região, no período em que foram colhidas as amostras.

\subsection{A amostragem}

A colheita das amostras de leite e da dieta utilizada em cada fazenda foi mensal, durante o período de abril a novembro do ano de 2002.

Tabela 4. Resenha climatológica da região de Itapetininga

\begin{tabular}{|c|c|c|c|c|c|}
\hline \multirow{2}{*}{ Período (mês) } & \multicolumn{3}{|c|}{ Temperatura mensal } & \multirow{2}{*}{ Precipitação } & \multirow{2}{*}{$\mathrm{DCCH}$} \\
\hline & Máxima & Mínima & Média & & \\
\hline Abril & 27,5 & 19,2 & 23,3 & 21 & 1 \\
\hline Maio & 24,0 & 16,5 & 20,3 & 122 & 9 \\
\hline Junho & 23,4 & 15,0 & 19,2 & 1 & 1 \\
\hline Julho & 21,3 & 11,4 & 16,3 & 29 & 2 \\
\hline Agosto & 25,7 & 15,5 & 20,6 & 63 & 5 \\
\hline Setembro & 23,9 & 13,9 & 18,9 & 118 & 7 \\
\hline Outubro & 30,7 & 19,4 & 25 & 84 & 6 \\
\hline Novembro & 28,0 & 18,8 & 23,4 & 236 & 13 \\
\hline Dezembro & 30,5 & 20,2 & 25,3 & 148 & 11 \\
\hline
\end{tabular}

$\mathrm{DCCH}$, dias com chuva

Fonte: IAC (2004) 
Foi colhida uma amostra mensal de leite de 8 búfalas multíparas por fazenda, em 5 fazendas na região de Sarapuí e Pilar do Sul (SP). Esta amostra foi subdividida e duas subamostras: uma subamostra foi utilizada para determinação do teor de gordura, proteína, lactose e $\mathrm{N}$ uréico no leite. Esta subamostra foi acondicionada em frasco contendo bromopol para conservação; a segunda subamostra serviu para determinação dos teores dos ácidos graxos presentes na gordura do leite, que, após a colheita, foi resfriada em caixa térmica com gelo ou em geladeira, até ser congelada, em intervalo máximo de uma hora, e em seguida estocada a menos $20^{\circ} \mathrm{C}$.

Nas fazendas que realizavam duas ordenhas diárias, as amostras de leite foram colhidas proporcionalmente com a produção de cada animal em cada ordenha. Em duas fazendas a colheita era realizada através de medidores de leite automáticos; nas demais, após a ordenha de cada búfala, o leite era pesado e homogeneizado para a retirada da amostra.

A colheita das amostras dos alimentos foi efetuada no mesmo período de colheita do leite. Adotou-se como critério a amostragem dos alimentos (concentrado e volumoso) que estivessem em uso por, pelo menos, 15 dias antes da data de colheita. Na Tabela 5 pode-se observar os alimentos amostrados. Estas amostras foram resfriadas ou congelados até a chegada ao laboratório, para então serem congeladas a menos $20^{\circ} \mathrm{C}$ até o momento da análise.

A amostragem das pastagens foi realizada através de pastejo simulado, de forma que cada amostra contivesse aproximadamente $1,0 \mathrm{~kg}$ de matéria original.

\subsection{Manejo das fazendas}

Todas as búfalas eram da raça Murrah (Bubalus bubalis L.) ou mestiças, com predominância genética da Murrah, todas multíparas. Na Tabela 5 estão apresentadas as características dos rebanhos avaliados. 
Tabela 5. Características das fazendas estudadas

\begin{tabular}{|c|c|c|c|c|c|}
\hline Item & Faz. 1 & Faz. 2 & Faz. 3 & Faz. 4 & Faz. 5 \\
\hline $\begin{array}{l}\text { Exploração } \\
\text { Dieta }(\mathrm{kg})^{1}\end{array}$ & Confinada & Confinada & Pasto & Pasto & Pasto \\
\hline Volumosa & $S M-35$ & SM; CE; CA - 25 & $\mathrm{BD} ; \mathrm{CA}^{2}-30$ & $\mathrm{BD} ; \mathrm{SM}-30$ & $\mathrm{BR} ; \mathrm{SG}^{4}$ \\
\hline $\begin{array}{l}\text { Concentrada } \\
\text { Lactação }\end{array}$ & $R C-20$ & $R C-30,0$ & $\mathrm{RC}-30$ & $R C^{3}-25,0$ & Fórmula $^{5}$ \\
\hline Início ${ }^{6}$ (dias) & 30 & 54 & 56 & 91 & 31 \\
\hline Duração (dias) & 240 & 235 & 232 & 235 & 275 \\
\hline $\begin{array}{l}\text { Produção }^{7}(\mathrm{~kg}) \\
\text { Ordenha }\end{array}$ & 1.930 & 2.402 & 1.513 & 1.423 & 2.955 \\
\hline Número & 2 & 2 & 1 & 1 & 2 \\
\hline Tipo & Manual & Mecânica & Manual & Manual & Mecânica \\
\hline
\end{tabular}

1 - consumo estimado; 2 - suplementação no período seco; 3 - ofertado em abril, outubro e novembro; 4 - suplementação no período seco (silagem de BR); 5 - 2 kg de caroço de algodão, $2 \mathrm{~kg}$ de polpa cítrica, $10 \mathrm{~kg}$ de resíduo de cervejaria e $50 \mathrm{~g}$ de uréia; 6 - período de lactação médio em que se encontravam as búfalas; 7 - produção média de leite na lactação. SM silagem de milho; RC - resíduo de cervejaria; CE - capim-elefante; CA - cana-de-açúcar; BD Brachiaria decumbens; BR - Brachiaria ruziziensis

Em todas as fazendas, a dieta e a suplementação mineral era ofertada em grupo, o que impossibilitou a quantificação exata da ingestão de matéria seca por animal.

\subsection{Procedimentos laboratoriais e parâmetros avaliados}

O teor de matéria seca dos alimentos foi determinado por meio de secagem em estufa a $55^{\circ} \mathrm{C}$, com circulação de ar. $\mathrm{O}$ extrato etéreo foi determinado de acordo com a IUPAC (1979).

Para a extração e metilação da gordura dos alimentos, foi adaptada a metodologia de Rodriguez-Ruiz et al. (1998) com algumas adaptações, para extração e metilação da gordura dos alimentos. O procedimento utilizado consistiu em se pesar 2 gramas da amostra, colocá-las em tubo de ensaio, adicionar $2 \mathrm{~mL}$ de solução de hexano/cloreto de acetila (20:1 v/v) e aquecer por dez minutos, a $90^{\circ} \mathrm{C}$. Em seguida resfriou-se o tubo de ensaio com o material em temperatura ambiente, após retirou-se a camada sobrenadante e colocouse em um segundo tubo de ensaio para que fosse adicionado carvão ativado e 
sílica gel (adaptações), para extração de ceras e pigmentos que podem interferir na cromatografia. As frações obtidas foram analisadas por meio da cromatografia gasosa.

Para a extração da gordura do leite com fins na análise do perfil de ácidos graxos foi descongelada a amostra, centrifugada (centrífuga refrigerada, sob rotação de $9.000 \mathrm{~g}$, a $8^{\circ} \mathrm{C}$, por 30 minutos), para se concentrar a gordura, após, pesou-se $40 \mathrm{mg}$ de gordura, e adicionou-se solução de hexanoisopropanol, de acordo com metodologia descrita por Hara \& Radim (1978). Para a metilação dos ácidos graxos, seguiu-se a metodologia descrita por Christie (1982b), e adaptada por Chouinard et al. (1999) empregando-se solução básica de metóxido de sódio. Este procedimento tem sido utilizado preferencialmente, devido a possíveis isomerizações do CLA de configuração cis-trans para configurações do tipo trans-trans.

A quantificação dos ácidos graxos do leite e dos alimentos foi realizada através de cromatografia gasosa em equipamento Trace GC 3 , aparelhado com detector de chama (FID), coluna capilar SUPELCO 2-4056 SP ${ }^{\mathrm{TM}}-2560$, DE $100 \mathrm{~m} \times 0.25 \mathrm{~mm}$ de diâmetro, e espessura do filme $0,2 \mu \mathrm{m}$, e como gás de arraste utilizou-se o hidrogênio, com fluxo de $40 \mathrm{~mL} /$ minuto. A temperatura inicial da rampa foi $70^{\circ} \mathrm{C}$ por 4 minutos, em seguida a temperatura foi elevada a $13^{\circ} \mathrm{C}$ /minuto até atingir $175^{\circ} \mathrm{C}$, permanecendo por 27 minutos nesta temperatura $\left(1^{\mathrm{a}}\right.$ rampa), depois elevou-se a $4^{\circ} \mathrm{C} / \mathrm{min}$ até atingir $215^{\circ} \mathrm{C}$, permanecendo por 11 minutos nesta temperatura ( $2^{\mathrm{a}}$ rampa), a $3^{\mathrm{a}}$ rampa foi alcançada aumentando-se a temperatura a $4^{\circ} \mathrm{C} / \mathrm{min}$ até atingir $240^{\circ} \mathrm{C}$, permanecendo por 4 minutos, sendo a temperatura máxima $250^{\circ} \mathrm{C}$. O tempo de corrida de cada amostra foi de 70 minutos, com injeção de $1 \mu \mathrm{L} / \mathrm{amostra}$.

Após a obtenção do perfil de ácidos graxos por cromatografia gasosa, que expressa o teor de ácidos graxos, em percentagem, utilizou-se o padrão CRM-164 (Commission of the European Communities, Community Bureau of Reference, Brussels, Belgium), que possui valores certificados para 11 ácidos 
graxos, que estabelecer os valores de correção para cada ácido graxo encontrado.

Foi realizado o controle leiteiro nos rebanhos, porém no início das colheitas a lactação já havia iniciado em todas as fazendas, como pode-se observar na Tabela 5. Alguns animais encontravam-se em estágios de lactação mais avançados que outros. Foi determinada a composição química do leite (gordura, proteína, lactose e $\mathrm{N}$ uréico), além da contagem de células somáticas e perfil de ácidos graxos do leite, incluindo isômeros de posição e estereoisômeros. A contagem de células somáticas (CCS) foi realizada por citometria de fluxo, utilizando-se o aparelho Somacount 300; a $N$ uréico foi determinada por meio enzimático, em equipamento ChenSpec 150, o qual se baseia em duas etapas: aquecimento até $40^{\circ} \mathrm{C}$, adicionando-se a enzima urease, para que ocorra liberação de amônia e dióxido de carbono, em seguida adiciona-se corante, que corresponde à amônia liberada, sendo então feita a leitura por espectrofotometria. A gordura, proteína e lactose foram feitas mediante leitura de absorção de luz infravermelha, utilizando-se o equipamento Bentley 2000 (Durr et al., 2001).

\subsection{Análise estatística}

O delineamento experimental utilizado foi o inteiramente casualizado com 8 repetições (búfalas) por fazenda (fator) em esquema de parcela subdividida com medidas repetidas no tempo. Nos últimos meses o número de repetições diminuiu devido ao período de lactação estar chegando ao fim, pois na última colheita, em novembro, na Fazenda 1, haviam dois animais em lactação; na Fazenda 2, três animais; na Fazenda 3, três animais; na Fazenda 4, dois animais, e na Fazenda 5, cinco animais.

A análise de variância para essas variáveis comparou as médias das colheitas, admitindo o seguinte modelo com medidas repetidas no tempo:

$$
y_{i j k}=\mu+F_{i}+e_{i j}+C_{K}+(C F)_{k i}+\varepsilon_{i j k}
$$


$\mathrm{i}=1,2, \ldots 5 ; \mathrm{j}=1,2, \ldots, 8$ e $\mathrm{k}=$ abril, maio, $\ldots$ novembro

onde:

$y_{\mathrm{ijk}}=$ é a resposta da j-ésima búfala;

$\mu=$ média geral;

$\mathrm{F}_{\mathrm{i}}=$ efeito da i-ésima fazenda;

$\varepsilon_{\mathrm{ij}}=$ erro aleatório associado à parcela (ij);

$\mathrm{C}_{\mathrm{k}}=$ efeito do k-ésima colheita;

$(C F)_{i k}=$ efeito da interação do i-ésima fazenda e a k-ésima colheita;

$\varepsilon_{\mathrm{ijk}}=$ erro aleatório associado a subparcela (ijk).

Quando a interação foi significativa, realizou-se seu desdobramento para comparar as colheitas em cada fazenda. Para comparação das médias utilizouse o teste t de Student, em um nível de significância de 5\%. Quando a interação não foi significativa, as médias das colheitas foram comparadas independentemente da fazenda, pelo mesmo teste.

As análises foram feitas utilizando-se o PROC MIXED do SAS (Statistica Analysis System (SAS Institut Inc., 2004).

Devido à dificuldade em se comparar distintos sistemas de produção (desigualdade de condições), não foi apresentada a análise estatística comparando as fazendas entre si.

Devido ao grande número de variáveis, utilizou-se também o método multivariado de Análises de Componentes Principais (PCA), que tem por objetivo explicar ao máximo a variabilidade total do conjunto de variáveis originais, através das variáveis não correlacionadas, chamadas "componentes principais" que são obtidas através das matrizes de correlações entre as variáveis (Hoffmann, 1999). Nesta análise utilizou-se o programa computacional PROC PRINCCOMP do SAS (2004). 


\section{RESULTADOS E DISCUSSÃO}

\subsection{Componentes do leite}

\subsubsection{Teor de gordura no leite}

No Anexo A pode-se observar a produção de leite durante a lactação por fazenda estudada neste experimento, assim como o períod de lactação.

A percentagem média de gordura do leite foi de 7,5\%,7,2\%, 6,8\%, 6,6\% e 6,6\%, respectivamente para as Fazendas 1, 2, 3, 4 e 5 (Tabela 6). Estas médias são superiores àquelas encontradas por Faria et al. (2002). Nas fazendas 1 e 2, as médias foram superiores às encontradas por Duarte et al. (2001) e por Mesquita et al. (2002), ressalta-se que, nesses trabalhos, os sistemas de produção eram a pasto; já nas Fazendas 3, 4 e 5, as médias foram similares aos resultados encontrados por esses autores.

As Fazendas 3 e 5 não apresentaram diferença $(P>0,05)$ na percentagem de gordura entre a primeira e última colheita (Tabela 6), apesar de que, em valores absolutos, a média da última colheita (novembro) foi maior que a da primeira (abril). Nas demais fazendas, observou-se diferença $(P>0,05)$ entre a primeira colheita e última. É de se esperar que a percentagem de gordura se eleve ao longo da lactação, pois, à medida que a produção cai, ocorre elevação da concentração de alguns compostos, dentre eles a gordura. A dieta também pode alterar o teor de gordura no leite (Sutton, 1989), muito embora, provavelmente, está não é a explicação já que a dieta pouco mudou ao longo do experimento. Outro fator que pode ter elevado o teor de gordura no 
leite, é o fato de que os animais encontravam-se em balanço energético positivo (final de lactação), dessa forma, liberando energia para a síntese de gordura..

\subsubsection{Teor de proteína no leite}

A percentagem de proteína no leite também apresentou variação ao longo da lactação. No início das colheitas (abril) o teor de proteína no leite foi superior $(P>0,05)$ aos valores obtidos nos meses entre maio e agosto (Tabela 6), contudo foi similar à colheita do mês de setembro e significativamente menor que as colheitas dos meses de outubro e novembro.

Os valores médios do teor de proteína encontrados neste trabalho são similares aos publicados por Duarte et al. (2001) e por Faria et al. (2002) que foram de $4,2 \%$ e 4,5\%, respectivamente, e levemente superiores aos encontrados por Mesquita et al. (2002), cujo teor médio de proteína no leite foi de 4,0\%. A diminuição no teor de proteína no leite, no meio da lactação, provavelmente está relacionado com a produção leiteira, pois à medida que a produção aumentou o teor de proteína diminuiu significativamente, provavelmente, pelo efeito de diluição. Esse resultado foi similar ao obtido por Mesquita et al. (2002). Constatou-se que no início da lactação, houve queda acentuada no teor de proteína bruta do leite até o

terço médio da lactação e elevou-se em seguida. Estes resultados apresentaram comportamento distinto dos publicados por Bovera et al. (2001), que obtiveram respostas lineares, com a média inicial menor que a média final.

Pode-se inferir que o comportamento do teor de proteína do leite produzido parece ser uma característica da espécie, já que, mesmo sob condições distintas de manejo nutricional, os resultados obtidos para a proteína bruta do leite das diferentes fazendas avaliadas foram semelhantes (Tabela 6). 


\subsubsection{Teor de $\mathrm{N}$ uréico no leite}

O teor de $\mathrm{N}$ uréico no leite tem sido utilizado como ferramenta de diagnóstico de ineficiência no manejo nutricional. O excesso de $\mathrm{N}$ uréico excretado na urina e nas fezes de ruminantes pode provocar danos ao meio ambiente por ser fonte de poluição atmosférica e hídrica; aos animais pelos efeitos tóxicos aos tecidos reprodutivos, além das perdas econômicas envolvidas com o uso de nutrientes não utilizados pelo animal e na energia gasta para sua excreção (Jonker et al., 1998).

A percentagem de $\mathrm{N}$ uréico no leite variou ao longo da lactação (Tabela 6), provavelmente devido à oscilação da qualidade da dieta nas fazendas. Em três das cinco fazendas estudadas a oscilação foi mais ampla, com médias, ao longo da lactação, fora do intervalo recomendado como ideal por Jonker et al. (1998), que varia entre 10 e 16 mg/dL, para bovinos. Nas Fazendas 2 e 5, apesar de ter sido observada diferença significativa entre as médias, estas não estiveram fora do intervalo ideal (Jonker et al., 1998), com exceção das colheitas de setembro (Fazenda 2) e setembro e novembro (Fazenda 5). As razões para estes resultados estão relacionados, provavelmente, ao manejo nutricional adotado no período. Na Fazenda 5 a dieta fornecida estava de acordo com a produção leiteira, em que buscava-se o máximo de eficiência nutricional, enquanto nas demais fazendas, as dietas fornecidas não atendiam as exigências nutricionais. Na Fazenda 2, como já discutido anteriormente, as médias estão dentro da margem proposta por Jonker et al. (1998) para bovinos de leite, porém, foi observada maior variação, com acréscimos e decréscimos bruscos ao longo da lactação podendo-se inferir certo descontrole na dieta.

Observa-se, também, que, em todas as fazendas, nos primeiros meses da lactação (abril a junho) o teor de $\mathrm{N}$ uréico no leite estava dentro da faixa recomendada por Jonker et al. (1998) para bovinos de leite (Tabela 6). 
Tabela 6 - Teores de gordura, proteína e nitrogênio uréico no leite de búfalas ao longo da lactação

\begin{tabular}{|c|c|c|c|c|c|c|c|c|c|c|}
\hline Variáveis & Faz. & & & & & Colheitas & & & & \\
\hline & & Abril & maio & junho & julho & agosto & setembro & outubro & novembro & Média \\
\hline \multicolumn{11}{|l|}{ Gordura } \\
\hline & 1 & $5,8 \pm 0,38^{1 c}$ & $6,7 \pm 0,34^{b}$ & $7,7 \pm 0,64^{a}$ & $7,5 \pm 0,34^{a b}$ & $7,6 \pm 0,34^{a}$ & $7,5 \pm 0,34^{a b}$ & $8,4 \pm 0,34^{a}$ & $8,6 \pm 0,68^{a}$ & $7,5 \pm 0,16$ \\
\hline & 2 & $5,4 \pm 0,34^{b}$ & $7,4 \pm 0,34^{a}$ & $7,3 \pm 0,34^{a}$ & $7,4 \pm 0,34^{a}$ & $7,3 \pm 0,53^{a}$ & $7,6 \pm 0,34^{a}$ & $7,6 \pm 0,34^{a}$ & $7,7 \pm 0,48^{a}$ & $7,2 \pm 0,15$ \\
\hline & 3 & $5,9 \pm 0,40^{c}$ & $6,6 \pm 0,34^{a b c}$ & $6,8 \pm 0,34^{a b c}$ & $6,5 \pm 0,34^{b c}$ & $6,6 \pm 0,37^{a b c}$ & $7,4 \pm 0,39^{a b}$ & $7,6 \pm 0,40^{a}$ & $7,1 \pm 0,56^{a b c}$ & $6,8 \pm 0,16$ \\
\hline & 4 & $6,4 \pm 0,37^{b}$ & $6,3 \pm 0,36^{b}$ & $6,3 \pm 0,34^{b}$ & $6,1 \pm 0,34^{b}$ & $6,1 \pm 0,34^{b}$ & $6,3 \pm 0,34^{b}$ & $7,0 \pm 0,55^{a b}$ & $8,3 \pm 0,56^{\mathrm{a}}$ & $6,6 \pm 0,17$ \\
\hline & 5 & $5,7 \pm 0,34^{b}$ & $6,5 \pm 034^{a}$ & $7,3 \pm 0,34^{a}$ & $6,9 \pm 0,36^{a}$ & $6,7 \pm 0,34^{\mathrm{a}}$ & $6,4 \pm 0,34^{a b}$ & $7,0 \pm 0,34^{a}$ & $6,4 \pm 0,48^{a b}$ & $6,6 \pm 0,15$ \\
\hline \multicolumn{11}{|l|}{ Proteína } \\
\hline & 1 & $4,2 \pm 0,13^{b}$ & $4,1 \pm 0,12^{c}$ & $4,1 \pm 0,12^{c}$ & $4,0 \pm 0,12^{c}$ & $4,0 \pm 0,12^{c}$ & $4,4 \pm 0,12^{b}$ & $4,5 \pm 0,12^{a}$ & $4,5 \pm 0,24^{a}$ & $4,2 \pm 0,06$ \\
\hline & 2 & $4,3 \pm 0,12^{b}$ & $4,1 \pm 0,12^{c}$ & $4,1 \pm 0,12^{\mathrm{C}}$ & $4,2 \pm 0,12^{\mathrm{C}}$ & $4,2 \pm 0,14^{\mathrm{C}}$ & $4,3 \pm 0,12^{b}$ & $4,8 \pm 0,12^{a}$ & $4,6 \pm 0,17^{\mathrm{a}}$ & $4,3 \pm 0,06$ \\
\hline & 3 & $4,0 \pm 0,14^{b}$ & $4,0 \pm 0,12^{c}$ & $4,0 \pm 0,12^{c}$ & $3,9 \pm 0,12^{c}$ & $4,1 \pm 0,13^{c}$ & $4,4 \pm 0,14^{b}$ & $4,7 \pm 0,14^{\mathrm{a}}$ & $4,6 \pm 0,19^{a}$ & $4,2 \pm 0,06$ \\
\hline & 4 & $4,3 \pm 0,13^{b}$ & $3,8 \pm 0,13^{c}$ & $3,9 \pm 0,12^{c}$ & $3,9 \pm 0,12^{c}$ & $3,7 \pm 0,12^{c}$ & $3,9 \pm 0,12^{b}$ & $4,3 \pm 0,19^{a}$ & $4,9 \pm 0,20^{a}$ & $4,1 \pm 0,06$ \\
\hline & 5 & $4,5 \pm 0,12^{b}$ & $4,1 \pm 0,12^{c}$ & $4,1 \pm 0,12^{c}$ & $3,8 \pm 0,13^{c}$ & $4,0 \pm 0,12^{c}$ & $4,0 \pm 0,12^{b}$ & $4,2 \pm 0,12^{a}$ & $4,5 \pm 0,17^{\mathrm{a}}$ & $4,2 \pm 0,06$ \\
\hline N uréico & & & & & & & & & & \\
\hline & 1 & $16,3 \pm 0,70^{\mathrm{C}}$ & $14,8 \pm 0,79^{\mathrm{C}}$ & $14,8 \pm 0,92^{\mathrm{C}}$ & $26,1 \pm 1,37^{a}$ & $21,9 \pm 1,13^{b}$ & $27,3 \pm 1,00^{a}$ & $20,6 \pm 1,21^{b}$ & $14,1 \pm 1,58^{c}$ & $19,5 \pm 1,09$ \\
\hline & 2 & $14,6 \pm 0,66^{b c}$ & $14,6 \pm 0,82^{b c}$ & $11,1 \pm 0,94^{\mathrm{C}}$ & SI & $14,8 \pm 1,17^{\mathrm{bc}}$ & $19,3 \pm 1,02^{a}$ & $13,0 \pm 1,21^{\mathrm{c}}$ & $16,3 \pm 1,00^{b}$ & $14,8 \pm 0,97$ \\
\hline & 3 & $17,4 \pm 0,75^{\mathrm{c}}$ & $14,5 \pm 0,78^{d}$ & $13,1 \pm 0,90^{d}$ & $19,6 \pm 1,33^{b c}$ & $18,9 \pm 1,22^{b c}$ & $25,0 \pm 1,11^{a}$ & $19,5 \pm 1,20^{b c}$ & $20,6 \pm 1,43^{b}$ & $16,7 \pm 1,09$ \\
\hline & 4 & $12,7 \pm 0,70^{\mathrm{C}}$ & $12,3 \pm 0,84^{c}$ & $9,10 \pm 0,90^{d}$ & $5,9 \pm 1,33^{\mathrm{e}}$ & $9,7 \pm 1,18^{d}$ & $5,6 \pm 1,10^{\mathrm{e}}$ & $25,9 \pm 1,75^{\mathrm{a}}$ & $18,6 \pm 1,19^{b}$ & $12,8 \pm 1,13$ \\
\hline & 5 & $15,1 \pm 0,66^{b c}$ & $14,1 \pm 0,82^{\mathrm{C}}$ & $14,4 \pm 0,99^{b c}$ & $15,5 \pm 1,72^{b c}$ & $14,0 \pm 1,06^{\mathrm{c}}$ & $17,1 \pm 1,19^{b}$ & $16,1 \pm 1,21^{b c}$ & $20,6 \pm 0,90^{a}$ & $15,9 \pm 1,07$ \\
\hline
\end{tabular}

1 - erro padrão

Letras minúsculas distintas na mesma linha, representam médias diferentes $(\mathrm{P}<0,05)$

SI - sem informação 
A partir desse momento, o excesso de $\mathrm{N}$ uréico no leite começou a ser detectado, podendo-se inferir que, enquanto os animais estiveram com produções de leite mais elevadas, nos primeiros meses de lactação, mesmo com dieta desbalanceada, pode ter havido maior eficiência do uso do $\mathrm{N}$ no rúmen.

Após o início da curva descendente da produção de leite, a oferta de alimentos continuou a mesma, fazendo com que, provavelmente, houvesse excesso de amônia ruminal, provocando maior absorção desta amônia, que por sua vez, elevou o teor de $\mathrm{N}$ uréico no leite. De acordo com Nousiainen et al. (2004) a percentagem de $\mathrm{N}$ uréico no leite está mais associada à proteína bruta (PB) da dieta, do que com a relação energia/PB. É importante lembrar que o resíduo de cervejaria possui cerca de 30\% de PB na MS (Costa et al., 1994). No presente trabalho o resíduo de cervejaria foi utilizado nas dietas dos animais avaliados, como único concentrado, a exceção foi a Fazenda 5.

Os valores médios de $\mathrm{N}$ uréico no leite determinados ao longo da lactação na Fazenda 4 podem ser observados na Tabela 6. Constatou-se que, nos meses de abril e maio, os valores estavam dentro das recomendações de Jonker et al. (1998), contudo, a partir de junho os níveis tenderam a decrescer, chegando a 5,6 mg/dL em setembro e voltando a se elevar em outubro e novembro. A possível explicação para este fato é que, a partir do mês de maio, houve interrupção no fornecimento do resíduo de cervejaria, permanecendo apenas as pastagens e silagens de milho e outras gramíneas. Nesse período, as pastagens entraram em processo de estresse (baixas temperaturas, luminosidade e umidade) e, consequentemente, diminuição na disponibilidade e qualidade, o que levou os animais a diminuírem seu escore corporal. Segundo Van Soest (1994) a baixa ingestão de nitrogênio provoca melhoria na eficiência de sua reciclagem, com isso, a excreção de $\mathrm{N}$ uréico diminui.

Pesquisas mostram que até a quinta semana de lactação, em dietas balanceadas, bovinos leiteiros podem perder mais de $50 \mathrm{~kg}$ de gordura de reserva e até $12 \mathrm{~kg}$ de reservas protéicas. Após este período, não é mais 
observada mobilização de proteína corporal (fonte de reciclagem de nitrogênio no organismo), diminuindo, assim, uma das fontes de $\mathrm{N}$ uréico ruminal (Komaragiri et al., 1998; Dijkstra et al., 1998).

Ainda na Tabela 6, pode-se observar que como média geral por fazenda, o teor de $\mathrm{N}$ uréico no leite esteve sempre na margem sugerida como ideal por Jonker et al. (1998), porém a avaliação ao longo da lactação demonstrou a existência de variação fora dos limites sugeridos por estes autores.

A percentagem média da $\mathrm{N}$ uréico no leite de búfalas deste estudo difere bastante dos valores publicados por Campanile et al. (1998) e Bovera et al. (2001). Estes autores desenvolveram estudos, na Itália, avaliando a influência do teor de proteína bruta da dieta (9 e 12\%) sobre o teor de $\mathrm{N}$ uréico no leite, encontraram médias variando entre 28,5 e $37,3 \mathrm{mg} / \mathrm{dL}$, distintas dos valores obtidos no presente trabalho.

\subsubsection{Teor de sólidos totais}

Em relação ao teor de sólidos totais, com exceção da Fazenda 5, todas as fazendas apresentaram diferença significativa entre as médias da primeira e última colheita, sendo a última sempre maior (Tabela 7). Na maioria das colheitas, as médias obtidas no teor de sólidos totais na Fazenda 5 foram sempre menores que as demais fazendas, porém, nos meses de junho, julho e agosto foram observados os menores teores de sólidos totais no leite, provavelmente pelo maior nível de produção de leite das búfalas, sendo, portanto um reflexo mais ligado ao efeito de concentração, ou seja, relação do teor de água com os sólidos do leite.

O teor de sólidos totais obtido foi similar aos resultados obtidos por diversos autores em bubalinos, em trabalhos realizados no Brasil e no exterior conforme pode-se comparar observando-se as Tabelas 1 e 7 (NRC, 1981; Duarte et al., 2001; Mesquita et al., 2001; Faria et al., 2002). 
Tabela 7 - Teores de sólidos totais e lactose no leite de búfalas ao longo da lactação

\begin{tabular}{|c|c|c|c|c|c|c|c|c|c|c|}
\hline Variáveis & Faz. & \multicolumn{9}{|c|}{ Colheitas } \\
\hline & & abril & maio & junho & julho & agosto & setembro & outubro & novembro & Média \\
\hline \multicolumn{11}{|c|}{ Sólidos totais } \\
\hline & 1 & $16,0 \pm 0,44^{1 \mathrm{c}}$ & $17,3 \pm 0,42^{b}$ & $18,0 \pm 0,44^{\text {bd }}$ & $18,1 \pm 0,42^{\mathrm{bd}}$ & $18,2 \pm 0,41^{\mathrm{abd}}$ & $18,1 \pm 0,41^{\mathrm{abd}}$ & $19,2 \pm 0,41^{\mathrm{a}}$ & $19,3 \pm 0,82^{\mathrm{a}}$ & $18,0 \pm 0,21$ \\
\hline & 2 & $15,8 \pm 0,41^{b}$ & $17,9 \pm 0,41^{\mathrm{a}}$ & $18, \pm 0,41^{a}$ & $18, \pm 0,41^{\mathrm{a}}$ & $17,7 \pm 0,47^{\mathrm{a}}$ & $18,1 \pm 0,41^{\mathrm{a}}$ & $18,6 \pm 0,41^{\mathrm{a}}$ & $18,3 \pm 0,58^{a}$ & $17,8 \pm 0,20$ \\
\hline & 3 & $16,1 \pm 0,48^{\mathrm{c}}$ & $17,0 \pm 0,41^{\text {bc }}$ & $17,2 \pm 0,41^{\text {bc }}$ & $16,9 \pm 0,41^{\mathrm{bc}}$ & $17,1 \pm 0,44^{\mathrm{bc}}$ & $17,9 \pm 0,47^{\mathrm{ab}}$ & $18,5 \pm 0,48^{a}$ & $17,5 \pm 0,67^{\mathrm{ab}}$ & $17,3 \pm 0,21$ \\
\hline & 4 & $16,7 \pm 0,44^{b}$ & $16,8 \pm 0,44^{b}$ & $17,0 \pm 0,42^{b}$ & $17,0 \pm 0,42^{b}$ & $16,5 \pm 0,42^{b}$ & $16,8 \pm 0,42^{b}$ & $17,6 \pm 0,67^{a}$ & $19,0 \pm 0,67^{a}$ & $17,2 \pm 0,21$ \\
\hline & 5 & $16,1 \pm 0,42^{b}$ & $15,1 \pm 0,42^{b c}$ & $14,0 \pm 0,42^{c}$ & $15,0 \pm 0,44^{\mathrm{bc}}$ & $17,2 \pm 0,42^{\mathrm{ab}}$ & $16,6 \pm 0,42^{\mathrm{ab}}$ & $17,4 \pm 0,42^{\mathrm{a}}$ & $16,6 \pm 0,58^{\mathrm{ab}}$ & $16,0 \pm 0,19$ \\
\hline \multicolumn{11}{|l|}{ Lactose } \\
\hline & 1 & $5,1 \pm 0,08^{\mathrm{abc}}$ & $5,2 \pm 0,08^{a}$ & $5,2 \pm 0,08^{a b}$ & $5,2 \pm 0,08^{\mathrm{ab}}$ & $5,2 \pm 0,08^{a b}$ & $4,9 \pm 0,08^{\mathrm{C}}$ & $5,0 \pm 0,08^{b c}$ & $4,7 \pm 0,16^{c}$ & $5.1 \pm 0.18$ \\
\hline & 2 & $4,8 \pm 0,08^{a}$ & $5,1 \pm 0,08^{a}$ & $5,1 \pm 0,08^{a}$ & $5,0 \pm 0,08^{a}$ & $4,9 \pm 0,10^{a}$ & $4,9 \pm 0,08^{a}$ & $4,8 \pm 0,08^{a}$ & $4,7 \pm 0,11^{a}$ & $4.9 \pm 0.15$ \\
\hline & 3 & $5,0 \pm 0,10^{b c}$ & $5,2 \pm 0,08^{\mathrm{ab}}$ & $5,0 \pm 0,08^{b c}$ & $5,3 \pm 0,08^{a}$ & $5,0 \pm 0,09^{b c}$ & $4,8 \pm 0,10^{\mathrm{cd}}$ & $4,9 \pm 0,10^{\mathrm{bc}}$ & $4,5 \pm 0,13^{d}$ & $5.0 \pm 0.24$ \\
\hline & 4 & $4,8 \pm 0,08^{b c}$ & $5,3 \pm 0,09^{a b}$ & $5,4 \pm 0,08^{\mathrm{ab}}$ & $5,6 \pm 0,08^{a}$ & $5,4 \pm 0,08^{a}$ & $5,4 \pm 0,08^{a}$ & $5,1 \pm 0,13^{b}$ & $4,5 \pm 0,14^{c}$ & $5.2 \pm 0.36$ \\
\hline & 5 & $4,6 \pm 0,08^{d}$ & $5,2 \pm 0,08^{a}$ & $5,1 \pm 0,09^{\mathrm{ab}}$ & $5,0 \pm 0,09^{\mathrm{abc}}$ & $5,1 \pm 0,08^{\mathrm{ab}}$ & $4,9 \pm 0,08^{c}$ & $4,8 \pm 0,08^{\mathrm{c}}$ & $4,5 \pm 0,11^{d}$ & $4.9 \pm 0.09$ \\
\hline
\end{tabular}

1 - erro padrão

Letras minúsculas distintas na mesma linha, representam médias diferentes $(P<0,05)$ 


\subsubsection{Teor de lactose}

O teor de lactose no leite apresentou elevação à medida que a produção aumentou, o que é esperado, devido à sua relação com a regulação da pressão osmótica na glândula mamária, visto que a lactose responde por, aproximadamente, $50 \%$ da pressão osmótica do leite, o restante é exercido pelo citrato, íons, proteínas, etc. (Tabela 7). A percentagem média de lactose no leite encontrada foi similar aos resultados publicados por Duarte et al. (2001) e Mesquita et al. (2002). O pico da lactose acompanhou a curva de lactação.

$\mathrm{O}$ teor de lactose correlacionou-se negativamente com o teor de gordura $(-0,40)$, proteína $(0,55)$ e, consequentemente, com o teor de sólidos totais (0,30 ), este, por usa vez, correlacionou-se positivamente com o teor de gordura no leite $(0,84)$ e proteína $(0,46)$.

\subsection{Os ácidos graxos}

\subsubsection{Nos alimentos}

O teor de lipídeos variou de acordo com a estação do ano para as duas gramíneas estudadas. Na B. decumbens, o teor cresceu 48,2\% de julho para novembro, enquanto que na $B$. ruziziensis, o crescimento foi de $42,8 \%$ (Tabela 8). Os dados comprovam que o período seco (inverno) atua negativamente sobre a fração lipídica das plantas forrageiras. Diversos autores observaram este efeito em plantas de clima temperado e tropical (O'Kelly \& Reich 1976; Dewhurst et al., 2002; French et al., 2000). Isto se deve ao fato de que o percentual de tecido não ativo metabolicamente (senescente), aumenta em

função do estágio de desenvolvimento da planta, visto que ocorre aumento do teor de fibra e diminuição da proporção de folhas (Dewhurst et al., 2001, GuilGuerrero et al., 2001). 
A B. ruziziensis apresentou menor queda no teor de lipídeos que a $B$. decumbens (pastejo contínuo sem adubação), provavelmente devido ao manejo dispensado à $B$. ruziziensis, que consistiu de pastejo rotacionado (intervalo de 30 dias), com adubação após o pastejo. O corte freqüente na $B$. ruziziensis proporcionou novo período de crescimento vegetativo, sem emissão de inflorescência e elongamento de haste, com isso, provavelmente, a relação folha/caule pode ter sido aumentada. Como em plantas forrageiras os ácidos graxos concentram-se principalmente nas folhas, é de se esperar que manejo que aumente a relação folha/caule proporcione, consequentemente, maior teor de lipídeos nestas plantas.

Dessa forma, os resultados deste estudo corroboram os dados publicados por Dewhurst et al. (2002) que afirmam que o corte, em intervalos menores, provoca mudanças fisiológicas na planta, determinando a não emissão da inflorescência, que atua diminuindo a relação folha/caule, com conseqüente diminuição da concentração de ácidos graxos nas forrageiras.

A composição média da fração lipídica das forrageiras sofre mudanças substanciais, de acordo com a estação do ano. Vários autores confirmam esta informação, dentre eles Elgersma et al. (2003), Dewhurst et al. (2002), French et al. (2000) e O’Kelly \& Reich (1976) (Tabela 3).

Nas plantas, os ácidos graxos encontram-se nos tecidos metabolicamente ativos, principalmente nas folhas. As plantas apresentam estrutura que muda de acordo com as condições climáticas, com isso, no inverno, as plantas forrageiras entram em estresse (baixa temperatura, luminosidade e precipitação) por sua vez, o percentual de material senescente aumenta e diminui as folhas ativas. O teor de ácidos graxos também apresenta queda, principalmente os insaturados como o linoléico e $\alpha$-linolênico (Dewhurst et al., 2001), provocando queda em sua disponibilidade no rúmen. Como conseqüência dessa menor disponibilidade no rúmen de substrato (ácido linoléico e $\alpha$-linolênico) para a biohidrogenação o teor de CLA no leite 
apresenta diminuição, obviamente quando não há outra fonte na dieta dos ácidos linoléico e $\alpha$-linolênico.

O teor de ácido linoléico na $B$. decumbens no período seco foi de $18,2 \%$ dos ácidos graxos detectados, sofrendo ligeiro aumento no período das águas, alcançando 19,9\%. O teor de ácido linoléico, no inverno, foi menor que o encontrado por O'Kelly \& Reich (1976), enquanto no verão foi similar ao encontrado por esses autores que avaliaram o C. gayana. $O$ teor de ácido linolênico se elevou de 20,8\%, no período seco, para 31,4\% no período das águas, acréscimo de aproximadamente 34\%. Estes dois ácidos graxos (linoléico e linolênico) totalizaram $51,3 \%$ no período das águas, e 39,0\% no período seco para $B$. decumbens, enquanto os demais ácidos graxos apresentaram decréscimo em seu teor em novembro, em relação à julho (Tabela 8).

Tabela 8 - Composição da fração lipídica e ácidos graxos das plantas forrageiras tropicais, com base na matéria seca

\begin{tabular}{|c|c|c|c|c|}
\hline \multirow[t]{2}{*}{ Variáveis } & \multicolumn{2}{|c|}{ B. decumbens ${ }^{1}$} & \multicolumn{2}{|c|}{ B. ruziziensis ${ }^{2}$} \\
\hline & julho & novembro & julho & Novembro \\
\hline $\mathrm{EE}(\%)$ & $1,13 \pm 0,46$ & $2,18 \pm 0,28$ & 2,10 & 3,67 \\
\hline MS (\%) & 33,7 & 24,6 & 31,5 & 12,8 \\
\hline Ácidos graxos ${ }^{4}$ & & & & \\
\hline $\mathrm{C}_{14: 0}$ & 2,7 & 1,2 & 0,7 & 1,3 \\
\hline $\mathrm{C}_{16: 0}$ & 37,0 & 33,6 & 21,2 & 26,2 \\
\hline$C_{16: 1 c 9}$ & 1,3 & 0,7 & 0,7 & 0,2 \\
\hline $\mathrm{C}_{18: 0}$ & 7,5 & 5,8 & 2,4 & 3,9 \\
\hline $\mathrm{C}_{18: 1 \mathrm{c} 9}$ & 10,2 & 5,4 & 6,6 & 2,6 \\
\hline $\mathrm{C}_{18 \mathrm{:} 2 \mathrm{c} 9 \mathrm{c} 12}$ & 18,2 & 19,9 & 17,7 & 19,4 \\
\hline $\mathrm{C}_{18: 3}$ & 20,8 & 31,4 & 50,2 & 45,6 \\
\hline $\mathrm{C}_{20: 0}$ & 2,3 & 1,9 & 0,7 & 0,9 \\
\hline
\end{tabular}

1 - em julho, média de duas fazendas, em cinco amostras; em novembro média de duas amostras, sob pastejo contínuo sem adubação; 2 - amostragem única de $B$. ruziziensis para cada período, sob pastejo rotacionado (30 dias de intervalo) com adubação; 4 - total dos ácidos graxos identificados

A B. ruziziensis (BR) apresentou resultado diferente do capim $B$. decumbens. Os ácidos mirístico, palmítico, esteárico e linoléico, apresentaram 
leve aumento em seus teores em novembro, em relação à julho, enquanto os demais ácidos graxos apresentaram redução. O ácido linolênico apresentou redução em novembro quando comparado à julho, contudo apresentou grande participação no total de ácidos graxos (45,6\%) e juntamente com o linoléico, totalizaram 67,9\% em julho, e 65,0\% em novembro (Tabela 8).

A redução no intervalo de corte e o adequado manejo de fertilização da $B$. ruziziensis, em relação à $B$. decumbens, fizeram com que as plantas modificassem a estrutura do dossel, o que garantiu-Ihes persistência no período seco. Dessa forma, os tecidos metabolicamente ativos, provavelmente, apresentaram participação maior no dossel, fazendo com que os ácidos graxos, principalmente os polinsaturados, não sofressem queda substancial, concordando, assim, com os resultados encontrados por Dewhurst et al. (2002), que não encontraram mudança no perfil de ácidos graxos nas pastagens avaliadas quando o intervalo de corte foi menor, provocado pela maior relação folha/caule. De acordo com Hawke (1973) os ácidos graxos, em vegetais, concentram-se nos tecidos fotossintéticos (cloroplastos), dessa forma, se há diminuição das folhas ou estas secam (senescência) o teor de ácidos graxos diminui.

Os dados aqui apresentados (Tabela 8) corroboram os resultados publicados por Dewhurst et al. (2001), que observaram que, quando ocorre diminuição no teor de lipídeos das forrageiras, os ácidos graxos mais atingidos são os polinsaturados (linoléico e linolênico). No entanto, deve-se levar em consideração o manejo aplicado à planta, pois intervalos de corte que provoquem novo período de crescimento, produzem efeitos benéficos sobre o teor de ácidos graxos polinsaturados (Tabela 3).

O teor de ácido linolênico, nas plantas forrageiras tropicais discutidas neste trabalho, foram menores que os publicados por Elgersma et al. (2003), Dewhurst et al. (2002), Dewhurst et al. (2001) e French et al. (2000), que avaliaram plantas forrageiras de clima temperado, independente da espécie e manejo aplicado. Entretanto, o teor do ácido linolênico na $B$. ruziziensis, foi 
similar ao resultado encontrado por French et al. (2000) em gramíneas de clima temperado e foi superior ao resultado publicado por O'Kelly \& Reich (1976) em gramíneas de clima tropical.

De forma geral, gramíneas de clima tropical possuem menores teores de ácidos graxos polinsaturados e maiores teores de ácido palmítico que gramíneas de clima temperado, isto se deve, provavelmente, à fatores adaptativos, visto que o ponto de fusão dos ácidos graxos presentes nas membranas celulares irá determinar sua maior ou menor resistência à temperatura (alta ou baixa), Então, como os ácidos graxos polinsaturados possuem baixo ponto de fusão (Tabela 2), as plantas forrageiras de clima temperado enfrentam as baixas temperaturas, sem sofrerem grandes injúrias celulares determinadas pelo frio, enquanto em plantas de clima tropical, ocorre elevação nos teores de ácido palmítico como solução contra alterações de fluidez das membranas celulares (Hopkins, 1995).

A percentagem de extrato etéreo do resíduo de cervejaria (Tabela 9) foi mais elevado para a Fazenda 3, cujo teor médio esteve acima de 11\%, não sendo observada variação de acordo com o período do ano. Nas Fazendas 1 e 2 houve diminuição no teor de extrato etéreo do resíduo de cervejaria no mês de julho em relação ao mês de novembro; nas Fazendas 3 e 4 foi observada variação no teor de extrato etéreo, havendo menor teor em novembro que em julho.

Em julho, o teor de extrato etéreo do resíduo de cervejaria ofertado na Fazenda 3 foi maior que nas demais fazendas, com a diferença variando entre 18 e 35\%; em novembro, também foi observada variação positiva entre 24 e $39 \%$ (Tabela 9).

O resíduo de cervejaria apresentou perfil de ácidos graxos com pouca variação entre períodos do ano, em três, das cinco fazendas avaliadas. Entre os ácidos graxos, destaca-se o ácido linoléico com maior participação no teor de lipídeos (Tabela 9). Os dados de literatura sobre o perfil de ácidos graxos em 
resíduo de cervejaria são raros ou inexistentes, o que dificulta a obtenção de parâmetros comparativos.

Conforme pode-se observar na Tabela 9, o teor de matéria seca do resíduo de cervejaria variou, isso se deve ao manejo aplicado à este de acordo com a fazenda. Na Fazenda 1 o resíduo de cervejaria que chegava era depositado em silo, dessa forma o excesso de umidade escorria, determinando, assim, maior teor de matéria seca. Nas Fazendas 2, 3 e 4 o resíduo de cervejaria, ao chegar, era diluído, com isso o teor de matéria seca diminuía; enquanto na Fazenda 5 o resíduo de cervejaria era fornecido na mesma forma em que chegava à fazenda.

A média de matéria seca do resíduo de cervejaria observado por Costa et al. (1994) foi de 15,5\%, assim, as Fazendas 2 e 4 em julho apresentaram menor teor, enquanto as Fazendas 1, 3 e 5, apresentaram teor superior ao observado por estes autores. Em novembro o teor de matéria seca do resíduo de cervejaria observado foi superior à média observada por Costa et al. (1994), com exceção das Fazendas 3 e 4.

Tabela 9 - Composição da fração lipídica do resíduo de cervejaria de acordo com o período do ano e por fazenda

\begin{tabular}{|c|c|c|c|c|c|c|c|c|}
\hline Fazenda & Época & MS & EE & & & cidos gr & 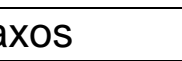 & \\
\hline & & & & $\mathrm{C}_{16: 0^{1}}$ & $\mathrm{C}_{18: 0}$ & $\mathrm{C}_{18: 1 \mathrm{c} 9}$ & $\mathrm{C}_{18: 2 \mathrm{c} 9 \mathrm{c} 12}$ & $\mathrm{C}_{18: 3}$ \\
\hline 1 & julho & 26,7 & 7,5 & 26,7 & 1,8 & 14,8 & 51,9 & 4,5 \\
\hline & novembro & 37,1 & 8,9 & 28,4 & 2,3 & 13,3 & 50,4 & 4,8 \\
\hline 2 & julho & 10,1 & 7,6 & 41,0 & 3,0 & 18,3 & 34,4 & 2,0 \\
\hline & novembro & 19,5 & 8,9 & 31,0 & 2,0 & 11,2 & 50,1 & 5,0 \\
\hline 3 & julho & 16,3 & 11,6 & 26,4 & 2,0 & 15,4 & 51,7 & 4,4 \\
\hline & novembro & 16,5 & 11,7 & 29,9 & 2,3 & 12,9 & 49,1 & 4,5 \\
\hline 4 & julho & 12,8 & 9,5 & 22,1 & 5,8 & 28,3 & 39,1 & 3,1 \\
\hline & novembro & 14,1 & 7,1 & 28,4 & 1,9 & 13,6 & 51,7 & 4,3 \\
\hline 5 & julho & 23,1 & 9,1 & 27,1 & 2,0 & 14,3 & 51,0 & 4,7 \\
\hline & novembro & 22,4 & 8,2 & 27,3 & 2,0 & 15,3 & 51,3 & 3,9 \\
\hline
\end{tabular}

1 - os ácidos graxos estão expressos em percentagem do total dos lipídeos 
Na Fazenda 2 o teor de ácido linoléico no mês de julho foi 31\% menor que no mês de novembro, e na fazenda 4 , foi $24 \%$ menor no mês de julho (Tabela 9).

Pelos resultados apresentados na Tabela 9 foi constatado elevado teor de ácido linoléico em resíduo de cervejaria, subproduto muito utilizado na alimentação animal.

Na Tabela 10, estão apresentados os teores médios dos ácidos graxos de outros alimentos utilizados nas fazendas estudadas nesse experimento. $\mathrm{O}$ Bariri, uma varredura de indústria beneficiadora de grãos, destaca-se como fonte de ácido linoléico.

A polpa cítrica apresenta valores elevados de ácidos linoléico e linolênico, perfazendo um total de mais de $60 \%$ dos ácidos graxos. A cana-deaçúcar e o capim-elefante apresentaram teores elevados dos ácidos linoléico e linolênico, que, somados totalizam 58,8\% e 55,7\%, respectivamente, no entanto, o teor de extrato etéreo observado nestas gramíneas (cana-de-açúcar e capim-elefante) foi muito baixo ( $0,8 \%$ e $1,9 \%$, respectivamente). Dessa forma, na prática, estes alimentos fornecem pouco lipídeo para uso animal.

Tabela 10 - Composição percentual da fração lipídica de alimentos utilizados em dietas para bubalinos nas fazendas estudadas

\begin{tabular}{|c|c|c|c|c|c|c|c|c|}
\hline \multirow[t]{3}{*}{ Alimentos } & MS & EE & \multicolumn{6}{|c|}{ Ácidos graxos } \\
\hline & & & $C_{16: 0}$ & $\mathrm{C}_{16: 1 \mathrm{c} 9}$ & $\mathrm{C}_{18: 0}$ & $\mathrm{C}_{18: 1 \mathrm{c} 9}$ & $\mathrm{C}_{18: 2 \mathrm{c} 9 \mathrm{c} 12}$ & $\mathrm{C}_{18: 3}$ \\
\hline & 89,2 & 4,4 & 27,4 & 0,1 & 2,1 & 13,3 & 49,9 & 4,4 \\
\hline Polpa cítrica & 77,3 & 2,5 & 26,8 & 0,3 & 2,7 & 4,9 & 21,9 & 41,5 \\
\hline Cana-de-açúcar & 25,9 & 0,8 & 27,1 & 0,2 & 2,4 & 9,1 & 35,9 & 22,9 \\
\hline C. Elefante ${ }^{1}$ & 16,6 & 1,9 & 25,3 & 0,8 & 5,8 & 5,7 & 18,7 & 37,0 \\
\hline Sil. de milho ${ }^{2}$ & 29,3 & 2,1 & 23,8 & 0,7 & 5,6 & 24,6 & 34,3 & 4,7 \\
\hline
\end{tabular}

1 - C. Elefante - Pennisetum purpureum; 2 - Zea mays 
4.2.2 No leite bubalino

\subsubsection{Teor de CLA}

\subsection{Variação individual}

O teor de CLA no leite apresenta grande variação entre animais sob as mesmas condições de manejo e alimentação (Figuras 3 e 4). 


\section{Fazenda 1}

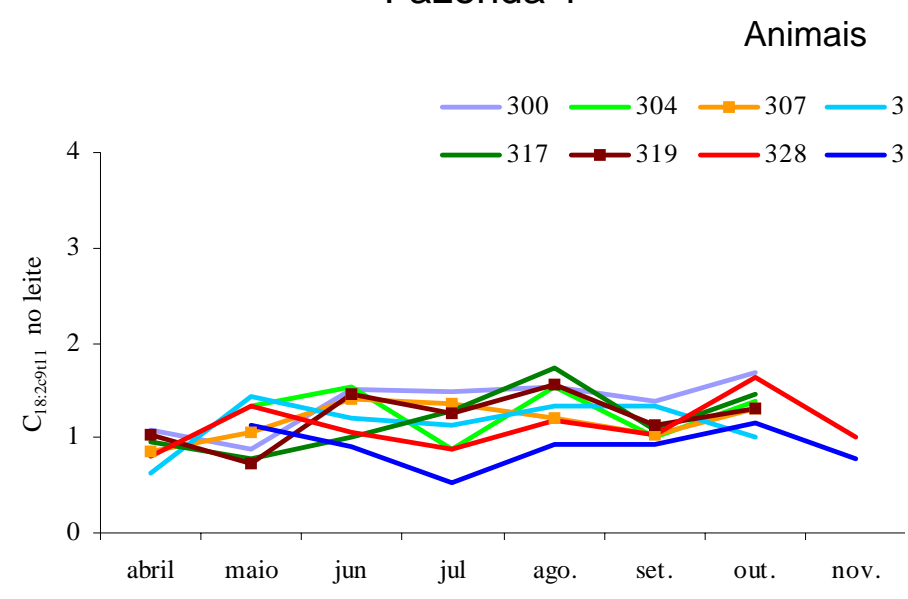

\section{Fazenda 2}

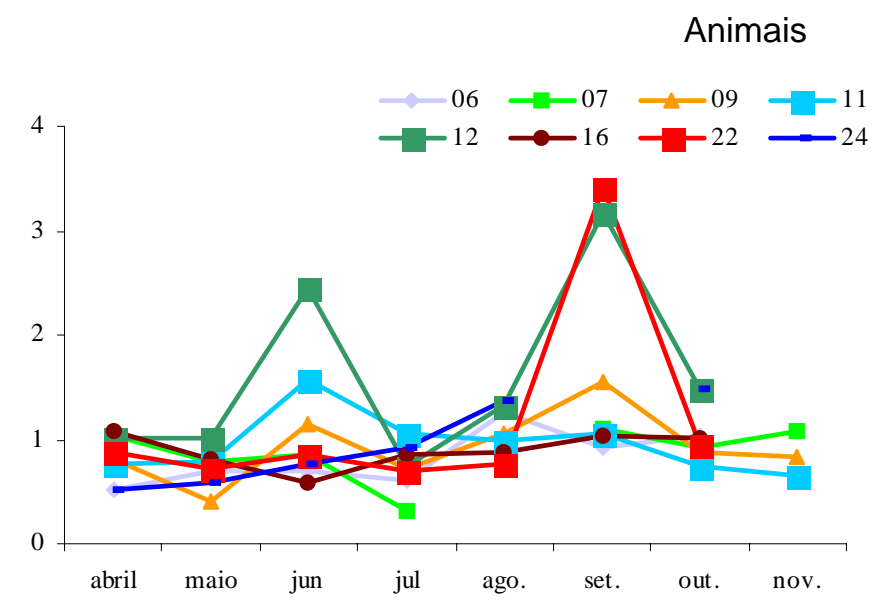

Figura 3 - Variação no teor de CLA no leite de búfalas confinadas
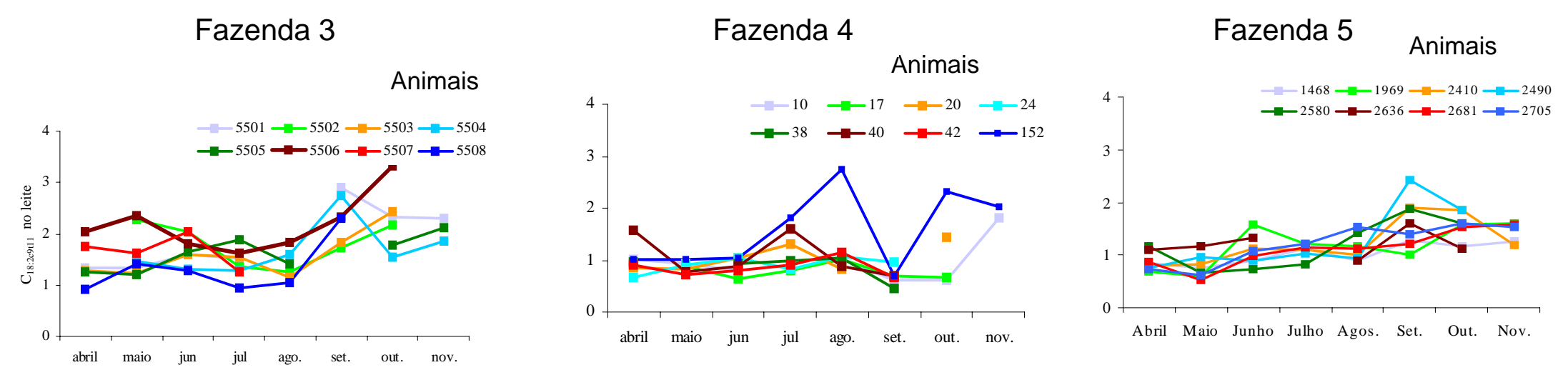

Figura 4 -Variação no teor de CLA no leite de búfalas a pasto 
Essa variação está relacionada com a absorção, no trato gastrointestinal, do ácido vacênico $\left(\mathrm{C}_{18: 1111}\right)$ produzido no rúmen, com diferenças no acúmulo de CLA no rúmen, e com a atividade da enzima $\Delta^{9}$-dessaturase na glândula mamária (Lawless et al., 1998; Bauman, 2003; Fievez et al. 2003). Os dois primeiros fatores (absorção do ácido vacênico no trato gastro-intestinal e acúmulo de CLA no rúmen) estão relacionados ao ambiente ruminal e à digesta, que podem afetar a microbiota ruminal, e, conseqüentemente, a biohidrogenação. Nesse sentido, fatores como freqüência de ruminação e salivação podem interferir no ambiente ruminal, favorecendo determinadas populações bacterianas.

A atividade da enzima $\Delta^{9}$-dessaturase torna-se importante pelo fato de ser a glândula mamária o local onde esta enzima possui maior atividade, o que a torna responsável pela maior parte do CLA presente no leite em dietas em que o teor de ácido linolênico é mais elevado (Holman \& Mahfouz, 1980; Bauman et al., 1999).

Portanto, os fatores genéticos podem explicar as diferenças na atividade da $\Delta^{9}$-dessaturase entre animais sob as mesmas condições de ambiente e de dieta. Dessa maneira, a diferença na produção de CLA entre rebanhos é esperada. Reil (1963) estudando rebanhos canadenses, comprovou essa diferença, no entanto, Kelly et al. (1998) foram os primeiros autores a publicarem artigo comprovando a variação individual na produção de CLA, sob as mesmas condições dietéticas, fato também comprovado por Lawless et al. (1998).

Kelly et al. (1998), além da comprovação da variação individual no teor de CLA no leite, observaram maior variação no teor de CLA no leite quando os animais foram submetidos a dietas em que forrageiras frescas estiveram presentes. Contudo, esses autores constataram que para animais confinados (controle) a variação no teor de CLA no leite foi entre 2,4 e 7,0 mg/g de gordura enquanto que aqueles em pastejo apresentaram intervalo mais amplo, de 6,3 a $18,1 \mathrm{mg} / \mathrm{g}$ de gordura. Estes autores concluíram que animais submetidos a 
dieta com gramíneas frescas apresentam maior variação nos teores de CLA no leite. Valores esses que ficaram bem abaixo dos apresentados no presente experimento (Tabela 11).

A variação na produção individual de CLA no leite, observada neste experimento, pode ser observada na Figura 3, para as fazendas em que os animais eram confinados e na Figura 4 para aquelas em que o sistema de produção era em pasto. Na Fazenda 1, a variação individual na produção de CLA no leite foi entre 0,52 e $1,74 \%$ da gordura do leite; na Fazenda 2, a variação foi bem maior, 0,31 a $3,42 \%$ da gordura do leite (Figura 3). Na Fazenda 1, o volumoso utilizado era, exclusivamente de silagem de milho sem espiga, enquanto na Fazenda 2, a dieta era composta por silagem de milho e gramíneas frescas, como capim-elefante fornecidas no cocho.

Na Fazenda 2 a variação do teor de CLA foi bem mais ampla. Pode-se inferir que o efeito de gramíneas frescas na dieta provoca maior variação na produção individual de CLA no leite de búfalas, como também observado por Kelly et al. (1998).

O comportamento individual do teor de CLA no leite em búfalas em pastejo pode ser visualizado na Figura 4. Na Fazenda 3 a variação no teor de CLA na gordura do leite se deu entre 0,91 e 3,31\%; na Fazenda 4 variou entre 0,44 e 2,74\%; e na Fazenda 5 os valores ficaram entre 0,53 e 2,43\% da gordura do leite.

Dentre as cinco fazendas estudadas a que apresentou menor amplitude de variação no teor de CLA no leite foi a Fazenda 1 (Figura 3), em que as búfalas eram confinadas, sem acesso a pastagens e dieta estável ao longo do ano.

Os ácidos graxos polinsaturados, principalmente o ácido linoléico e linolênico, são importantes por servirem de substrato para a biohidrogenação ruminal (Lawless, et al., 1998). Dessa forma, o sistema de produção animal exerce papel fundamental sobre a produção de CLA. 


\subsection{Variação no teor de CLA no leite de acordo com o período do ano}

Ao se comparar as médias do teor de CLA entre estações do ano são esperados diferenças significativas, devido às influências climáticas sobre as plantas, principal alimento em ruminantes, assim como, as mudanças fisiológicas destas (Lock \& Garnsworthy, 2003). Através da Figura 5 é possível observar os efeitos das épocas do ano sobre o teor de CLA no leite de búfalas, em cada Fazenda estudada. As médias de CLA nos meses de julho $(1,12 \%)$ e novembro $(0,97 \%)$ da Fazenda 1 não apresentaram diferenças estatísticas significativas (Tabela 11), apesar de ter sido observada diminuição no teor de CLA no leite, em novembro. A Fazenda 2 apresentou diferença significativa entre as médias das estações do ano. Em julho (seca) a média foi 0,73\% da gordura do leite, menor que a de novembro (águas), que foi de $1,32 \%$ da gordura do leite. A possível explicação é que, no mês de julho, nesta fazenda, as búfalas não receberam resíduo de cervejaria, e em novembro voltaram a recebe-lo, é importante lembrar que esse subproduto é uma importante fonte de ácido linoléico e em conjunto com o pasto podem ter proporcionado, as respostas apresentadas.

Também foi observada diferença $(P>0,05)$ entre as estações do ano na Fazenda 3 para o teor de CLA. Em julho, o teor médio de CLA no leite foi de $1,44 \%$, e em novembro $2,09 \%$, com superioridade de cerca $31 \%$ no mês de novembro.

Na Fazenda 4, o teor de CLA no leite em julho foi de 1,16\% e em novembro foi de $1,57 \%$, não se observando diferença significativa entre as épocas do ano. Na Fazenda 5 foi de 1,10\% e 1,46\% em julho e novembro, respectivamente, também não se observando diferença significativa. Normalmente, são esperadas diferenças significativas entre médias de épocas distintas (inverno $x$ verão), pois à medida que se eleva a participação das pastagens na dieta, se eleva, também, o teor de CLA no leite, no entanto, o uso 
do resíduo de cervejaria pode ter provocado a inexistência de diferenças significativas em algumas fazendas.

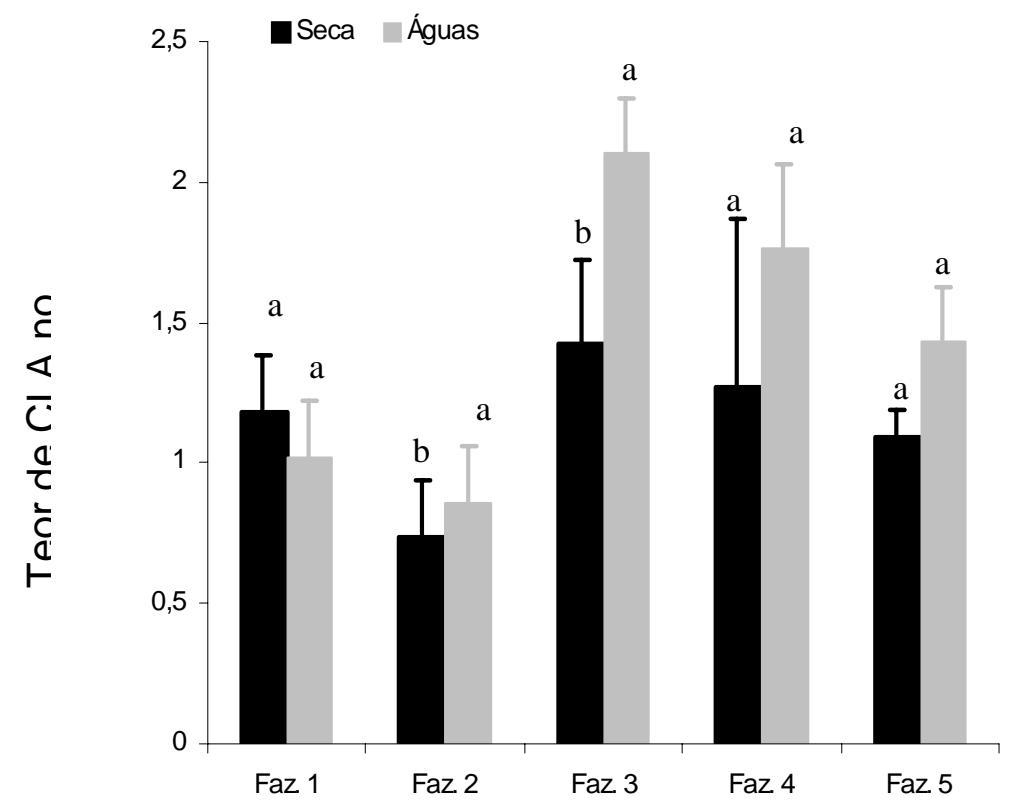

figura 5 - Efeito de estação do ano (seca x águas) sobre o teor de CLA no leite de búfalas

\subsection{Teor de CLA no leite ao longo do ano}

Na Tabela 11, pode-se observar o comportamento dos valores médios de CLA ao longo do ano de acordo com as distintas fazendas.

Em todas as fazendas estudadas houve efeito de colheita ao longo do ano sobre o teor de CLA no leite, mesmo nos sistemas onde as búfalas eram confinadas como na Fazenda 1. Nesta fazenda, não houve explicação direta para as diferenças encontradas, pois a alimentação foi constante durante o período de colheita. No entanto, pode-se dizer que o efeito animal (genético) foi mais evidenciado.

$\mathrm{Na}$ Fazenda 2, o maior teor médio de CLA no leite foi observado em setembro (1,74\% da gordura do leite) que diferiu de todas as demais colheitas, com exceção da colheita de novembro. A menor média foi observada em julho 
$(0,73 \%$ na gordura do leite) em que o resíduo de cervejaria não fez parte da dieta. Na colheita de leite de setembro, o resíduo de cervejaria fez parte da dieta juntamente com o resíduo de varredura de grãos (Bariri), outra fonte de ácido linoléico (Tabela 11) o que pode ter produzido o efeito significativo observado.

Em todas as colheitas a Fazenda 3 apresentou os maiores teores de CLA no leite (Tabela 11). Os maiores teores médios de CLA na gordura do leite de búfalas observados nessa fazenda foram 2,42\%, 2,30\% e 2,10\% para os meses de outubro, setembro e novembro, respectivamente. Esses valores chamam a atenção por serem superiores aos obtidos pelas outras fazendas, para os mesmos meses, além de serem maiores que os relatados para bovinos. A possível explicação para estes resultados é o teor de extrato etéreo do resíduo de cervejaria utilizado nesta fazenda, que foi superior ao teor médio nas demais fazendas, fornecendo, dessa forma, mais substrato para a biohidrogenação ruminal.

Alimentos com elevados teores em ácido linoléico proporcionam a elevação do teor de CLA no leite, por determinar a elevação da absorção de CLA ( $\left.C_{18: 2 c 9 t 11}\right)$ produzido pela isomerização inicial (no rúmen) do ácido linoléico.

Quando a dieta é rica em ácido linoléico a proporção deste isômero de CLA ( $\left.C_{18: 2 c 9 t 11}\right)$ no rúmen se eleva bem como sua absorção no trato gastrointestinal, consequentemente, a proporção de CLA pré-formado que chega ao leite é maior (Kay et al., 2004). A outra rota de produção de CLA no leite se dá quando ocorre elevação da biohidrogenação incompleta do ácido linoléico a ácido esteárico $\left(\mathrm{C}_{18: 0}\right)$ no rúmen, provocando elevação do ácido vacênico $\left(\mathrm{C}_{18: 1 t 11}\right)$, intermediário no processo de biohidrogenação no rúmen, que após absorção no trato gastro-intestinal servirá de substrato para a produção de CLA na glândula mamária através da enzima $\Delta^{9}$-desaturase (Palmquist, 1993) 
Tabela 11 - Teor de CLA (C $\left.\mathrm{C}_{18: 2 \mathrm{c} 9 t 11}\right)$ na gordura do leite de búfalas ao longo da lactação

\begin{tabular}{|c|c|c|c|c|c|c|c|c|}
\hline \multirow[t]{2}{*}{ Faz. } & \multicolumn{8}{|c|}{ Colheitas } \\
\hline & Abril & Maio & Junho & Julho & Agosto & Setembro & Outubro & Novembro \\
\hline 1 & $0,73 \pm 0,12^{1 b}$ & $1,07 \pm 0,10^{\mathrm{a}}$ & $1,23 \pm 0,2^{\mathrm{a}}$ & $1,12 \pm 0,10^{\mathrm{a}}$ & $1,33 \pm 0,13^{\mathrm{a}}$ & $1,10 \pm 0,20^{\mathrm{ab}}$ & $1,37 \pm 0,14^{\mathrm{a}}$ & $0,98 \pm 0,30^{\mathrm{ab}}$ \\
\hline 2 & $0,82 \pm 0,12^{\mathrm{bc}}$ & $0,72 \pm 0,10^{\mathrm{C}}$ & $1,10 \pm 0,13^{b}$ & $0,73 \pm 0,10^{\mathrm{c}}$ & $1,06 \pm 0,14^{b}$ & $1,74 \pm 0,20^{\mathrm{a}}$ & $1,05 \pm 0,14^{\mathrm{b}}$ & $1,32 \pm 0,24^{\mathrm{ab}}$ \\
\hline 3 & $1,43 \pm 0,14^{\mathrm{c}}$ & $1,59 \pm 0,10^{\mathrm{C}}$ & $1,68 \pm 0,15^{\mathrm{bc}}$ & $1,44 \pm 0,10^{\mathrm{c}}$ & $1,41 \pm 0,13^{\mathrm{c}}$ & $2,30 \pm 0,20^{\mathrm{a}}$ & $2,42 \pm 0,18^{\mathrm{a}}$ & $2,10 \pm 0,23^{\mathrm{ab}}$ \\
\hline 4 & $0,90 \pm 0,14^{\mathrm{bc}}$ & $0,86 \pm 0,10^{c}$ & $0,86 \pm 0,12^{\mathrm{c}}$ & $1,16 \pm 0,14^{\mathrm{ab}}$ & $1,2 \pm 0,12^{\mathrm{ab}}$ & $0,68 \pm 0,18^{\mathrm{c}}$ & $1,25 \pm 0,23^{\mathrm{abc}}$ & $1,57 \pm 0,26^{\mathrm{a}}$ \\
\hline 5 & $0,87 \pm, 0,12^{\mathrm{bc}}$ & $0,77 \pm 0,10^{\mathrm{c}}$ & $1,07 \pm 0,13^{b}$ & $1,10 \pm 0,10^{\mathrm{b}}$ & $1,10 \pm 0,13^{b}$ & $1,58 \pm, 0,20^{\mathrm{a}}$ & $1,57 \pm, 0,14^{\mathrm{a}}$ & $1,46 \pm 0,24^{\mathrm{ab}}$ \\
\hline
\end{tabular}

1 - erro padrão

Letras minúsculas distintas na mesma linha, representam médias diferentes $(\mathrm{P}<0,05)$ 
A biohidrogenação do ácido linoléico no rúmen varia entre $75 \%$ e 95\%. Quando a fonte deste ácido graxo é contínua (alimentação ad libitum) esta taxa é maior, diminuindo à medida que o número de refeições também diminui (Mattos \& Palmquist, 1977).

Na Fazenda 4, o maior teor médio de CLA no leite foi observado no mês de novembro (1,57\% na gordura do leite). O teor médio de CLA para as colheitas de outubro, agosto e julho foram 1,25\%, 1,23\% e 1,16\% da gordura do leite, respectivamente, não diferindo significativamente da colheita de novembro (Tabela 11). A menor média foi observada no mês de setembro $(0,68 \%$ da gordura do leite) não diferindo significativamente das médias dos meses de abril, maio e junho. Nesta fazenda, a dieta foi muito diversificada durante o período de colheita, houve troca mensal dos volumosos e o resíduo de cervejaria, que é uma importante fonte de ácido linoléico, esteve presente na dieta somente nos meses de abril, outubro e novembro. Nota-se que, com a chegada do período das águas (outubro e novembro) e a conseqüente melhoria da qualidade das pastagens e, com o retorno do fornecimento do resíduo de cervejaria à dieta, houve aumento do teor de CLA no leite. Como em bovinos, quando se aumenta a participação de forragens frescas na dieta ocorre elevação no teor de CLA no leite.

Na Fazenda 5 foi observado acréscimo ao longo da lactação, com os maiores teores médios nos meses de setembro, outubro e novembro, cujas médias foram 1,58\%, 1,57\% e 1,46\%, respectivamente. Este acréscimo era de se esperar, pois à medida que as pastagens participam da dieta há a tendência de aumento no teor de CLA no leite.

A Fazenda 3 destacou-se por ter sido observada a maior produção média de CLA na lactação, 1,77\% da gordura; a segunda maior média foi observada na Fazenda 5, 1,18\% da gordura do leite. As médias das demais fazendas foram: $1,14 \%, 1,10 \%$ e $1,02 \%$ de CLA na gordura do leite para as Fazendas 1, 4 e 2 , respectivamente. 
A comparação entre espécies não é apropriada nesse caso, mas, devido à escassez de dados relativos aos bubalinos, será feita breve comparação entre médias dos teores de CLA no leite entre bubalinos e bovinos.

As médias ao longo do ano do teor de CLA determinadas neste experimento, de acordo com as fazendas, variaram entre 1,02 e 1,77\% da gordura do leite, sendo superiores às médias publicadas por Dhiman et al. (1999) em bovinos, que obtiveram valores médios entre 0,64 e 0,98\% da gordura do leite. A média anual do teor de CLA no leite de bovinos, determinada por Lock \& Garnsworthy (2003) foi de 0,97\% dos ácidos graxos, chegando a $1,7 \%$, no verão. Portanto, os resultados foram inferiores aos determinados neste trabalho, em bubalinos, porém similar no verão. Kay et al. (2004) encontraram teor médio de CLA de 1,21\% dos ácidos graxos em bovinos em pastagens.

Na Itália, Fedele et al. (2001) compararam fazendas tradicionais em que as búfalas eram confinadas e fazendas orgânicas, em que as pastagens estavam presentes no sistema de produção animal. Os autores observaram diferença estatística entre os teores de CLA no leite entre os grupos. A maior média foi para o grupo de fazendas orgânicas (em pastejo), 0,63\% de CLA na gordura do leite e $0,39 \%$ da gordura do leite, para o grupo tradicional (confinadas). Na Índia, Aneja \& Murthy (1990) encontraram teores de CLA no leite de búfalas e de bovinos de 0,5 e 0,6\%, respectivamente. Os valores médios reportados pelos autores, em bubalinos, citados anteriormente, demonstram similaridades com os teores determinados em bovinos, assim parece não haver diferença entre as espécies, o que fortalece a idéia de que os teores de CLA no leite são mais influenciados pela dieta.

Diante destes resultados duas hipóteses podem ser abordadas. A primeira, é que os resultados nos teores de CLA aqui apresentados estão mais relacionados com a influência da dieta, especificamente com o resíduo de cervejaria, que pode ter proporcionado maior teor de ácido linoléico. O que provavelmente tenha ocasionado maiores concentrações de CLA pré-formado 
no leite. A Segunda hipótese está ligada à fatores intrínsecos à espécie, visto que os bubalinos ruminam aproximadamente $53 \%$ a mais que os bovinos, com isso, as partículas dos alimentos tornam-se mais finas no rúmen, consequentemente mais susceptíveis à colonização pelos microrganismos ruminais, além dos efeitos sobre o $\mathrm{pH}$ ruminal, provocado pela intensa salivação durante a remastigação (McSweeney et al., 1989). A segunda hipótese pode não ser determinante, pois os teores médios, mencionados na literatura internacional sobre bubalinos e bovinos não são diferentes quando submetidos a dietas semelhantes. Sendo assim, parece mais plausível a hipótese relacionada com o aporte de ácido linoléico no rúmen, que eleva a participação de CLA pré-formado no pool do CLA presente no leite.

Neste experimento, os resultados médios de CLA no leite obtidos diferiram dos publicados por Fedele et al. (2001) e por Aneja \& Murthy (1990), para bubalinos. As médias encontradas neste trabalho, mesmo a menor $(1,02$ \%) foi superior ao grupo de fazendas caracterizadas como orgânicas citadas por Fedele et al. (2001) (0,63\% de CLA na gordura do leite). No presente trabalho, a média geral para a Fazenda 3, foi de 1,77\% de CLA na gordura do leite, sendo três vezes superior aos resultados mencionado por Fedele et al. (2001) e por Aneja \& Murthy (1990).

\subsubsection{4 Ácidos graxos totais analisados através de análises multivariadas}

A análise de dados através do método multivariado de Análises de Componentes Principais (CP) é utilizada quando se tem grande número de variáveis. Este método tende explicar ao máximo a variação das variáveis originais analisadas através de algumas poucas variáveis não correlacionadas, denominadas de componentes principais.

Na Figura 6 é possível visualizar a distribuição espacial dos ácidos graxos no leite de búfalas (quadrantes A, B, C e D). 
O primeiro componente principal (CP1, eixo do "x") explica $37,4 \%$, e o segundo componente principal (CP2, eixo do "y"), 21,6\%, totalizando 59\% da explicação da variação total nos ácidos graxos do leite de búfalas (Figura 6).

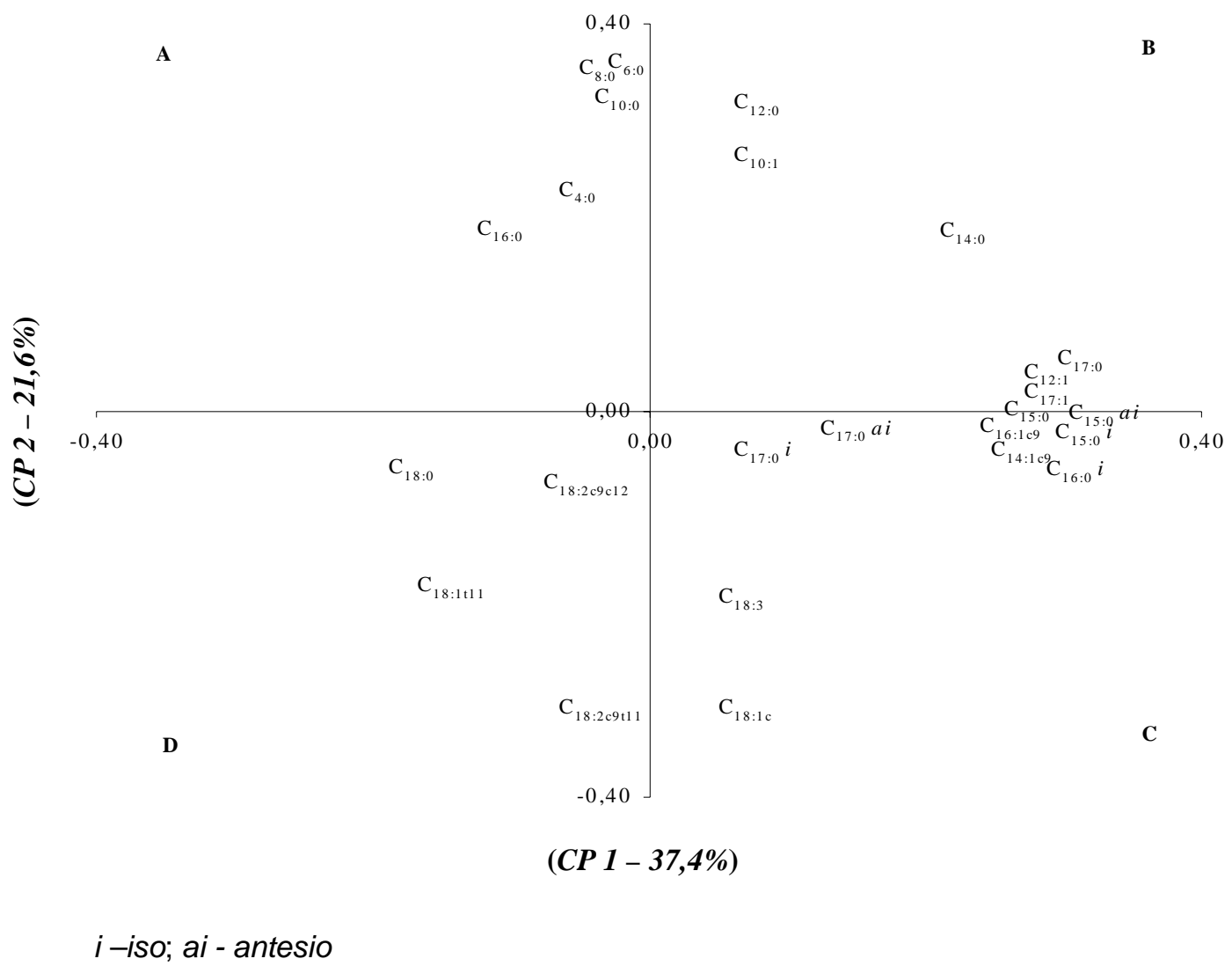

Figura 6. Relação entre os ácidos graxos no leite de búfalas, analisados através de análises multivariadas

Nos quadrantes A e B, encontram-se os ácidos graxos de cadeia curta e média, enquanto que os de cadeia longa situam-se nos quadrantes $C$ e $D$, caracterizando, assim, correlação negativa entre eles. Essa correlação negativa também foi observada por Fievez et al. (2003) em trabalho similar.

Os ácidos graxos $\mathrm{C}_{4: 0} ; \mathrm{C}_{6: 0} ; \mathrm{C}_{8: 0} ; \mathrm{C}_{10: 0}$ e $0 \mathrm{C}_{16: 0}$ (quadrante $\mathrm{A}$ ), apresentaram CP1 negativo, embora próximo de zero, e CP2 positivo. Dentre

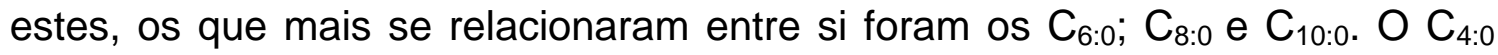
não está fortemente agrupado a estes ácidos graxos, mesmo sendo originado 
da mesma rota metabólica (síntese de novo). Segundo Palmquist (1993) o C4:0 por possuir estrutura de quatro átomos de carbono origina-se via ácido butírico (da dieta) ou através da condensação de unidades de acetil ( $\beta$-oxidação) o que determina menor variação em seu teor no leite.

Os ácidos graxos de cadeia ímpar e o $\mathrm{C}_{16: 0}$ iso no componente principal 1 (CP1) apresentaram valores positivos e próximos entre si (Figura 6). Apenas o $\mathrm{C}_{17: 0}$ iso apresentou valor próximo de zero, localizando-se mais distante do grupo. No componente principal 2 (CP2) os ácidos graxos com 15 e 17 átomos de carbono (iso e anteíso) e o $\mathrm{C}_{16: 0}$ iso apresentaram valores baixos e negativos, levando-os a ocupar o quadrante $\mathrm{B}$ e, em maior número o quadrante C (Figura 6). Deste grupo de ácidos graxos apenas os com 17 átomos de carbono ( $\mathrm{C}_{17: 0}$ iso e $\mathrm{C}_{17: 0}$ anteíso) não se agruparam fortemente, muito embora ocupem o mesmo quadrante $(C)$ que a maioria, os demais localizaram-se muito próximos um dos outros o que indica a origem microbiana comum.

$\mathrm{O}$ teor no leite do ácido graxo monoinsaturado $C_{14: 1 c 9}$, por não ser detectado na digesta, é o melhor indicador indireto da atividade da enzima $\Delta^{9}$ dessaturase presente na glândula mamária (Fievez et al., 2003). Outros ácidos graxos monoinsaturados, como o $\mathrm{C}_{16: 1 c 9}, \mathrm{C}_{18: 1 \mathrm{c9}}$ e o polinsaturado $\mathrm{C}_{18: 2 \mathrm{c} 9111}$ também têm sido utilizados como indicadores indiretos da atividade da enzima $\Delta^{9}$-dessaturase na glândula mamária.

Os ácidos graxos $\mathrm{C}_{14: 1 c 9}$ e $\mathrm{C}_{16: 1 c 9}$ apresentaram CP1 positivo (quadrante C), com baixos valores negativos no CP2, levando-os a ocupar quadrantes opostos a seus precursores, $\mathrm{C}_{14: 0}$ e $\mathrm{C}_{16: 0}$ (quadrantes $\mathrm{B}$ e $\mathrm{A}$ ), respectivamente. O $\mathrm{C}_{17: 1}$ encontra-se agrupado com o $\mathrm{C}_{14: 1 c 9}$ e $\mathrm{C}_{16: 1 \mathrm{c} 9}$. Dessa forma, os dados aqui apresentados corroboram a afirmativa de Fievez et al. (2003), que mencionaram que o $\mathrm{C}_{17: 1}$ possui também origem endógena, via ação da enzima $\Delta^{9}$-dessaturase na glândula mamária.

$\mathrm{O}$ agrupamento entre o $\mathrm{C}_{16: 0}$ iso, $\mathrm{C}_{15: 0}, \mathrm{C}_{15: 0}$ iso e o $\mathrm{C}_{15: 0}$ anteíso demonstra forte relacionamento entre si (quadrante $\mathrm{C}$ ), causado provavelmente pela origem comum (síntese microbiana ruminal). Observa-se também que os 
ácidos graxos de cadeia ímpar (Quadrantes B e C) e os ácidos graxos acima de 18 átomos de carbono (Quadrante D) possuem correlação negativa. Embora o $\mathrm{C}_{18: 1 c 9}$ e o $\mathrm{C}_{18: 3}$ estejam no mesmo quadrante que a maioria dos ácidos graxos de cadeia ímpar (C), sua localização espacial é distante dos ácidos graxos de cadeia ímpar, implicando, assim, no fato de que dietas que provoquem elevação no teor de ácidos graxos com mais de 18 átomos de carbono no leite, reduzam o teor de ácidos graxos de cadeia ímpar, provavelmente por afetar negativamente a população microbiana do rúmen.

Embora não tão pronunciada quanto aos valores encontrados por Fievez et al. (2003), a correlação negativa entre os ácidos graxos com 18 átomos de carbono e dos ácidos graxos monoinsaturados (Figura 6) pode ser resultado da inibição parcial da atividade da enzima $\Delta^{9}$-dessaturase pelos ácidos graxos de cadeia longa, que pode ser provocada, de acordo com Chilliard et al. (2000), pela ingestão de ácidos graxos polinsaturados, visto que o resíduo de cervejaria é rico em ácidos graxos polinsaturados.

No CP1, o CLA ( $\left.\mathrm{C}_{18: 2 \mathrm{2ct11}}\right)$ apresentou valor negativo, no entanto, próximo a zero. $\mathrm{O}_{18: 1111}$ (ácido vacênico) teve o mesmo comportamento, porém com valores negativos mais distantes de zero. No CP2, tanto o CLA como o ácido vacênico apresentaram valores negativos, no entanto, o CLA apresentou valor mais negativo, dessa forma, ambos ocuparam o mesmo quadrante (D), mas dispersos. A correlação entre estes ácidos graxos, obtida neste trabalho, foi positiva $(0,58)$, porém menor que a encontrada por Fievez et al. (2003) que foi de 0,80. A possível causa dessa menor correlação entre estes dois ácidos graxos no leite pode ter sido a elevada ingestão de ácido linoléico, via resíduo de cervejaria (média de $48 \%$ de ácido linoléico) que pode ter provocado aumento do escape do CLA sintetizado no rúmen (rota 2, Figura 7). Isto elevaria sua absorção, com conseqüente elevação de seu teor no leite, determinando menor contribuição da via endógena na produção de CLA, corroborando os dados de Kay et al. (2004). Pode também ter ocorrido aumento na produção de 
$\mathrm{C}_{18: 1 t 11}$ no rúmen (rota 1 , Figura 7 ) com conseqüente aumento da síntese endógena de CLA.

Segundo Fievez et al. (2003) o teor de CLA no leite depende mais do aporte de ácido vacênico na glândula mamária do que da atividade da $\Delta^{9}$ dessaturase, ou seja, quanto mais $\mathrm{C}_{18: 1111}$ chega à glândula mamária maior será a produção de CLA no leite, obviamente, até o limite de saturação da atividade desta enzima. No entanto, é importante lembrar que segundo Kay et al. (2004), sob determinadas dietas, o teor de CLA no leite varia mais em função do teor de ácido linoléico na dieta do que do aporte de ácido vacênico na glândula mamária.

\subsubsection{5 Ácidos graxos totais}

Os ácidos graxos identificados nas análises e de maior participação no leite de búfalas (média da lactação) em ordem decrescente, foram o $\mathrm{C}_{16: 0}$; $\mathrm{C}_{18: 1 c 9} ; \mathrm{C}_{18: 0}$ e o $\mathrm{C}_{14: 0}$ (Tabela 12). Esses também são os de maior participação no leite de bovinos de acordo com várias publicações (Palmquist et al., 1993; Jensen, 2002; Lock \& Garnsworthy, 2003).

Os teores médios detectados neste estudo, para o $\mathrm{C}_{14: 0}$, variaram entre 5,96 e $8,85 \%$ do total de ácidos graxos identificados. Estes teores foram menores que os encontrados por Lock \& Garnsworthy (2003) em trabalho similar a este, em que foi observada a média dos ácidos graxos ao longo da lactação em bovinos. Estes autores encontraram média de 10,7\%, sendo inferior aos valores publicados por Palmquist et al. (1993) e Jensen (2002), cujas médias foram 12,0\% e 13,0\%, respectivamente. Em bubalinos, Fedele et al. (2001) comparando fazendas orgânicas e tradicionais, na Itália, encontraram variação na média do $\mathrm{C}_{14: 0}$ entre 11,7 e $12,8 \%$, superiores aos resultados obtidos no presente experimento. Nas avaliações entre fazendas, destaca-se a Fazenda 3 , cuja média para o $\mathrm{C}_{14: 0}$ foi de $5,96 \%$, inferior às médias das demais fazendas avaliadas. 
Tabela 12 - Percentual médio de ácidos graxos presentes no leite de búfalas

\begin{tabular}{|c|c|c|c|c|c|}
\hline Ácidos graxos & Faz. 1 & Faz. 2 & Faz. 3 & Faz. 4 & Faz. 5 \\
\hline$C_{4 \cdot 0}$ & 3.77 & 3,87 & $\begin{array}{l}\% \\
3.77\end{array}$ & 407 & 396 \\
\hline $\mathrm{C}_{6: 0}$ & 2,04 & 1,95 & 1,36 & 1,73 & 1,74 \\
\hline$C_{8: 0}$ & 0,82 & 0,75 & 0,43 & 0,66 & 0,59 \\
\hline$C_{10: 0}$ & 1,53 & 1,46 & 0,80 & 1,27 & 1,28 \\
\hline$C_{10: 1}$ & 0,08 & 0,09 & 0,05 & 0,08 & 0,05 \\
\hline $\mathrm{C}_{12: 0}$ & 1,87 & 1,75 & 1,15 & 1,63 & 1,46 \\
\hline $\mathrm{C}_{12: 1}$ & 0,12 & 0,10 & 0,07 & 0,12 & 0,07 \\
\hline $\mathrm{C}_{14: 0}$ & 8,42 & 8,42 & 5,96 & 8,85 & 7,53 \\
\hline $\mathrm{C}_{14: 1 \mathrm{c} 9}$ & 0,53 & 0,54 & 0,38 & 0,78 & 0,48 \\
\hline $\mathrm{C}_{15: 0}$ iso & 0,27 & 0,28 & 0,31 & 0,48 & 0,33 \\
\hline $\mathrm{C}_{15: 0}$ anteiso & 0,47 & 0,47 & 0,49 & 0,67 & 0,47 \\
\hline $\mathrm{C}_{15: 0}$ & 1,06 & 1,03 & 1,06 & 1,17 & 0,98 \\
\hline $\mathrm{C}_{17: 0}$ iso & 0,34 & 0,31 & 0,49 & 0,49 & 0,42 \\
\hline $\mathrm{C}_{17: 0}$ anteiso & 0,18 & 0,16 & 0,22 & 0,32 & 0,21 \\
\hline $\mathrm{C}_{17: 0}$ & 0,50 & 0,47 & 0,62 & 0,73 & 0,54 \\
\hline$C_{17: 1}$ & 0,16 & 0,14 & 0,21 & 0,38 & 0,18 \\
\hline $\mathrm{C}_{16: 0}$ iso & 0,21 & 0,23 & 0,21 & 0,30 & 0,22 \\
\hline $\mathrm{C}_{16: 0}$ & 28,7 & 29,2 & 25,3 & 32,4 & 28,4 \\
\hline $\mathrm{C}_{16: 1 \mathrm{c} 9}$ & 1,42 & 1,49 & 1,43 & 2,04 & 1,45 \\
\hline $\mathrm{C}_{18: 0}$ & 11,13 & 11,32 & 13,44 & 7,86 & 11,73 \\
\hline $\mathrm{C}_{18: 1 \mathrm{t} 11}$ & 3,09 & 2,85 & 5,08 & 2,08 & 3,58 \\
\hline $\mathrm{C}_{18: 1 \mathrm{c} 9}$ & 20,6 & 20,7 & 25,1 & 21,2 & 21,7 \\
\hline $\mathrm{C}_{18: 1 \mathrm{c} 11}$ & 0,81 & 0,78 & 0,73 & 0,85 & 0,96 \\
\hline$C_{18: 1 c 12}$ & 0,27 & 0,25 & 0,19 & 0,14 & 0,28 \\
\hline $\mathrm{C}_{18: 1 \mathrm{t1} 16}$ & 0,21 & 0,18 & 0,31 & 0,14 & 0,20 \\
\hline $\mathrm{C}_{18 \mathrm{2} 2 \mathrm{t11} \mathrm{c} 15}$ & 0,18 & 0,16 & 0,20 & 0,37 & 0,23 \\
\hline $\mathrm{C}_{18 \mathrm{2} 2 \mathrm{c} 9 \mathrm{c} 12}$ & 1,70 & 1,78 & 1,77 & 1,53 & 1,71 \\
\hline $\mathrm{C}_{18: 3 \mathrm{c} 9 \mathrm{c} 12 \mathrm{c} 15}$ & 0,29 & 0,29 & 0,40 & 0,40 & 0,32 \\
\hline $\mathrm{C}_{18: 2 \mathrm{c} 9 t 11}(\mathrm{CLA})$ & 1,14 & 1,02 & 1,77 & 1,10 & 1,18 \\
\hline $\mathrm{C}_{18: 2 \mathrm{t} 10 \mathrm{t} 12}$ & 0,004 & 0,005 & 0,007 & 0,038 & 0,004 \\
\hline \multicolumn{6}{|l|}{ Cadeias } \\
\hline$<16 \mathrm{C}$ & 19,16 & 18,80 & 13,93 & 19,07 & 17,20 \\
\hline $16 \mathrm{C}$ & 30,34 & 30,95 & 26,99 & 34,81 & 30,08 \\
\hline $18 \mathrm{C}$ ou mais & 38,96 & 39,05 & 48,70 & 34,21 & 41,76 \\
\hline Ímpar & 3,29 & 2,84 & 3,30 & 1,03 & 3,05 \\
\hline
\end{tabular}

O teor médio observado do $\mathrm{C}_{16: 0}$, neste trabalho, variou entre $25,36 \%$ e $32,48 \%$ (Tabela 12). A média observada por Lock \& Garnsworthy (2003), em bovinos, foi de $18,70 \%$, portanto, inferiores a todas as médias aqui publicadas. 
Os valores obtidos por Lock \& Garnsworthy (2003) chamam a atenção, pois a média observada por estes autores também foi inferior às determinadas por Palmquist et al. (1993) e Jensen (2002) em bovinos, cujos valores foram $29,87 \%$ e $30,70 \%$, respectivamente. A média na Fazenda 1 , foi inferior às médias publicadas por Palmquist et al. (1993) e Jensen (2002). Nas Fazendas 1,2 e 5 os resultados médios encontrados foram similares aos publicados por Palmquist et al. (1993) e inferiores às médias publicadas por Jensen (2002), contudo, somente o resultado obtido na Fazenda 4 foi superior as médias mencionadas por esses autores.

Em bubalinos, Fedele et al. (2001) obtiveram teor do ácido palmítico $\left(\mathrm{C}_{16: 0}\right)$ entre $32,9 \%$ e $34,4 \%$. Estas médias foram superiores às determinadas em todos as fazendas do presente estudo, com exceção da Fazenda 4 que apresentou valor similar $(32,48 \%)$.

Alguns ácidos graxos como o $\mathrm{C}_{12: 0}, \mathrm{C}_{14: 0}$ e $\mathrm{C}_{16: 0}$ presentes no leite, estão relacionados à problemas cardiovasculares (Lock \& Garnsworthy, 2003). A diminuição do teor desses ácidos graxos tem sido almejada no intuito de melhorar a imagem, junto a opinião pública, dos produtos de origem animal. Os resultados encontrados para o conjunto destes ácidos graxos, neste trabalho, variaram entre $32,47 \%$ e $42,96 \%$ (Tabela 12), em que a Fazenda 3 apresentou a menor média, enquanto a maior média foi determinada para a Fazenda 4. Palmquist et al. (1993) e Jensen (2002) encontraram médias, em bovinos, de 47,5 e $46,9 \%$, respectivamente, superiores aos resultados aqui publicados. Lock \& Garnsworthy (2003) obtiveram média de 33,6\% para o mesmo conjunto de ácidos graxos em bovinos. Dentre as fazendas avaliadas nesse trabalho, apenas a Fazenda 3 apresentou média inferior à publicada por Lock \& Garnsworthy (2003), provavelmente, devido ao maior teor de ácidos graxos com cadeia carbônica acima que 18 átomos observada nessa fazenda.

Os resultados para o conjunto de ácidos graxos hiper-colesterolêmicos $\left(\mathrm{C}_{12: 0}, \mathrm{C}_{14: 0}\right.$ e $\left.\mathrm{C}_{16: 0}\right)$ observados neste trabalho de forma geral, são inferiores aos reportados em estudos com leite bovino. 
$\mathrm{O}$ teor médio de $\mathrm{C}_{18: 0}$ encontrado no leite de búfalas neste trabalho, variou entre $7,86 \%$ e $13,44 \%$. Estas médias foram inferiores aos relatados por Lock \& Garnsworthy (2003), que foi de 14,7\%. Palmquist et al. (1993) e Jensen (2002) em seus trabalhos obtiveram valor de $9,0 \%$ e $9,7 \%$, respectivamente, valores esses inferiores aos obtidos no presente experimento (Tabela 12 Fazendas 1, 2, 3 e 5). A exceção foi a Fazenda 4 cuja média foi inferior aos resultados desses autores. Em bubalinos, Fedele et al. (2001) encontraram média de 12,6\% para o $\mathrm{C}_{18: 0}$, dessa forma, apenas a Fazenda 4 apresentou média inferior a esta, as restantes foram similares.

O teor de CLA ( $\left.\mathrm{C}_{18: 2 c 9 t 11}\right)$ no leite foi mais elevado na Fazenda $3(1,77 \%)$, que nas demais fazendas. Dessa maneira, parece haver ligação entre as respostas obtidas para o $\mathrm{C}_{18: 0}, \mathrm{C}_{18: 1111}$ e CLA, todos envolvidos no processo de biohidrogenação ruminal. $\mathrm{Na}$ Tabela 12, pode-se observar que os teores do $\mathrm{C}_{18: 1111}$ e do $\mathrm{C}_{18: 0}$ também foram mais elevados na Fazenda 3 do que no restante, também, nota-se que o teor de ácido linoléico foi similar as demais fazendas, implicando assim, em biohidrogenação, desse ácido graxo, semelhante entre as fazendas. Dessa forma, o maior teor desses ácidos graxos $\left(\mathrm{C}_{18: 0}, \mathrm{C}_{18: 1111}\right.$ e CLA) parece estar relacionado ao provável maior aporte de ácido linoléico dietético na Fazenda 3 , seja pelo maior teor de extrato etéreo no resíduo de cervejaria, seja pelo maior fornecimento desse alimento.

$O$ teor médio de $C_{18: 1 c 9}$ observado na Fazenda 3 foi superior aos resultados obtidos por Lock \& Garnsworthy (2003), que foi de $23,6 \%$, as médias das demais fazendas foram inferiores à publicada por estes autores. A média publicada por Jensen (2002) foi menor que as encontradas, em todas as fazendas, neste trabalho. Em búfalos, Fedele et al. (2001) determinaram média entre 21,7 e 23,4\% para o $\mathrm{C}_{18: 1 c 9}$. Estes resultados são inferiores ao encontrado na Fazenda 3 e similar aos encontrados nas demais fazendas.

A dieta influencia pouco os teores do $\mathrm{C}_{18: 1 c 9}$ no leite, devido aos baixos teores observados nos alimentos. De acordo com Chilliard et al. (2000) cerca de $40,0 \%$ do $C_{18: 0}$ que chega à glândula mamária é dessaturado pela $\Delta^{9}$ - 
desaturase transformando-se em $\mathrm{C}_{18: 1 \mathrm{c} 9}$, assim, o teor de $\mathrm{C}_{18: 1 c 9}$ parece estar ligado à um maior teor de ácidos graxos polinsaturados biohidrogenados completamente no rúmen com posterior dessaturação na glândula mamária, via enzima $\Delta^{9}$-desaturase.

O ácido linoléico dietético está intimamente relacionado com produção de CLA no leite de ruminantes. A quantidade ingerida é, em geral, mais elevada que a secretada no leite em função do processo de biohidrogenação desse ácido graxo ocorrido no rúmen. A taxa de biohidrogenação ruminal do ácido linoléico atinge valores entre 75 e 95\% (Mattos \& Palmquist, 1977; Bickerstaffe et al., 1972), logo, é de se esperar que os valores encontrados no leite sejam baixos, como os observados neste trabalho, confirmando, assim, elevada biohidrogenação ruminal desse ácido graxo no rúmen, visto que, provavelmente, a ingestão dietética deste ácido graxo foi maior que a quantidade secretada no leite.

Foram observadas diferenças entre os resultados do ácido linoléico apresentados na literatura consultada com os obtidos no presente experimento. Nesse estudo, o teor médio do ácido linoléico variou entre 1,53\% e 1,78\%. Lock \& Garnsworthy (2003) e Jensen (2002) encontraram média anual de 3,1\%, em bovinos. Fedele et al. (2001), em bubalinos, encontraram valores variando entre 1,7 e $2,2 \%$, similares aos aqui apresentados.

$\mathrm{O}$ ácido linolênico $\left(\mathrm{C}_{18: 3}\right)$, que também sofre biohidrogenação ruminal, foi detectado no leite, nesse estudo, em percentual menor que o ingerido. $\mathrm{O}$ teor médio no leite variou entre $0,29 \%$ e $0,40 \%$, as maiores médias foram observadas nas Fazendas 3 e $4(0,40 \%)$ e nas Fazendas 1,2 e 5 as médias apresentadas foram 0,29\%, 0,29\% e 0,32\%, respectivamente. As Fazendas 3 e 4 apresentaram valor ligeiramente inferior ao publicado por Fedele et al. (2001), em bubalinos $(0,46 \%)$. Em bovinos a pasto Kay et al. (2004) constataram teor médio de ácido linolênico no leite de 0,60\%.

Em ruminantes, a correlação entre os ácidos graxos de cadeia curta e média com os de cadeia longa é negativa. Isso ocorre devido a ação dos ácidos 
graxos de cadeia longa dietéticos sobre a síntese de novo, rota metabólica pela qual se originam os ácidos graxos de 4 a 14 átomos de carbono e parte do $\mathrm{C}_{16: 0}$ (Palmquist et al., 1993).

A média dos ácidos graxos com 18 átomos de carbono, neste estudo, variou entre 34,21 e 48,70\% (Tabela 12). O maior teor foi verificado na Fazenda $3(48,70 \%)$ e demais fazendas apresentaram os seguintes teores médios $41,76 \%, 39,05 \%, 38,96 \%$ e 34,21\%, para as Fazendas 5, 2, 1 e 4, respectivamente. Na mesma Tabela 12, é possível observar as diferentes respostas para cada ácido graxo de cadeia curta e média. Observa-se que apenas o ácido butírico $\left(\mathrm{C}_{4: 0}\right)$ não apresentou mudanças de acordo com a fazenda, apesar da média da Fazenda 5 ser levemente superior às demais fazendas. Diversos autores não observaram variação no teor de $\mathrm{C}_{4: 0}$, sob dietas com níveis crescentes de fonte de ácidos graxos de cadeia longa, apesar de serem observadas mudanças nos demais ácidos graxos originados da síntese de novo (Handle \& Kennely, 1983; Kennely \& Lhorasani, 1992).

A síntese de $C_{4: 0}$ não sofre grandes variações com a elevação do teor de ácidos graxos de cadeia longa na dieta. Isso se deve aos seus precursores, $\beta$ hidroxibutirato, que contribui com aproximadamente metade da produção deste ácido graxo e com a condensação de unidades acetil ( $\beta$-oxidação, via malonilCoA) outra importante fonte de ácido butírico (Palmquist et al., 1993).

\subsection{Atividade da enzima $\Delta^{9}$-dessaturase}

A atividade da enzima $\Delta^{9}$-dessaturase na glândula mamária é medida indiretamente pela relação existente entre alguns ácidos graxos presentes no leite. Dentre essas relações, a que melhor afere esta atividade é a relação entre o ácido miristoléico e o mirístico $\left(\mathrm{C}_{14: 1 \mathrm{cc}} / \mathrm{C}_{14: 0}\right)$, devido ao fato de o $\mathrm{C}_{14: 1 \mathrm{c} 9}$ apresentar teores elevados no leite, enquanto na digesta sua concentração é baixa ou elemento traço (Lock \& Garnsworthy, 2003; Fievez et al., 2003). 
Tabela 13 - Aferição indireta da atividade da enzima $\Delta^{9}$-dessaturase na glândula mamária de bubalinos (relações entre os ácidos graxos)

\begin{tabular}{lccccc}
\hline Relações & Faz. 1 & Faz. 2 & Faz. 3 & Faz. 4 & Faz. 5 \\
\hline $\mathrm{C}_{14: 1 c \mathrm{c}} / \mathrm{C}_{14: 0}$ & 0,064 & 0,065 & 0,062 & 0,092 & 0,065 \\
$\mathrm{C}_{16: 1 \mathrm{co}} / \mathrm{C}_{16: 0}$ & 0,050 & 0,051 & 0,056 & 0,063 & 0,051 \\
$\mathrm{C}_{17: 1} / \mathrm{C}_{17: 0}$ & 0,32 & 0,30 & 0,33 & 0,48 & 0,31 \\
$\mathrm{C}_{18: 1 \mathrm{co}} / \mathrm{C}_{18: 0}$ & 1,96 & 1,94 & 1,98 & 2,78 & 2,00 \\
$\mathrm{C}_{18: 2 c 911} / \mathrm{C}_{18: 1111}$ & 0,32 & 0,30 & 0,33 & 0,48 & 0,31 \\
\hline
\end{tabular}

Lock \& Garnsworthy (2003) em revisão sobre a atividade da enzima $\Delta^{9}$ dessaturase encontraram, na literatura, valores da relação $C_{14: 1 c 9} / C_{14: 0}$ variando entre 0,060 e 0,114; e valor médio 0,062. Os resultados apresentados na Tabela 13, são similares aos valores publicados Lock \& Garnsworthy (2003) e Fievez et al. (2003).

No caso das fazendas onde resíduo foi incluído na dieta dos animais, o maior aporte de CLA (cis9, trans11) pode ter inibido sua formação a partir do seu precursor, refletindo no menor índice de dessaturase apresentado na Tabela 13. Esta suposta inibição da $\Delta^{9}$-dessaturase é consistente com as maiores relações entre os demais produtos e substratos desta enzima.

A relação $C_{16: 1 c 9} / C_{16: 0}$ foi menor em todas as fazendas ao valor médio publicado por Lock \& Garnsworthy (2003) que foi 0,079. A relação $C_{17: 1} / C_{17: 0}$ variou entre 0,30 e 0,48, destacando-se a Fazenda $4 \mathrm{com}$ a maior relação. Em todas as fazendas a relação $\mathrm{C}_{18: 1 c 9} / \mathrm{C}_{18: 0}$ foi maior que a observada por Lock \& Garnsworthy (2003) cuja média foi 1,525 , enquanto a relação $C_{18: 2 c 9 t 11} / C_{18: 1111}$ foi similar aos resultados publicados por estes autores $(0,304)$, com exceção da Fazenda 4 que foi superior.

Dentre todas as fazendas estudadas, a Fazenda 4 apresentou as maiores relações entre os ácidos graxos (Tabela 13). Dessa forma, estes resultados sugerem ter havido maior atividade, ou maior contribuição da enzima $\Delta^{9}$-dessaturase na glândula mamária no teor destes ácidos graxos.

Parece contraditório, mas a Fazenda 4 foi a que produziu menor teor de CLA no leite de búfalas (Tabela 11) mas também, foi nesta fazenda onde a atividade da 
$\Delta^{9}$-dessaturase foi maior (Tabela 13). Dito isto, é necessário lembrar que, de acordo com Kay et al. (2004), a contribuição da $\Delta^{9}$-dessaturase, no pool de ácidos graxos dessaturados na glândula mamária, em animais a pasto é maior do que em animais confinados. Também é importante lembrar que os animais da Fazenda 4 estiveram a maior parte do período de colheita exclusivamente a pasto. Portanto, parece prudente associar essa resposta a atividade da enzima $\Delta^{9}$-dessaturase em função do regime alimentar em que os animais estiveram submetidos. Dessa forma, os dados aqui discutidos, parecem corroborar os dados de Kay et al. (2004) que mencionam que a contribuição no total de CLA no leite produzido endogenamente via $\Delta^{9}$-dessaturase torna-se maior em animais submetidos a pastejo. Fato que pode ser observado na Tabela 13, em que pelas relações existentes a atividade da $\Delta^{9}$-dessaturase foi maior na Fazenda 4, por apresentar ao longo da lactação, dieta com baixa participação de resíduo de cervejaria (fonte de ácido linoléico) e maior proporção de pastagens e silagem de milho e pasto (fonte de ácido linolênico).

A quantidade ingerida de ácido linoléico parece influenciar a atividade da $\Delta^{9}$-dessaturase em animais submetidos a pastejo (Kay et al., 2004). Parece que elevadas ingestões de ácido linoléico diminuem a contribuição da $\Delta^{9}$ dessaturase no total produzido de CLA (Bessa et al., 2000), talvez, não por inibição mas por fazer chegar, à glândula mamária, mais CLA pré-formado. Assim, a Figura 2 deve ser observada sob a ótica de animais a pasto, porém em animais submetidos a dieta em que o ácido linoléico está presente em teores maiores que os encontrados nas pastagens, como é o caso do resíduo de cervejaria, a mesma deve ser adequada, enfatizando-se a rota de produção de CLA no leite via ácido linoléico como se observa na Figura 7. Dessa forma, a seta tracejada (rota 2) indica a rota principal da produção de CLA no leite quando a dieta é rica em ácido linoléico, que passa assim, a contribuir de forma mais intensa com o pool de CLA no leite. 

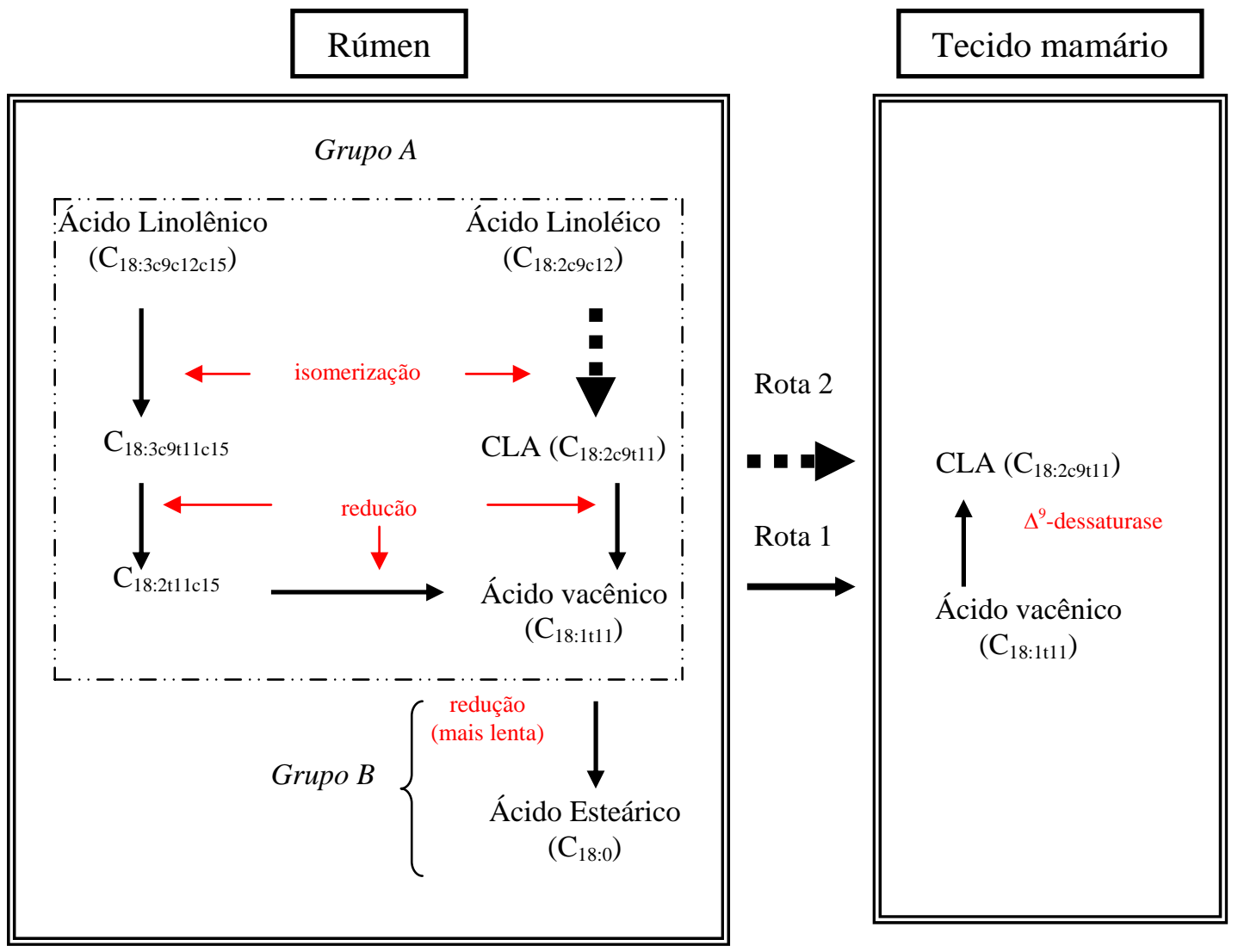

Figura 7. Representação da biohidrogenação ruminal dos ácidos linoléico e linolênico e produção de CLA no tecido mamário em dieta com elevado teor de ácido linoléico (Fonte: adaptado de Bauman, 2002)

De acordo com os resultados apresentados no presente experimento foram observados maiores teores de gordura, proteína e sólidos totais em leite de búfalas quando comparados aos valores obtidos por Tronco (2003) em bovinos. Estas respostas estão, provavelmente, ligadas às diferenças entre as espécies. Quanto ao teor de lactose (5\%), este se apresentou similar ao observados em bovinos por Tronco (2004), cujo valor foi 4,9\% no leite. Ao que parece, este efeito está relacionado à regulação da pressão osmótica do leite exercida pela lactose na glândula mamária. O teor de $\mathrm{N}$ uréico apresentou oscilações durante a lactação devido ao manejo nutricional inadequado, assim como foi superior, ao longo da lactação, ao recomendado como ideal para 
bovinos de leite por Jonker et al. (1998) e inferior aos dados publicados por Bovera et al. (2001) e Campanille et al. (1998) em bubaliinos.

O teor de CLA no leite obtido neste experimento foi superior aos resultados observados na literatura consultada, tanto em bovinos como em bubalinos. Obviamente, estes resultados foram obtidos em condições distintas. Como o teor de CLA no leite sofre influência da dieta fornecida, pesquisas comparativas entre bovinos e bubalinos com dietas iguais, são necessárias para que sejam respondidos alguns questionamentos, como a possibilidade da existência de diferenças entre essas espécies. Assim como testar as influências dos níveis de resíduo de cervejaria sobre a composição do leite. 


\section{CONCLUSÕES}

Os teores de gordura e proteína do leite de búfalas se elevaram ao longo da lactação; o teor de lactose acompanhou a curva de lactação, enquanto o teor de $\mathrm{N}$ uréico variou ao longo da lactação.

À medida em que a participação das pastagens na dieta aumentou, o teor de CLA no leite se elevou.

A B. ruziziensis apresentou maior teor dos ácidos graxos linoléico e linolênico do que $a$. decumbens no inverno e verão.

O resíduo de cervejaria possui elevados teores de ácido linoléico e possivelmente elevou o teor de CLA no leite de búfalos.

Houve grande variação individual no teor de CLA no leite de bubalinos, com maior variação nos animais em pastagens.

Os maiores teores de CLA no leite de búfalas foram observados nos sistemas a pasto com suplementação de resíduo de cervejaria. No verão o teor de CLA no leite de bubalinos nos rebanhos a pasto, foi mais elevado.

A metodologia de Análise de Componentes Principais indicou correlação positiva entre os ácidos graxos de cadeia ímpar e de cadeia ramificada e correlação negativa entre os ácidos graxos de cadeia longa com os ácidos graxos de cadeia curta, média, ímpar e ramificada.

Observou-se diminuição no teor de ácidos graxos hiper-colesterolêmicos à medida que houve elevação do teor de ácidos graxos de cadeia longa no leite.

A atividade da enzima $\Delta^{9}$-dessaturase, medida indiretamente, foi maior na fazenda em que a dieta dos animais, ao longo do ano, foi pasto. 
ANEXOS 
Anexo A - Parâmetros produtivos avaliados entre as fazendas estudadas

\begin{tabular}{cccc}
\hline Faz. & Produção $(\mathrm{kg})$ & $\begin{array}{c}\text { Produção média } \\
(\mathrm{kg} / \text { dia) }\end{array}$ & $\begin{array}{c}\text { Duração } \\
\text { (dias) }\end{array}$ \\
\cline { 2 - 2 } & Lactação & & \\
\hline 1 & $1.930 \pm 570$ & $7,9 \pm 2,5$ & $242 \pm 39$ \\
2 & $2.402 \pm 418$ & $9,5 \pm 1,5$ & $254 \pm 28$ \\
3 & $1.513 \pm 448$ & $6,5 \pm 1,3$ & $232 \pm 51$ \\
4 & $1.423 \pm 360$ & $5,8 \pm 1,2$ & $246 \pm 45$ \\
5 & $2.955 \pm 692$ & $11,0 \pm 3,2$ & $285 \pm 45$ \\
\hline
\end{tabular}




\section{REFERÊNCIAS BIBLIOGRÁFICAS}

ANEJA, R. P.; MURTHI,T. N. Conjugated linoleic acid contents of indian curds and ghee. Indian Dairy Science, n. 43, v. 2, 1990, p. 231-238.

BAER, R. J. Producción y utilizacción de leche de vaca y productos com ácidos grasos insaturados incorporados. In: PHILLIPS, C. J. C. Avances de la ciencia de la producción lechera. Zaragoza: Ed. Acríbia, 1996. cap. 12, p. 253-268.

BAUMAN, D.E. Regulation of nutrient partitioning during lactation: homeostasis and homeorhesis revisited. In: Ruminant Physiology: Digestion, Metabolism and Growth, and Reproduction, New York: PJ Conje, 2000. p.311-327.

BAUMAN, D. E. Conjugated linoleic acid and milk fat synthesis in dairy cows. In: INTERNATIONAL CONFERENCE ON CONJUGATED LINOLEIC ACID, 1, Alesund, 2001. Proceedings, p. 24.

BAUMAN, D. E. Conjugated linoleic acid (CLA) and milk fat: a good news story. In: ANNAUL ARIZONA DAIRY PRODUCTION CONFERENCE, 1._2003. http://animal.cals.arizona.edu/azdp/index/php (25 mar 2003).

BAUMAN, D. E.; KELLY, M. Conjugated linoleic acid: a potent anticarcinogenic found in milk fat. In: ANNUAL PROTIVA SCIENCE SYMPOSIUM, 2. Ithaca, 1997. Proceedings, Ithaca: Cornel University, 1997. $n / p$.

BAUMAN D. E.; GRIINARI, J. M. Nutritional regulation of milk fat synthesis. Annual of Review Nutrition, v. 23, p. 203-227, 2003. 
BAUMAN, D. E.; BAUMGARD, L. H.; CORL, B. A. et al. Biosynthesis of conjugated linoleic acid in ruminants. In: AMERICAN SOCIETY OF ANIMAL SCIENCE. Ithaca, 1999. Proceedings, Ithaca: Cornel University, 1999. p. 115.

BAUMGARD, L.H.; SANGSTER, J. K.; BAUMAN, D. E. et al. Milk fat synthesis in dairy cows is progressively reduced by increasing supplemental amounts of trans-10, cis-12 conjugated linoleic acid (CLA). Journal of Nutrition, v.131, N. 6, p.1764-1769, 2001.

BESSA, R. J. B.; SANTOS-SILVA, J.; RIBEIRO, J. M. R. et al. Reticulum-rumen biohidrogenation and the enrichment of ruminant edible products with linoleic acid conjugated isomers. Livestock Production Science, v. 63, p. 201-211, 2000.

BICKERSTAFFE, R.; NOAKES, D. E.; ANNISON, E. F. Quantitative aspects of fatty acid biohidrogenation, absorption, and transfer into milk fat in lactating goats, with special reference to the cis- and trans-isomers of octadecenote and linoleate. Biochemistry Journal, n. 130, p 607-617, 1972.

BOUGNOUX, P.; LAVILLONNIÈRE, F.; GARAUD, P. et al. CLA in experimental mammary tumors and in breast cancer. In: INTERNATIONAL CONFERENCE ON CONJUGATED LINOLEIC ACID, 1, Alesund, 2001. Proceedings, p. 9. BOVERA, F.; CUTRIGNELLI, M. I.; CALABRÒ, S. et al.. Influence of diet characteristics and productions levels on blood and milk urea concentrations in buffalo. In: WORLD BUFFALO CONGRESS, 6. Maracaibo, 2001. Proceedings. Maracaibo: Zulia University Tech Park, 2001. p. 506-511.

BYERS, F. M.; SCHELLING, G. T. Los lípidos en la nutrición de los rumiantes. In: $\mathrm{CHURCH}, \mathrm{D}$. C.. El rumiante, fisiologia digestiva e nutrición. Zaragoza: Acríbia, 1993. p. 339-356.

CAMPANILE, G.; DE FILLIPO, C.; DI PALO, R.; et al. Influence of dietary protein on urea levels in blood and milk of buffalo cows. Livestock Production Science, v. 55, p. 135-143, 1998. 
CHARACCO, C.; COlMENARES, 0.; BIRBE, B. et al. Non-genetic factors affecting productives characteristics in water buffalo. (Bubalus bubalis) in Colombia. In: WORLD BUFFALO CONGRESS, 6. Maracaibo, 2001. Proceedings. Maracaibo: Zulia University Tech Park, 2001, p. 315-323.

CHILLIARD Y.; FERLAY, A.; MANSBRIDGE, R. M. et al. Ruminant milk plasticity: nutritional control of saturated, polyunsaturated, trans and conjugated fatty acids. Annales Zootechnia, v. 49, p. 182-205, 2000.

CHOUINARD, P.Y.; CORNEAU, L.; BARBANO, D. M. Conjugated linoleic acids alter milk fatty acid composition and inhibit milk fat secretion in dairy cows. Journal of Nutrition, v.129, n. 8, p.1579-1584, 1999.

CHRISTIE, W. W.. Lipid analysis, 2. ed., Oxford: Elsevier. 1982a. 207 p.

CHRISTIE, W, W. A simple procedure for rapid transmethylation of glicerolipids and colesterol ester. Journal of Lipid Research, v. 23, p. 1072. 1982b.

CHRISTIE, W. W. The analysis of conjugated linoleic acid. In: INTERNATIONAL CONFERENCE ON CONJUGATED LINOLEIC ACID, 1 , Alesund, 2001. Proceedings, p. 9.

COOK, M. E. Conjugated linoleic acid (CLA) in growth and development. Mechanisms involving immunity and eicosanoids. In: INTERNATIONAL ANIMAL AGRICULTURE AND FOOD SCIENCE CONFERENCE, 2001. www.fass.org/fass01/pdfs/TableofContents.htm. (15 abr. 2002)

COSTA, E. O. da. Controle e prevenção de mastite em bubalinos. In: SIMPÓSIO PAULISTA DE BUBALINOCULTURA, 1., Jaboticabal, 1999. Jaboticabal: FUNEP, 1999. p. 68-83.

COSTA, J. M. B.; MATTOS, W. R. S.; BIONDE, R. et al. Composição química bromatológica do resíduo úmido de cervejaria. Boletim da Indústria Animal, v. 51, n.1, 21-26, jan./jun., 1994.

CUNNINGHAM, D.C.; HARRISON, L. Y.; SHULTZ, T. D. Proliferative response of normal human mammary and MCF-7 breast cancer cells to linoleic acid., conjugated linoleic acid and eicosanoid synthesis inhibitors in culture. Anticancer Research, v.17, p.197-204, 1997. 
DADO, R. G.; MERTENS, D. R.; SHOOK, G. E. Metabolizable energy and absorbed protein requirements for milk component production. Journal of Dairy Science, v. 76, p. 1575-1588, 1993.

DEMATAWEWA, C. M. B.; FUJII, C.; RUVANPATHIRANA, V. I. et al. Estimation of phenotypic and genetic parameters for 305-days adjust milk yield of buffaloes in Sri Lanka. In: WORLD BUFFALO CONGRESS, 6, Venezuela, 2001. Proceedings. Maracaibo: Zulia University Tech Park, 2001, p. 324-330.

DEWHURST, R. J.; SCOLLAN, N. D.; YOUELL, S. J. et al. Influence of species, cutting date and cutting interval on the fatty acid composition of grasses. Grass and Forage Science, v. 56, p. 68-74, 2001.

DEWHURST, R. J.; MOOBY, J. M.; SCOLLAN, N. D.; et al. Effects of a staygreen trait on the concentration and stability of fatty acid in perennial ryegrass. Grass and Forage Science, v. 57, p. 360-366, 2002.

DHIMAN, T. R.; HOOGENDIJK, B.; WALGENBACH, R. P.; et al. Feeding high oil corn to lactating dairy cows. Journal of Dairy Science, v. 79, suppl. 1, 1996, p. 136.

DHIMAN, T. R.; ANAND, G. R.; SATTER, L. D. et al. Conjugated linoleic acids content of milk from cows fed different diets. Journal of Dairy Science, v. 82, p. 2146-2156, 1999.

DIJKSTRA, J.; FRANCE, J.; DAVIES, D. R. Different mathematical approaches to estimating microbial protein supply in ruminants. Journal of Dairy Science, v. 81, n. 12, p. 3370-3384, 1998.

DOLL, R. The lessons of life: keynote address to the nutrition and cancer conference. Cancer Research, v.52, p.2024-2029, 1992.

DUARTE, J. M. C. Efeitos ambientais sobre a produção no dia do controle e características fisico-químicas do leite em um rebanho bubalino no estado de São Paulo, Brasil. Revista do Instituto de Laticínios "Cândido Tostes", v. 56, n. 322, p. 16-19, 2001. 
DURR, J.W. Determinação laboratorial dos componentes do leite. In: GONZALÉZ, F. H. D; DURR, J. W.; FONTANELI, R. S. Uso do leite para monitorar a nutrição e o metabolismo de vacas leiteiras. Porto Alegre: UFRGS, 2001. p. 23-29.

ELGERSMA, A.; ELLEN, G.; VAN DER HORST, H. et al. Comparison of the fatty acid composition of fresh and ensiled ryegrass (Lolium perenne L.), affected of cultivar and regrowth interval. Animal Feed Science and Technology, v. 108, p.191-205, 2003.

FARIA, M. H.; TONHATI, H.; CERÓN MUÑOZ, M. et al. Características fisicoquímicas do leite de búfalas ao longo da lactação. Revista do Instituto de Laticínios "Cândido Tostes", v. 57, n. 324, p. 3-7, 2002.

FEDELE, E.; IANNIBELLI, L.; MARZILLO, G. et al. Conjugated linoleic acid content in milk and mozzarela cheese from buffalo fed with organic and traditional diet. In: WORLD BUFFALO CONGRESS, 6. Maracaibo, 2001. Proceedings. Maracaibo: Zulia University Tech Park, 2001, p. 404-409.

FIEVEZ V.; VLAEMINCK, B.; DHANOA, M. S. et al. Use of principal components analysis to investigat the origin of heptadecenoic acid and conjugated linoleic acids in milk. Journal of Dairy Science, v. 86, p 10171053, 2003.

FRENCH, P.; STANTON, C.; LAWLESS, F. et al. Fatty acid composition, including conjugated linoleic acid, of intramuscular fat from steers offered grazed grass, grass silage, or concentrate-based diets. Journal of Animal Science, v.78, p. 2849-2855, 2000.

GAMA, M. A. S.; GRIINARI, J. M.; GARNSWORTH, P. C. et al. Concentration of cis-11C18:1 in milk is more closely related to milk fat depression (MFD) than trnas-10C $8: 1$ in cow fed fish oil. In: ANNUAL JOINT MEETING: ASASIADSA-PSA, St. Louis. 2004. Abstract, 
GONZALÉZ, F. H. D. Composição bioquímica do leite e hormônios da lactação. In: GONZALÉZ, F. H. D; DURR, J. W.; FONTANELI, R. S. Uso do leite para monitorar a nutrição e o metabolismo de vacas leiteiras. Porto Alegre: UFRGS, 2001. p. 5-22.

GRIINARI, J.M.; BAUMAN, D.E. Biosynthesis of conjugated linoleic acid and its incorporation into meat and milk in ruminants. In: M.P. Yurawecz, M.M. Mossoba, J.K.G. Kramer, M.W et al. Advances in conjugated inoleic acid research. Champain: American Oil Chemists Society Press, 1999, v.1, p.180-200.

GRIINARI, J. M.; DWYER, D. A.; McGUIRE, M. A. et al. Partially hydrogenated fatty acids and milk depression. Journal of Dairy Science, v. 79, Suppl. 1, p. 177, 1996.

GRIINARI, J. M.; DWYER, D. A.; McGUIRE, M. A. et al. Trans-octadecenoic acids and milk fat depression in lactating dairy cows. Journal of Dairy Science, v. 81, p. 1251-1261, 1998.

GRIINARI, J.M.; CORL, B. A.; LACY, S. H. et al. Conjugated linoleic acid is synthesized endogenously in lactating dairy cows by $\Delta 9$ desaturase. Journal of Nutrition, v.130, n. 9, p. 2285-2291, 2000.

GUILL-GUERRERO, J. L.; GARCIA MAROTO, F. F.; GIMÉNEZ GIMÉNEZ, A.. Fatty acid profile from forty-nine plant species that are potential new sources of gama-linolenic acid. Journal of the American Oil Chemists Societ, v.78, n. 7, p. 677-684, 2001.

HA, Y.L.; STORKSON, W; PARIAZ, M. W. Inhibition of benzo(a)pyreneinduced mouse forestomach neoplasia by conjugated dienoic derivatives of linoleic acid. Cancer Research, v. 50, p.1097-1101, 1990.

HARA, A.; RADIM, N. S. Lipid extraction of tissues with low toxicity solvent. Analytical Biochemistry, v. 90, p. 420-426, 1978.

HARWOOD, J. L. Plant acyl lipids: structure, distribution and analyses. In: STUMPF, P. K.; CONN, E. E. (Ed.) The biochemistry of plants. New York: Academic Press, 1980. v. 4, p. 1-55. 
HAWKE, J. C. Lipids. In: BUTLER, G. W.; BAILEY, R. W. Chemistry and biochemistry of herbage. New York: Academic Press, 1973. v. 1, p. 213264.

HOFFMANN, R. Componentes principais e análise fatorial. Piracicaba: ESALQ, 1999. 40p. (Série Didática, 90).

HOLMAN, R.T.; MAHFOUZ, M.M. Cis and trans octadecadienoic acids as precursors of polyunsaturated fatty acids. Progress Lipid Research v.20, p.151-156, 1980.

HOPKINS W. G. Introduction to plant physiology. New York: John Willey. 1995. $464 \mathrm{p}$.

HURLEY, W. L. Lactose synthesis. In: Lactation biology. http://classes.acess.uiuc.edu/AnSci308/lactosesynthesis.html (11 mar. 2003).

INSTITUTO AGRONÔMICO DE CAMPINAS. www.iac.sp.gov.br (12 jan. 2004).

IP, C. CLA and cancer prevention research. In: INTERNATIONAL CONFERENCE ON CONJUGATED LINOLEIC ACID, 1, Alesund, 2001 Proceedings, Norway, 2001, p. 8.

IP, C.; JIANG, C.; THOMPSON, H. J. et al. Retention of conjugated linoleic acid in the mammary gland is associated with tumor inhibition during the postinitiation phase of carcinogenesis. Carcinogenesis, v.18, p.755-759, 1997.

IP, C.; BANNI, S.; ANGIONI, E, et al. Conjugated linoleic acid-enriched butter fat alters mammary gland morphogenesis and reduces cancer risk in rats. Journal of Nutrition, v.129, p.2135-2142, 1999.

IP, C.; CHIN, S. F.; SCIMECA, J. A. et al. Mammary cancer prevetion by conjugated dienoic derivative of linoleic acid. Cancer Research, v. 51, p. 6118-6124, 1991.

INTERNATIONAL UNION OF PURE AND APPLIED CHEMISTRY Standard methods for the analysis of oils, fats and derivatives. 6, ed. Oxford: Pergamon Press, 1979. 170 p. 
JENSEN, R. G. The composition of bovine milk lipids: january 1995 to december 2000. Journal of Dairy Science, v.85, p. 295-350, 2002.

JONKER, J. S.; KOHN, R. A.; ERDMAN, R. A. Using urea nitrogen to predict nitrogen excretion and utilization efficiency in lactating dairy cows. Journal of Dairy Science, v.81, p. 2681-2692, 1998.

KAY, J. K.; MACLE, T. R.; AULDIST, M. J. et al. Endogenous synthesis of cis-9, trans-11 conjugated linoleic acid in dairy cows fed fresh pasture. Journal of Dairy Science, v. 87, p. 369-378, 2004.

KELLY, M. L.; BERRY, J. R.; DWYER, D. A. et al. Effect of dietary fatty acids sources on conjugated linoleic acid (CLA) levels in milk from lactating dairy cows. Journal Dairy Science, v. 80, Suppl. 1, p. 243, 1997

KELLY, M. L.; BERRY, J. E.; DWYER, J. M. et al. Dietary fatty acid sources affect conjugated linoleic acid concentrations in milk from lactating dairy cows. Journal of Nutrition, v.128, p.881-885, 1998.

KENNELY, J. J. The fatty acid composition of milk fat as influenced by feding oilseeds. Animal Feed Science Thechnology, v. 60, p. 137-152, 1996.

KOMARAGIRI, M.; V. S.; CASPER, D. P.; ERDMAN, R. A.. Factors affeting body tissue mobilizationa in early lactation dairy cows. 2 . Effect of dietary fat on mobilization of body fat and protein. Journal of Dairy Science, v. 81, p. 169-175, 1998.

LAWLESS, F; MURPHY, J, J.; HARRINGTON, D. et al. Elevation of conjugated cis-9, trans-11- octadecadiencoic acid in bovine milk because dietary supplementation. Journal Animal Science, v.81, p. 3259-3267, 1998.

LOCK, A. L.; GARNSWORTHY, P. C. Seasonal variation in milk conjugated linoleic acid and $\Delta^{9}$-desaturase activity in dairy cows. Livestock Production Science, v.79, p. 47-59, 2003.

LOOR, J. J.; HERBEIN, J.H. Exogenous conjugated linoleic acid isomers reduce bovine milk fat concentration and yield by inhibiting de novo fatty acid synthesis. Journal of Nutrition, v. 128, p.2411-2419, 1998. 
MATTOS, W. R. S.; PALMQUIST, D. L. Biohydorgenation and avaibility of linoleic acid in lactating cows. Journal of Nutrition, v. 107, p. 1755-1761, 1977.

McDONALD, P.; EDWARD, R. A.; GREENHALGH, J. E. D. Nutrición animal, 5. ed. Zaragoza: Acríbia, 1996. 576 p.

MCCLYMONT, G.L.; VALLANCE, S. Depression of blood glycerides and milk fat synthesis by glucose infusion. Proceeding of Nutrition Society, v.21, 1962.

McSWEENEY. C. S.; KENNEDY, P. M.; JOHN, A. Reticulo-ruminal motility in cattle (Bos indicus) and water buffaloes (Bubalus bubalis) fed a low quality roughage diet. Comparative and biochemistry and Physiology, n. 94, p. 635-638, 1989.

MESQUITA, A. J. de; TANEZINI, C. A.; FONTES, I. F. et al. Qualidade físicoquímica e microbiológica do leite cru bubalino. Goiânia: UFGO, 2001. 77 p.

MOHEDE, I.; ALBERS, R.; VAN DER WIELEN, R. et al. Imuno-modulation: CLA stimulates antigen specific antibody production in humans. In: INTERNATIONAL CONFERENCE ON CONJUGATED LINOLEIC ACID, 1, Alesund, 2001. Proceedings, p. 12.

NILSSON, I.; SUNDQUIST, M.; EINWALL, I. Variations in CLA content in milk. In: INTERNATIONAL CONFERENCE ON CONJUGATED LINOLEIC ACID, 1 Alesund, 2001. Proceedings, p. 48.

NOUSIAINEM, J.; SHINGFIELD, K. J.; HUHTANEN, P. Evaluation of milk urea nitrogen as a diagnostic of protein feeding. Journal of Dairy Science, v. 87, p. 386-398, 2004.

NUTRITIONAL RESEARCH COUNCIL. The water buffalo: new prospects for an under-utilised animal. Washington: National Academy Press, 1981. 117 p.

O'KELLY, J. C.; REICH, H. P. The fatty acid composition of tropical pastures. Journal of Agricultural Science, v. 86, p. 427-429, 1976. 
OKINE, E.; GOONEVARDENE, L. A.; MIR, Z. et al. Influence of canola oil on the fatty acid profile in goat milk. In: INTERNATIONAL CONFERENCE ON CONJUGATED LINOLEIC ACID, 1, Alesund, 2001. Proceedings, p. 50.

PALMQUIST, D. L.. Suplementação de lipídios para vacas em lactação. In: PEIXOTO, A. M.; MOURA, J. C.; FARIA, V. P. Nutrição de bovinos. conceitos básicos e aplicados. Piracicaba: FEALQ, 1993. p. 321-337.

PALMQUIST, D. L.; BEAULIEU, A. D.; BARBANO, D. M. Feed and animal factors influencing milk fat composition. Journal of Dairy Science, v. 76, p. 1753-1771, 1993.

PARIZA, M. V. Conjugated linoleic acid: unravelling the isomer paradox. In: INTERNATIONAL CONFERENCE ON CONJUGATED LINOLEIC ACID, 1, Alesund, 2001. Proceedings, p. 5.

PARIZA, M. W.; PARK, Y.; COOK, M. E. Mechanisms of action of conjugated linoleic acid: evidence and speculation. In: SOCIETY EXPERIMENTAL OF BIOLOGY MEDICINE, Proceedings. 2000. v. 223, p. 8-13.

PARODI, W. P. Milk fat components: possible chemopreventive agents for cancer and other diseases. Australian Journal of Dairy Technology, v.51, p.24-32, 1996.

PIREDDA, G.; ADDIS, M.; DI SALVO, R. et al. Effect of different gracing management on milk and cheese CLA content in dairy sheep. In: INTERNATIONAL CONFERENCE ON CONJUGATED LINOLEIC ACID, 1, Alesund, 2001. Proceedings, p. 53.

PRANDINI, A.; TERZANO, M.; FERRARI, B. et al. Season and ripening affect CLA content of ewe's milk and cheese. In: INTERNATIONAL CONFERENCE ON CONJUGATED LINOLEIC ACID, 1, Alesund, 2001. Proceedings, p. 54. RIEL, R. R. Physico-chemical characteristics of canadian milk fat. Unsaturated fatty acids. Journal of Dairy Science. v. 46, p. 102-106, 1963.

RODIGUEZ-RUIZ, J.; BELARBI, E.; SÁNCHEZ, J, L. G. et al. Rapid simultaneous lipid extraction and transesterification for fatty acid analyses. Biothechnology Technology, v. 12, n. 9, p. 689-691, 1998. 
ROSELER, D. K.; FERGSUN, J. D.; SNIFFEN, C, J. et al. Dietary protein degradability effect on plasma and milk urea nitrogen and milk nonprotein nitrogen in Holstein cows. Journal of Dairy Science, v.76, n. 2, p. 525-534, 1993.

SANTOS, F. L.; SILVA, M. T. C.; LANA, R. P. et al. Efeito da suplementação de lipídeos na ração sobre a produção de ácido linoléico conjugado (CLA) sobre a composição de gordura no leite. Revista Brasileira de Zootecnia, v. 30, n. 6, p. 1931-1938. 2001.

SAS INSTITUTE. SAS OnlineDoc/Version eight. http://www.smoo.ciagri.usp.br/sasdoc/sas.html/welcome.htm. (27 fev. 2004). SCHONBERG, S.; KROKAN, H. E. The inhibitory effect of conjugated dienoic derivatives (CLA) of linoleic acid on the growth of human tumor cell lines is in part due to increased lipid peroxidation. Anticancer Research, v.15, p.12411246, 1995.

StANTON, C.; NORGREN, M., ROSBERG, G. et al. Human intestinal isolates with ability to efficiently synthesise CLA. In: INTERNATIONAL CONFERENCE ON CONJUGATED LINOLEIC ACID, 1, Alesund, 2001. Proceedings, p. 17.

SUTTON, J.D. Altering milk composition by feedind. Journal of Dairy Science, v.72, n.10, p. 2801-2814, 1989.

TONHATI, H. Resultados do controle leiteiro em bubalinos. In: SIMPÓSIO PAULISTA DE BUBALINOCULTURA, 1. Jaboticabal, 1999. Jaboticabal: FUNEP, 1999. p. 90-109.

TONHATI, H.; TALARICO DIAS, L.; TEIXEIRA, R M. et al. Study of lactation persistence of buffaloes in Brazil. WORLD BUFFALO CONGRESS, 6, Maracaibo, 2001. Proceedings. Maracaibo: Zulia University Tech Park, 2001, p. 348-353.

TRONCO. V. M. Manual para inspeção da qualidade do leite. 2 ed. Santa Maria: Editora UFSM, 2003. 192 p. 
VAN SOEST, P. J. Nutritional ecology of the ruminant, 2 ed. Ithaca: Cornell University Press. 1994. 724 p.

VARGAS, O. L.. Como deve ser produzido e transportado o leite para consumo humano. In: CONGRESSO BRASILEIRO DE GADO DE LEITE, 2. Piracicaba, 1996. Piracicaba: FEALQ, 1996. p. 169-244.

VOET, D.; VOET, J. G.; PRATT, C. W. Fundamentos de bioquímica. Porto Alegre: Artmed, 2000, 931 p..

YOKOYAMA, M. T.; JOHNSON, K. A. Microbiología del rumen e intestino. In: CHURCH, D. C.. EL RUMIANTE, FISIOLOGIA DIGESTIVA E NUTRICIÓN. Zaragoza: Acríbia, 1993. p. 137-3158.

YURAWECZ, M. P.; KRAMAER, J. K. G.; MOSSOBA, M. M. et al. Analytical methodology for CLA. In: INTERNATIONAL CONFERENCE ON CONJUGATED LINOLEIC ACID, 1, Alesund, 2001. Proceedings, p. 14.

$\mathrm{ZU}, \mathrm{H} . \mathrm{X}$; SCHUT, H.A.J. Inhibition of 2-amino-3-methylimidazo (4,5-f) quinoline-DNA adduct formation in CDF1 mice by heat-altered derivatives of linoleic acid. Food Chemical Toxicology, v.30, p.9-16, 1992. 